Wetlands Regulatory Assistance Program

\title{
A Bibliography of Selected Literature on Indirect Impacts Associated with Clean Water Act Section 404 Permits
}

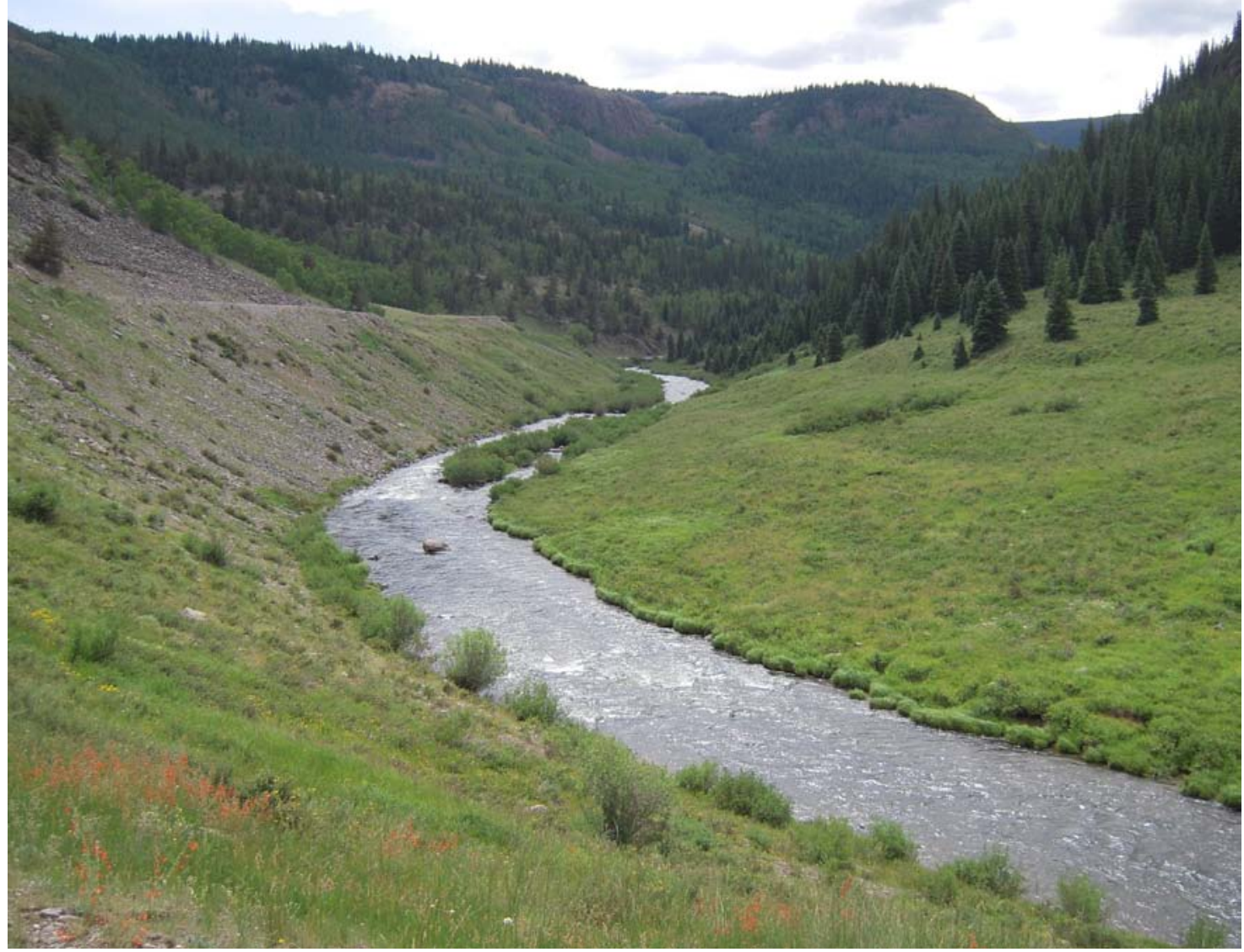




\section{A Bibliography of Selected Literature on Indirect Impacts Associated with Clean Water Act Section 404 Permits}

Timothy C. Wilder, William M. Ford, and Marie M. Perkins

Environmental Laboratory

U.S. Army Engineer Research and Development Center

3909 Halls Ferry Road

Vicksburg, MS 39180-6199

Final report

Approved for public release; distribution is unlimited. 


\begin{abstract}
This report summarizes a review of the scientific literature from the year 2000 to the present that characterizes indirect impacts associated with Clean Water Act Section 404 permits. Also of interest was literature from 2004 forward that addresses compensatory mitigation for impacts, particularly with respect to current policy.
\end{abstract}

Literature containing derivations of the search terms "Clean Water Act," "404," "temporary fill," "dredge and fill," "impact," "secondary impact," and "cumulative impact" in the title, keyword or abstract field(s) was selected. When these searches produced few results, the number of search terms was expanded. This series of searches returned in excess of 5,500 bibliographic records. Each record's abstract was then reviewed for relevance to the Corps of Engineer's 404 permitting program and assigned to at least one of 20 groups according to the focus of that particular study. A review for relevance and assignment to groups reduced the number of records to 1,252 (approximately $10 \%$ of which were assigned to more than one group).

DISCLAIMER: The contents of this report are not to be used for advertising, publication, or promotional purposes. Citation of trade names does not constitute an official endorsement or approval of the use of such commercial products. All product names and trademarks cited are the property of their respective owners. The findings of this report are not to be construed as an official Department of the Army position unless so designated by other authorized documents. 


\section{Contents}

Figures and Tables........................................................................................................................................

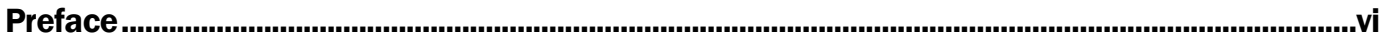

1 Introduction

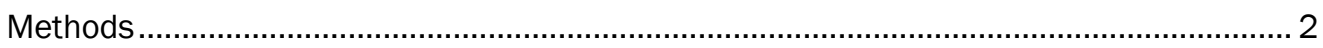

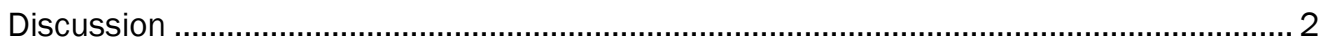

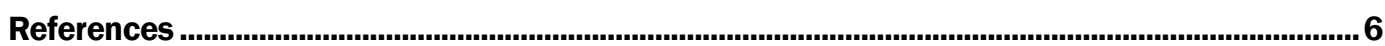

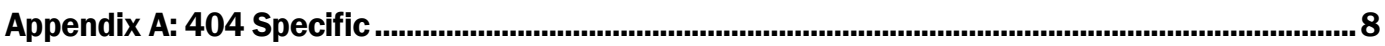

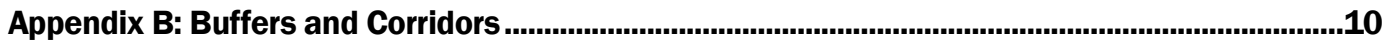

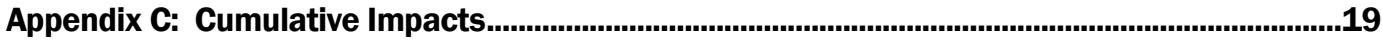

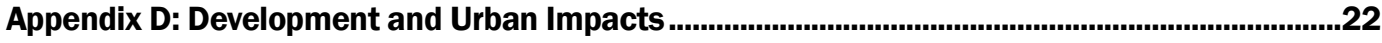

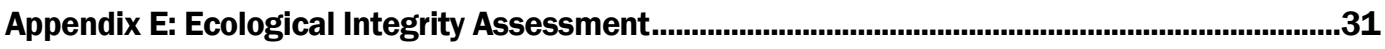

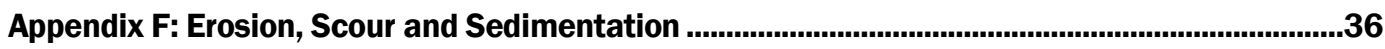

Appendix G: Mercury and Other Heavy Metals .......................................................................41

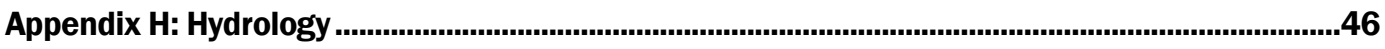

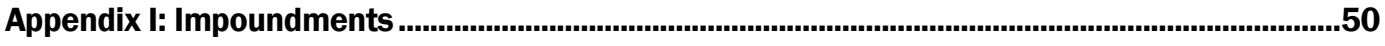

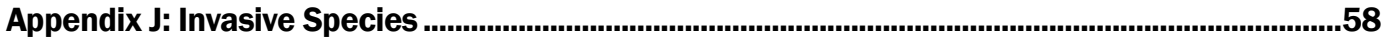

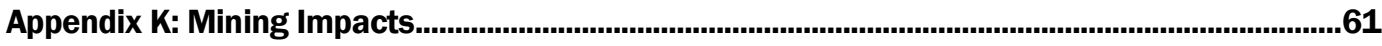

Appendix L: Powerlines and Pipelines...............................................................................66

Appendix M: Regulation, Policy, Mitigation and Restoration.....................................................69

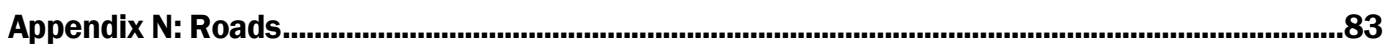

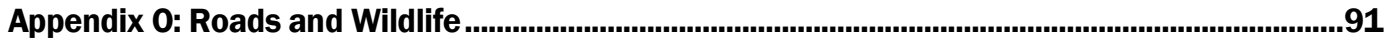

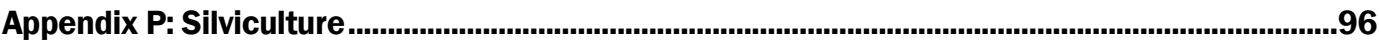

Appendix Q: Stream Channel Geometry and Stability........................................................100

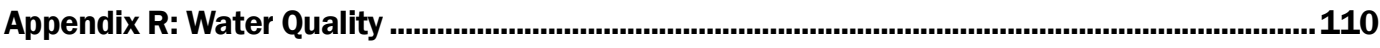

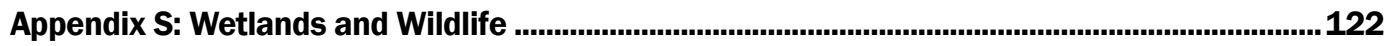


Appendix T: Wetland Mitigation Web Sites .

Report Documentation Page 


\section{Tables}

\section{Tables}

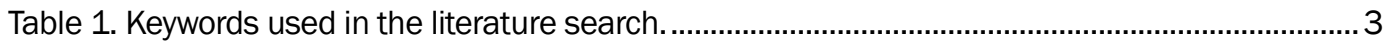

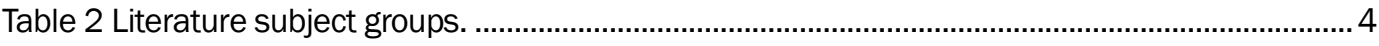




\section{Preface}

This work was conducted by the Environmental Laboratory (EL), U.S. Army Engineer Research and Development Center (ERDC), for the Corps of Engineers Wetlands Regulatory Assistance Program (WRAP). Timothy C. Wilder, William M. Ford, and Marie M. Perkins compiled this report and the WRAP Program Manager was Bob Lazor, EL.

This report was prepared under the general supervision of Morris Mauney, Chief, Wetlands and Coastal Ecology Branch, EL; Dr. Edmund Russo, Chief, Ecological Evaluation and Engineering Division, EL; and Dr. Beth Fleming, Director, EL.

COL Gary E. J ohnston was Commander and Executive Director of ERDC. Dr. J effery P. Holland was Director. 


\section{Introduction}

Section 404 of the Clean Water Act (CWA) directs the U.S. Army Corps of Engineers (COE) to administer a regulatory program for permitting the discharge of dredged or fill material in "waters of the United States." Successful applicants for 404 permits must demonstrate that impacts have been avoided, that unavoidable impacts have been minimized, and that adequate compensation will be provided for remaining impacts (U.S. Army Corps of Engineers and Environmental Protection Agency 1990).

This three-part sequence for review of compensatory mitigation has its roots in the beginnings of the Section 404 permitting program. Indeed, the first COE 404 regulations in 1973 contained language urging permit applicants to modify proposals to eliminate or mitigate damage to aquatic resources. The concept matured over several years, requiring revisions of COE and EPA 404 regulations. This process culminated in February 1990 with the signing of the "Memorandum of Agreement Between The Department of the Army and The Environmental Protection Agency: The Determination of Mitigation under the Clean Water Act Section 404(b)(1) Guidelines" (Hough and Robertson 2009).

The agencies and the public recognized cumulative and indirect impacts of discharged dredged and fill material into aquatic sites at the inception of the 404 program. Despite this, the focus of the 404 program has been on direct impacts for much of its history (Hirsch 1988). Among the most important reasons for this narrow focus was the time necessary to settle interpretation of relevant law, resolve jurisdictional issues, and develop administrative process (Hough and Robertson 2009). Difficulties inherent in assessing indirect and cumulative impacts over multiple temporal and spatial scales have also been a barrier to considering them in the context of the 404 program (Brody et al. 2008; Stein and Ambrose 2001; Swenson and Ambrose 2007).

The New England District, Corps of Engineers requested a review of the scientific literature from 2000 to the present that characterizes indirect impacts associated with CWA Section 404 permits. Also of interest was literature from 2004 forward that addresses compensatory mitigation for 
impacts, particularly with respect to current policy. This report is a compilation of the results of that literature review.

\section{Methods}

Literature selected contained derivations of the search terms "Clean Water Act," "404," "temporary fill," "dredge and fill," "impact," "secondary impact," "indirect impact," and "cumulative impact" in the title, keyword, or abstract field(s). When these searches produced few results, the number of search terms was expanded. Table 1 lists the two categories that most of the search terms used in subsequent searches fell under.

Searches using the keywords in Table 1 returned in excess of 5,500 bibliographic records. Each record's abstract was then reviewed for relevance to the COE's 404 permitting program and assigned to at least one of 20 groups according to the focus of that particular study. Table 2 lists the subject groupings that were used. Review for relevance and assignment to groups reduced the number of records to 1,252 (approximately 10\% of which were assigned to more than one group).

\section{Discussion}

Literature published after 2000 was found to contain relatively few studies that explicitly focused on documenting indirect or secondary impacts from a 404-permitted activity. The majority of those found were assigned to the "Cumulative Impacts" and "404 Specific" groups. The bulk of the remaining literature addresses impacts, though the author(s) may not have traced them to an activity that would ordinarily require a 404 permit. For example, a recent study conducted in Maryland and Pennsylvania documents current downstream effects of existing small impoundments on stream bed load and morphology and discusses implications to the stream in the event of their removal (Skalak, Pizzuto, and Hart 2009).

An exhaustive listing of the tremendous body of literature in some areas would have produced a great deal of duplication. Literature on wildlife, roads, road infrastructure, urbanization, water quality, wetland mitigation, and regulatory policy is extensive. Instead, studies were selected from across the United States that were judged to fully represent these subjects. Studies in the New England region were included preferentially, though a few citations of studies conducted overseas have been included when they illustrate some underlying ecological principle or mechanism that is 


\section{relevant to Section 404. Citations prior to 2000 that were believed to be especially useful were also retrieved.}

Table 1. Keywords used in the literature search.

\begin{tabular}{|c|c|c|}
\hline \multirow{2}{*}{$\begin{array}{l}\text { Pollutants and Effects } \\
\text { algae }\end{array}$} & \multicolumn{2}{|c|}{ Activities associated with Section 404 permits } \\
\hline & armoring & powerline \\
\hline bacteria & bank stabilization & pumping \\
\hline biological oxygen demand & berm & reservoir \\
\hline brush & boat launching ramp & retaining wall \\
\hline channel bed aggradation & borrow pit & riparian buffer \\
\hline channel incision & bridge & riprap \\
\hline channel widening & building & road \\
\hline chemical oxygen demand & clearing & road crossing \\
\hline chemicals & culvert & sewer line \\
\hline debris & dam & soil harvest \\
\hline erosion & development & soil mining \\
\hline eutrophication & dike & soil pit \\
\hline fertilizers & ditch & spoil \\
\hline flooding & ditches & stream channelization \\
\hline grass clippings & ditching & stream dredging \\
\hline insecticides & diversion & stream encapsulation \\
\hline lawn waste & drain & stream ford \\
\hline litter & drainage & stream relocation \\
\hline mass-wasting & easement & stream widening \\
\hline metals & fill & trail \\
\hline noise & filling & trenching \\
\hline nutrient enrichment & flume & vegetation removal \\
\hline nutrients & french drain & water diversion \\
\hline pesticides & gravel/sand dredging & waters supply intake \\
\hline ponding & gravel/sand harvest & water transfer \\
\hline scour & gravel/sand mining & water withdrawal \\
\hline sediment & green-tree reservoir & weir \\
\hline sedimentation & highway & wing wall \\
\hline soil compaction & impoundment & \\
\hline stream capture & irrigation & \\
\hline stream loss & levee & \\
\hline thermal & parking lot & \\
\hline trash & pipeline & \\
\hline woody debris & pond & \\
\hline
\end{tabular}


Table 2 Literature subject groups.

\begin{tabular}{|l|r|}
\hline Groups by subject and number of records found \\
\hline 404 Specific & 22 \\
\hline Buffers and Corridors & 100 \\
\hline Cumulative Impacts & 29 \\
\hline Development and Urban Impacts & 103 \\
\hline Ecological Integrity Assessment & 52 \\
\hline Erosion, Scour and Sedimentation & 44 \\
\hline Mercury and Other Heavy Metals & 49 \\
\hline Hydrology & 47 \\
\hline Impoundments & 92 \\
\hline Invasive Species & 27 \\
\hline Mining Impacts & 45 \\
\hline Powerlines and Pipelines & 25 \\
\hline Regulation, Policy, Mitigation and Restoration & 164 \\
\hline Roads & 88 \\
\hline Roads and Wildlife & 56 \\
\hline Silviculture & 36 \\
\hline Stream Channel Geometry and Stability & 115 \\
\hline Water Quality & 127 \\
\hline Wetlands and Wildlife & 65 \\
\hline Wetland Mitigation Web Sites & 25 \\
\hline
\end{tabular}

Literature on habitat alteration effects on wildlife is both voluminous and largely tangential to regulatory discussions. Still, for most species, responses to habitat change from secondary or direct impacts in the New England area are predictable based simply on an understanding of a particular species' life history and ecology.

Government documents and other "gray literature" are included in addition to peer-reviewed scientific literature, especially those containing comprehensive management recommendations for the New England region. Two such are the Metropolitan Conservation Alliance's "Forestry Habitat Management Guidelines for Vernal Pool Wildlife" (Calhoun and deMaynadier 2004) and the Wildlife Habitat Council's "A Guide to Managing Rights-of-Way for Wildlife Habitat" (Bonneau 2005). 
As with the wildlife literature, literature is listed in which the relevance to 404 permitting may not be due primarily to impacts that arise from a permitted activity. Included are studies that describe methods to assess impacts (Brooks, Wardrop, and Cole 2006; Cohen et al. 2005), aspects of compensatory mitigation or ecosystem restoration (BenDor and Brozovic 2007; Brooks et al. 2005; Craig et al. 2008) and studies that may inform regulatory personnel about potential unintended or unforeseen consequences; some negative; such as the methylization of mercury in wetlands (Rumbold and Fink 2006; Watras et al. 2005); and some positive; such as nutrient uptake as an unintended benefit of stream restoration (Bukaveckas 2007).

The literature was reviewed for studies describing mitigation policy at the state and local level. This literature was found to be fairly limited and is generally aimed at the effectiveness of regulatory programs (Morgan and Roberts 2003). For this area of review, a subject group has been included containing web sites of state and local authorities where mitigation regulations and policies are described. Two web sites may prove particularly useful. One is the "Wetlands Information Resource Center" (National Center for Manufacturing Sciences 2010) located at http:// www.envcap.org/statetools/swift/swift.html. This web site contains summaries and links to each of the 50 states' web sites pertaining to wetland regulations and policy. The other is "Clean Water Act Section 404 Mitigation Guidance Directory" (National Oceanic and Atmospheric Administration Fisheries Service 2009) located at http:// www.mitigationactionplan.gov/links.html.

Bibliographies for each of the 20 groups listed in Table 2 are included as separate appendices (Appendices A-T). 


\section{References}

BenDor, T., and N. Brozovic. 2007. Determinants of spatial and temporal patterns in compensatory wetland mitigation. Environmental Management 40 (3):349-364.

Bonneau, J . 2005. A guide to managing rights-of-ways for wildlife habitat. Silver Spring, MD: Wildlife Habitat Council.

Brody, S. D., S. E. Davis, W. E. Highfield, and S. P. Bernhardt. 2008. A spatial-temporal analysis of section 404 wetland permitting in Texas and Florida: Thirteen years of impact along the coast. Wetlands 28 (1):107-116.

Brooks, R. P., D. H. Wardrop, and C. A. Cole. 2006. Inventorying and monitoring wetland condition and restoration potential on a watershed basis with examples from Spring Creek Watershed, Pennsylvania, USA. Environmental Management 38 (4):673-687.

Brooks, R. P., D. H. Wardrop, C. A. Cole, and D. A. Campbell. 2005. Are we purveyors of wetland homogeneity? A model of degradation and restoration to improve wetland mitigation performance. Ecological Engineering 24 (4):331-340.

Bukaveckas, P. A. 2007. Effects of channel restoration on water velocity, transient storage, and nutrient uptake in a channelized stream. Environmental Science and Technology 41 (5):1570-1576.

Calhoun, A.J.K., and P. deMaynadier. 2004. Forestry habitat management guidelines for vernal pool wildlife. In MCA Technical Paper No. 6. Bronx, New York: Metropolitan Conservation Alliance, Wildlife Conservation Society.

Cohen, M. J ., C. R. Lane, K. C. Reiss, J . A. Surdick, E. Bardi, and M. T. Brown. 2005. Vegetation based classification trees for rapid assessment of isolated wetland condition. Ecological Indicators 5 (3):189-206.

Craig, L. S., M. A. Palmer, D. C. Richardson, S. Filoso, E. S. Bernhardt, B. P. Bledsoe, M. W. Doyle, P. M. Groffman, B. A. Hassett, S. S. Kaushal, P. M. Mayer, S. M. Smith, and P. R. Wilcock. 2008. Stream restoration strategies for reducing river nitrogen loads. Frontiers in Ecology and the Environment 6 (10):529-538.

Hirsch, Allan. 1988. Regulatory context for cumulative impact research. Environmental Management 12 (5):715-723.

Hough, P., and M. Robertson. 2009. Mitigation under Section 404 of the Clean Water Act: Where it comes from, what it means. Wetlands Ecology and Management 17 (1):15-33.

Morgan, K. L., and T. H. Roberts. 2003. Characterization of wetland mitigation projects in Tennessee, USA. Wetlands 23 (1):65-69.

National Center for Manufacturing Sciences. 2010. Wetlands Information Resource Locator. Available from http:// www.envcap.org/ statetools/ swift/ swift.html. 
National Oceanic and Atmospheric Administration Fisheries Service. 2009. National Wetlands Action Plan, Clean Water Act Section 404 Mitigation Guidance Directory [2009]. Available from http:// www.mitigationactionplan.gov/links.html.

Rumbold, D. G., and L. E. Fink. 2006. Extreme spatial variability and unprecedented methylmercury concentrations within a constructed wetland. Environmental Monitoring and Assessment 112 (1-3):115-135.

Skalak, K., J . Pizzuto, and D. D. Hart. 2009. Influence of small dams on downstream channel characteristics in Pennsylvania and Maryland: Implications for the longterm geomorphic effects of dam removal. J ournal of the American Water Resources Association 45 (1):97-109.

Stein, E. D., and R. F. Ambrose. 2001. Landscape-scale analysis and management of cumulative impacts to riparian ecosystems: Past, present, and future. J ournal of the American Water Resources Association 37 (6):1597-1614.

Swenson, D. P., and R. F. Ambrose. 2007. A spatial analysis of cumulative habitat loss in Southern California under the Clean Water Act Section 404 program. Landscape and Urban Planning 82 (1-2):41-55.

U.S. Army Corps of Engineers, and Environmental Protection Agency. 1990.

Memorandum of Agreement Between The Department of the Army and The Environmental Protection Agency: The Determination of Mitigation under the Clean Water Act Section 404(b)(1) Guidelines. Washington, DC.

Watras, C. J., K. A. Morrison, A. Kent, N. Price, O. Regnell, C. Eckley, H. Hintelmann, and T. Hubacher. 2005. Sources of methylmercury to a wetland-dominated lake in northern Wisconsin. Environmental Science and Technology 39 (13):4747-4758. 


\section{Appendix A: 404 Specific}

Brody, S. D., S. E. Davis, W. E. Highfield, and S. P. Bernhardt. 2008. A spatial-temporal analysis of section 404 wetland permitting in Texas and Florida: Thirteen years of impact along the coast. Wetlands 28 (1):107-116.

Brody, S. D., W. E. Highfield, H. C. Ryu, and L. Spanel-Weber. 2007. Examining the relationship between wetland alteration and watershed flooding in Texas and Florida. Natural Hazards 40 (2):413-428. http:// www.springerlink.com/ content/ 052637724628240u/ fulltext.pdf

General Accounting Office (GAO). 1988. Wetlands: The Corps of Engineers' Administration of the Section 404 Program. GAO/RCED-88-110. Washington, DC: GAO. http://archive.gao.gov/d16t6/ 136780.pdf

Hirsch, A. 1988. Regulatory context for cumulative impact research. Environmental Management 12 (5):715-723. http:// dx.doi.org/ 10.1007/ BF01867548

Hough, P., and M. Robertson. 2009. Mitigation under Section 404 of the Clean Water Act: Where it comes from, what it means. Wetlands Ecology and Management 17 (1):15-33. http:// dx.doi.org/ 10.1007/ s11273-008-9093-7

Kentula, M., J . Sifneos, J . Good, M. Rylko, and K. Kunz. 1992. Trends and patterns in Section 404 permitting requiring compensatory mitigation in Oregon and Washington, USA. Environmental Management 16 (1):109-119. http:/ / dx.doi.org/ 10.1007/ BF02393913

National Center for Manufacturing Sciences. Wetlands Information Resource Locator. http:// www.envcap.org/statetools/ swift/ swift.html.

Owen, C., and H. J acobs. 1992. Wetland protection as land-use planning: The impact of Section 404 in Wisconsin, USA. Environmental Management 16 (3):345-353. http:// dx.doi.org/ 10.1007/ BF02400073

Rittenhouse, T. A. G., and R. D. Semlitsch. 2007. Distribution of amphibians in terrestrial habitat surrounding wetlands. Wetlands 27 (1):153-161.

Robertson, M., and N. Hayden. 2008. Evaluation of a market in wetland credits: Entrepreneurial wetland banking in Chicago. Conservation Biology 22 (3):636646.

Sifneos, J ., E. Cake, and M. Kentula. 1992. Effects of Section 404 permitting on freshwater wetlands in Louisiana, Alabama, and Mississippi. Wetlands 12 (1):2836. http:/ / dx.doi.org/ 10.1007/ BF03160541

Siragusa, K. S. Integrating a watershed approach into Clean Water Act Section 404, wetland and stream compensatory mitigation lessons learned and recommendations for Georgia. http:// purl.galileo.usg.edu/ uga\%5Fetd/ siragusa\%5Fkelly\%5F200805\%5Fms. [Internet Resource; Archival Material Date of Entry: 20090824] 2008 
Stein, E. D., and R. E. Ambrose. 1998. Cumulative impacts of Section 404 Clean Water Act permitting on the riparian habitat of the Santa Margarita, California watershed. Wetlands 18 (3):393-408.

Stein, E. D., and R. F. Ambrose. 2001. Landscape-scale analysis and management of cumulative impacts to riparian ecosystems: Past, present, and future. J ournal of the American Water Resources Association 37 (6):1597-1614.

Steiner, F., S. Pieart, E. Cook, J . Rich, and V. Coltman. 1994. State wetlands and riparian area protection programs. Environmental Management 18 (2):183-201. http:/ / dx.doi.org/ 10.1007/BF02393761

Sudol, M. F., and R. F. Ambrose. 2002. The US Clean Water Act and habitat replacement: Evaluation of mitigation sites in Orange County, California, USA. Environmental Management 30 (5):727-734.

http:// www.springerlink.com/ content/ kle5g5f92434t9cf/ fulltext.pdf

Swenson, D. P., and R. F. Ambrose. 2007. A spatial analysis of cumulative habitat loss in Southern California under the Clean Water Act Section 404 program. Landscape and Urban Planning 82 (1-2):41-55.

http:// www.sciencedirect.com/science?_ob=ArticleURL\&_udi=B6V91-

4N7YFK3-

$2 \& \_$user $=930810 \& \_r d o c=1 \& \_\mathrm{fmt}=\& \_$orig $=$search\&_sort=d\&_docanchor $=\&$ vie $\mathrm{w}=\mathrm{c} \&$ a acct $=\mathrm{C} 000048423 \&$ version $=1 \&$ _ urlVersion $=0 \&$ \& userid $=930810 \& \mathrm{md} 5$ $=\mathrm{a} 9 \mathrm{adb} 4 \mathrm{~d} 99 \mathrm{~b} 5 f 5 f 69 \mathrm{ebe} 19 f 4160 \mathrm{fbb} 49 \mathrm{c}$

Thompson, J . W. J . N. S. S. 2008. The federal wetland permitting program avoidance and minimization requirements.

http:/ / www.elistore.org/reports_detail.asp?ID=11275\&topic=wetlands. [Internet Resource; Computer File Date of Entry: 20080409]. Washington, DC : Environmental Law Institute 2008 (accessed April 9 2008).

Torok, L., S. Lockwood, and D. Fanz. 1996. Review and comparison of wetland impacts and mitigation requirements between NewJ ersey, USA, Freshwater Wetlands Protection Act and Section 404 of the Clean Water Act. Environmental Management 20 (5):741-752. http: / / dx.doi.org/ 10.1007/BF01204145

U.S. Army Corps of Engineers, and U.S. Environmental Protection Agency. 1990. Memorandum of Agreement Between The Department of the Army and The Environmental Protection Agency: The Determination of Mitigation under the Clean Water Act Section 404(b)(1) Guidelines. Washington, DC: http:/ / www.usace.army.mil/ CECW/ Documents/ cecwo/ reg/mou/migrate.pdf

Wilkinson, J . 2009. In-lieu fee mitigation: Coming into compliance with the new Compensatory Mitigation Rule. Wetlands Ecology and Management 17 (1):5370. http:// www.springerlink.com/ content/y5538766x2551382/ fulltext.pdf

Williams, M., C. Hopkinson, E. Rastetter, J . Vallino, and L. Claessens. 2005. Relationships of land use and stream solute concentrations in the Ipswich River basin, northeastern Massachusetts. Water, Air, and Soil Pollution 161(1-4):5574. http:// dx.doi.org/ 10.1007/ s11270-005-2830-0 


\section{Appendix B: Buffers and Corridors}

Alexander, R. B., E. W. Boyer, R. A. Smith, G. E. Schwarz, and R. B. Moore. 2007. The role of headwater streams in downstream water quality. J ournal of the American Water Resources Association 43 (1):41-59. http:// dx.doi.org/ 10.1111/j.17521688.2007.00005.x

Allen, S. B., J . P. Dwyer, D. C. Wallace, and E. A. Cook. 2003. Missouri River flood of 1993: Role of woody corridor width in levee protection. J ournal of the American Water Resources Association 39 (4):923-933.

Anbumozhi, V., J . Radhakrishnan, and E. Yamaji. 2005. Impact of riparian buffer zones on water quality and associated management considerations. Ecological Engineering 24 (5 SPEC. ISS.):517-523. http:// dx.doi.org/ 10.1016/j.ecoleng.2004.01.007

Anderson, P. D., D. J . Larson, and S. S. Chan. 2007. Riparian buffer and density management influences on microclimate of young headwater forests of western Oregon. Forest Science 53 (2):254-269.

Angier, J . T., and G. W. McCarty. 2008. Variations in base-flow nitrate flux in a firstorder stream and riparian zone. J ournal of the American Water Resources Association 44 (2):367-380. http:// dx.doi.org/ 10.1111/j.1752-1688.2007.00153.x

Angier, J . T., G. W. McCarty, and K. L. Prestegaard. 2005. Hydrology of a first-order riparian zone and stream, mid-Atlantic coastal plain, Maryland. J ournal of Hydrology 309 (1-4):149-166.

http:/ / www.sciencedirect.com/science?_ob=MImg\&_imagekey=B6V6C4F4NYHH-4-

R\&_cdi $=5811 \&$ user $=930810 \&$ orig $=$ search\&_coverDate $=07 \% 2 \mathrm{~F} 19 \% 2 \mathrm{~F} 2005 \&$ sk=996909998\&view=c\&wchp=dGLbVlWzSkWb\&md5=c9ed4791cc8e36df8a204aa1505030b7\&ie=/ sdarticle.pdf

Askins, R. A. 1994. Open corridors in a heavily forested landscape: Impact on shrubland and forest-interior birds. Wildlife Society Bulletin 22 (2):339-347. http:// www.jstor.org/ stable/ 3783267

Bakermans, M. H., and A. D. Rodewald. 2006. Scale-dependent habitat use of Acadian Flycatcher (Empidonax Virescens) in central Ohio. Auk 123 (2):368-382. CCC:000237442500007

Baldwin, R. F., A. J . K. Calhoun, and P. G. deMaynadier. 2006. Conservation planning for amphibian species with complex habitat requirements: A case study using movements and habitat selection of the Wood Frog Rana sylvatica. J ournal of Herpetology 40 (4):442-453. http:/ / falcon.cc.ukans.edu/ gpisani/ SSAR.html

Blanco-Canqui, H., C. J . Gantzer, S. H. Anderson, and E. E. Alberts. 2004. Grass barriers for reduced concentrated flow induced soil and nutrient loss. Soil Science Society of America J ournal 68 (6):1963-1972. 
Blanco-Canqui, H., C. J . Gantzer, S. H. Anderson, E. E. Alberts, and A. L. Thompson. 2004. Grass barrier and vegetative filter strip effectiveness in reducing runoff, sediment, nitrogen, and phosphorus loss. Soil Science Society of America J ournal 68 (5):1670-1678.

Bolger, D. T., T. A. Scott, and J . T. Rotenberry. 2001. Use of corridor-like landscape structures by bird and small mammal species. Biological Conservation 102 (2):213-224. http:// www.sciencedirect.com/ science/ article/ B6V5X-441N9148/2/a77d216e92b84a8d86a446b4c20bbdb7

Boyd, L. 2001. Wildlife use of wetland buffer zones and their protection under the Massachusetts Wetland Protection Act. University of Massachusetts.

Bub, B. R., D. J . Flaspohler, C. J . F. Huckins, and Giuliano. 2004. Riparian and upland breeding-bird assemblages along headwater streams in Michigan's Upper Peninsula. J ournal of Wildlife Management 68 (2):383-392. http:/ / dx.doi.org/ 10.2193/ 0022-541X(2004)068[0383:RAUBAA]2.0.CO; 2

Burton, M. L., L. J . Samuelson, and S. Pan. 2005. Riparian woody plant diversity and forest structure along an urban-rural gradient. Urban Ecosystems 8 (1):93-106. http:/ / dx.doi.org/ 10.1007/s11252-005-1421-6

Clausen, J . C., K. Guillard, C. M. Sigmund, and K. Martin Dors. 2000. Water quality changes from riparian buffer restoration in Connecticut. J ournal of Environmental Quality 29 (6):1751-1761.

Cobourn, J . 2006. How riparian ecosystems are protected at Lake Tahoe. J ournal of the American Water Resources Association 42 (1):35-43.

Conner, R. N., J . G. Dickson, J . H. Williamson, and B. Ortego. 2004. Width of Forest Streamside Zones and Breeding Bird Abundance in Eastern Texas. Southeastern Naturalist 3 (4):669-682. http:/ / dx.doi.org/ 10.1656/ 15287092(2004)003[0669:WOFSZA]2.0.CO; 2

Crawford, J . A., and R. D. Semlitsch. 2007. Estimation of core terrestrial habitat for stream-breeding salamanders and delineation of riparian buffers for protection of biodiversity. Conservation Biology 21 (1):152-158.

DeWalle, D. R. 2008. Guidelines for riparian vegetative shade restoration based upon a theoretical shaded-stream model. J ournal of the American Water Resources Association 44 (6):1373-1387. http:// dx.doi.org/ 10.1111/j.17521688.2008.00230.x

Diamond, J . M., D. W. Bressler, and V. B. Serveiss. 2002. Assessing relationships between human land uses and the decline of native mussels, fish, and macroinvertebrates in the Clinch and Powell River watershed, USA. Environmental Toxicology and Chemistry 21(6):1147-1155. http:// dx.doi.org/ 10.1897/ 1551-5028(2002)021<1147:ARBHLU>2.0.CO;2

Dodds, W. K., and R. M. Oakes. 2006. Controls on nutrients across a prairie stream watershed: Land use and riparian cover effects. Environmental Management 37 (5):634-646. http:// dx.doi.org/ 10.1007/ s00267-004-0072-3 
Dukes, M. D., and R. O. Evans. 2003. Riparian ecosystem management model: Hydrology performance and sensitivity in the North Carolina Middle Coastal Plain. Transactions of the American Society of Agricultural Engineers 46 (6):15671579.

Dukes, M. D., R. O. Evans, J. W. Gilliam, and S. H. Kunickis. 2002. Effect of riparian buffer width and vegetation type on shallow groundwater quality in the Middle Coastal Plain of North Carolina. Transactions of the American Society of Agricultural Engineers 45 (2):327-336.

Egan, R. S., and P. W. C. Paton. 2004. Within-pond parameters affecting oviposition by wood frogs and spotted salamanders. Wetlands 24 (1):1-13.

Evans, D. R., and J . E. Gates. 1997. Cowbird selection of breeding areas: The role of habitat and bird species abundance. The Wilson Bulletin 109 (3):470-480. http:// www.jstor.org/ stable/ 4163842

Fabos, J . G. 2004. Greenway planning in the United States: Its origins and recent case studies. Landscape and Urban Planning 68 (2-3):321-342. http:// dx.doi.org/ 10.1016/j.landurbplan.2003.07.003

Freeman, M. C., C. M. Pringle, and C. R. J ackson. 2007. Hydrologic connectivity and the contribution of stream headwaters to ecological integrity at regional scales. J ournal of the American Water Resources Association 43 (1):5-14. http:// dx.doi.org/ 10.1111/j.1752-1688.2007.00002.x

Freeman, R. E., and R. O. Ray. 2001. Landscape ecology practice by small scale river conservation groups. Landscape and Urban Planning 56 (3-4):171-184. http:/ / dx.doi.org/ 10.1016/ S0169-2046(01)00181-5

Gamble, L. R., K. McGarigal, C. L. J enkins, and B. C. Timm. 2006. Limitations of regulated "buffer zones" for the conservation of marbled salamanders. Wetlands 26 (2):298-306.

Goetz, S. J . 2006. Remote sensing of riparian buffers: Past progress and future prospects. J ournal of the American Water Resources Association 42 (1):133-143.

Goetz, S. J ., R. K. Wright, A. J . Smith, E. Zinecker, and E. Schaub. 2003. IKONOS imagery for resource management: Tree cover, impervious surfaces, and riparian buffer analyses in the mid-Atlantic region. Remote Sensing of Environment 88 (1-2):195-208. http:// dx.doi.org/ 10.1016/j.rse.2003.07.010

Gorsevski, P. V., J . Boll, E. Gomezdelcampo, and E. S. Brooks. 2008. Dynamic riparian buffer widths from potential non-point source pollution areas in forested watersheds. Forest Ecology and Management 256 (4):664-673. http:// dx.doi.org/ 10.1016/j.foreco.2008.05.019

Governo, R., B. G. Lockaby, B. Rummer, and C. Colson. 2004. Silvicultural management within streamside management zones of intermittent streams: Effects on decomposition, productivity, nutrient cycling, and channel vegetation. Southern J ournal of Applied Forestry 28 (4):211-224. 
Graff, C. D., A. M. Sadeghi, R. R. Lowrance, and R. G. Williams. 2005. Quantifying the sensitivity of the riparian ecosystem management model (REMM) to changes in climate and buffer characteristics common to conservation practices. Transactions of the American Society of Agricultural Engineers 48 (4):13771387.

Greene, B. T., W. H. Lowe, and G. E. Likens. 2008. Forest succession and prey availability influence the strength and scale of terrestrial-aquatic linkages in a headwater salamander system. Freshwater Biology 53 (11):2234-2243.

Hein, C. D., S. B. Castleberry, and K. V. Miller. 2009. Site-occupancy of bats in relation to forested corridors. Forest Ecology and Management 257 (4):1200-1207. http:// www.sciencedirect.com/ science/ article/ B6T6X-4VDSCYD1/ 2/ 6a93562de1cd02c082edb3dd8ccf977f

Hession, W. C., J . E. Pizzuto, T. E. J ohnson, and R. J . Horwitz. 2003. Influence of bank vegetation on channel morphology in rural and urban watersheds. Geology 31(2):147-150.

J ohnson, B. R., J . B. Wallace, A. D. Rosemond, and W. F. Cross. 2006. Larval salamander growth responds to enrichment of a nutrient poor headwater stream. Hydrobiologia 573 (1):227-232. http:// dx.doi.org/ 10.1007/ s10750-006-0272-3

Kellogg, D. Q., A. J . Gold, P. M. Groffman, K. Addy, M. H. Stolt, and G. Blazejewski. 2005. In situ ground water denitrification in stratified, permeable soils underlying riparian wetlands. J ournal of Environmental Quality 34 (2):524-533.

Kenwick, R. A., M. R. Shammin, and W. C. Sullivan. 2009. Preferences for riparian buffers. Landscape and Urban Planning 91 (2):88-96. http:// dx.doi.org/ 10.1016/j.landurbplan.2008.12.005

Kilgo, J . C., R. A. Sargent, B. R. Chapman, and K. V. Miller. 1998. Effect of stand width and adjacent habitat on breeding bird communities in bottomland hardwoods. J ournal of Wildlife Management 62 (1):72-83.

Kissling, M. L., and E. O. Garton. 2008. Forested buffer strips and breeding bird communities in southeast Alaska. J ournal of Wildlife Management 72 (3):674681.

Kluber, M. R., D. H. Olson, and K. J . Puettmann. 2008. Amphibian distributions in riparian and upslope areas and their habitat associations on managed forest landscapes in the Oregon Coast Range. Forest Ecology and Management 256 (4):529-535. http:// dx.doi.org/ 10.1016/j.foreco.2008.04.043

Lee, P., C. Smyth, and S. Boutin. 2004. Quantitative review of riparian buffer width guidelines from Canada and the United States. J ournal of Environmental Management 70 (2):165-180.

http:// www.sciencedirect.com/science?_ob=MImg\&_imagekey=B6WJ 74BK2DJX-1-

N\&_cdi $=6871 \&$ _ user $=930810 \&$ _orig $=$ search\&_coverDate $=02 \% 2 \mathrm{~F} 29 \% 2 \mathrm{~F} 2004$ \&_ sk=999299997\&view=c\&wchp=dGLbVtbzS̄kWz\&md5=032809d30e7972d7e730c56cf284ec87\&ie=/ sdarticle.pdf 
Liechty, H. O., and J. M. Guldin. 2009. Structure and composition of streamside management zones following reproduction cutting in shortleaf pine stands. Forest Ecology and Management 258 (7):1407-1413. http:// dx.doi.org/ 10.1016/j.foreco.2009.06.044

Line, D. E. 2003. Changes in a stream's physical and biological conditions following livestock exclusion. Transactions of the American Society of Agricultural Engineers 46 (2):287-293.

Liquori, M. K. 2006. Post-harvest riparian buffer response: Implications for wood recruitment modeling and buffer design. J ournal of the American Water Resources Association 42 (1):177-189.

Lowrance, R., and J . M. Sheridan. 2005. Surface runoff water quality in a managed three zone riparian buffer. J ournal of Environmental Quality 34 (5):1851-1859. http:// dx.doi.org/ 10.2134/ jeq2004.0291

MacDonald, L. H., and D. Coe. 2007. Influence of headwater streams on downstream reaches in forested areas. Forest Science 53 (2):148-168.

Magner, J . A., B. Vondracek, and K. N. Brooks. 2008. Grazed riparian management and stream channel response in southeastern Minnesota (USA) streams.

Environmental Management 42 (3):377-390.

http:// dx.doi.org/ 10.1007/s00267-008-9132-4

Martin, D. J ., and R. A. Grotefendt. 2007. Stand mortality in buffer strips and the supply of woody debris to streams in Southeast Alaska. Canadian J ournal of Forest Research 37 (1):36-49. http:// dx.doi.org/ 10.1139/X06-209

Martinet, M. C., E. R. Vivoni, J . R. Cleverly, J . R. Thibault, J . F. Schuetz, and C. N. Dahm. 2009. On groundwater fluctuations, evapotranspiration, and understory removal in riparian corridors. Water Resources Research 45 (5).

http://dx.doi.org/10.1029/2008WR007152

Mason, J., C. Moorman, G. Hess, and K. Sinclair. 2007. Designing suburban greenways to provide habitat for forest-breeding birds. Landscape and Urban Planning 80 (1-2):153-164.

http://www.sciencedirect.com/science?_ob=ArticleURL\&_udi=B6V914KPN9NS-

$1 \&$ user $=930810 \&$ _doc $=1 \&$ fmt $=\&$ _ orig $=$ search\&_sort=d\&_docanchor $=\& v i e$

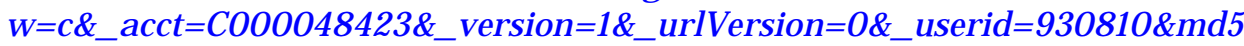
$=$ caee519a9c77a37ac921f8869c146958

McDonough, C., and P. W. C. Paton. 2007. Salamander dispersal across a forested landscape fragmented by a golf course. J ournal of Wildlife Management 71(4):1163-1169.

Meiklejohn, B. A., and J . W. Hughes. 1999. Bird communities in riparian buffer strips of industrial forests. American Midland Naturalist 141 (1):172-184.

Moseley, K., W. Ford, and J . Edwards. 2009. Local and landscape scale factors influencing edge effects on woodland salamanders. Environmental Monitoring and Assessment 151 (1):425-435. http:// dx.doi.org/ 10.1007/ s10661-008-0286-6 
Muenz, T. K., S. W. Golladay, G. Vellidis, and L. L. Smith. 2006. Stream buffer effectiveness in an agriculturally influenced area, southwestern Georgia: Responses of water quality, macroinvertebrates, and amphibians. J ournal of Environmental Quality 35 (5): 1924-1938. http: / / dx.doi.org/ 10.2134/ jeq2005.0456

Olson, D. H., P. D. Anderson, C. A. Frissell, H. H. Welsh Jr, and D. F. Bradford. 2007. Biodiversity management approaches for stream-riparian areas: Perspectives for Pacific Northwest headwater forests, microclimates, and amphibians. Forest Ecology and Management 246 (1SPEC. ISS.):81-107. http://dx.doi.org/ 10.1016/j.foreco.2007.03.053

Peak, R. G., and F. R. Thompson. 2006. Factors affecting avian species richness and density in riparian areas. J ournal of Wildlife Management 70 (1):173-179.

Pennington, D. N., J . Hansel, and R. B. Blair. 2008. The conservation value of urban riparian areas for landbirds during spring migration: Land cover, scale, and vegetation effects. Biological Conservation 141(5):1235-1248. http:/ / www.sciencedirect.com/science?_ob=MImg\&_imagekey=B6V5X4S6GRTS-1-

9\&_cdi $=5798 \&$ _ user $=930810 \&$ orig $=$ search\&_coverDate $=05 \% 2 \mathrm{~F} 31 \% 2 \mathrm{~F} 2008 \&$ sk $=998589994 \& v i e w=c \& w c h p=d G L b V l z-$ zSkWz\&md5=3ead10f79f8cd874709c7af5dd43e601\&ie=/ sdarticle.pdf

Perkins, D. W., and M. L. Hunter. 2006. Effects of riparian timber management on amphibians in Maine. J ournal of Wildlife Management 70 (3):657-670.

2006. Use of amphibians to define riparian zones of headwater streams. Canadian J ournal of Forest Research-Revue Canadienne De Recherche Forestiere 36 (9):2124-2130.

Peterman, W. E., and R. D. Semlitsch. 2009. Efficacy of riparian buffers in mitigating local population declines and the effects of even-aged timber harvest on larval salamanders. Forest Ecology and Management 257 (1):8-14. http:// dx.doi.org/10.1016/j.foreco.2008.08.011

Porter, E. E., J . Bulluck, and R. B. Blair. 2005. Multiple spatial-scale assessment of the conservation value of golf courses for breeding birds southwestern Ohio. Wildlife Society Bulletin 33 (2):494-506.

Prisley, S. P., D. R. Daversa, and M. J . Mortimer. 2006. Estimation of forest area affected by local ordinances: A Virginia case study. Southern J ournal of Applied Forestry 30 (4):188-195.

Qiu, Z., T. Prato, and G. Boehm. 2006. Economic valuation of riparian buffer and open space in a suburban watershed. J ournal of the American Water Resources Association 42 (6): 1583-1596. http:// dx.doi.org/ 10.1111/j.17521688.2006.tb06022.x

Rich, A. C., D. S. Dobkin, and L. J . Niles. 1994. Defining forest fragmentation by corridor width: The influence of narrow forest-dividing corridors on forest-nesting birds in southern NewJ ersey. Conservation Biology 8 (4):1109-1121. http:// www.jstor.org/ stable/ 2386581 
Richardson, J . S., and R. J . Danehy. 2007. A synthesis of the ecology of headwater streams and their riparian zones in temperate forests. Forest Science 53 (2):131147.

Ringold, P. L., J . Van Sickle, M. Bollman, J . Welty, and J . Barker. 2009. Riparian forest indicators of potential future stream condition. Ecological Indicators 9 (3):462475. http:// dx.doi.org/ 10.1016/j.ecolind.2008.06.009

Rittenhouse, T. A. G., and R. D. Semlitsch. 2007. Distribution of amphibians in terrestrial habitat surrounding wetlands. Wetlands 27 (1):153-161.

Rivenbark, B. L., and C. R. J ackson. 2004. Concentrated flow breakthroughs moving through silvicultural streamside management zones: Southeastern Piedmont, USA. J ournal of the American Water Resources Association 40 (4):1043-1052.

Rodewald, A. D., and M. H. Bakermans. 2006. What is the appropriate paradigm for riparian forest conservation? Biological Conservation 128 (2):193-200. http://www.sciencedirect.com/science?_ob=MImg\&_imagekey=B6V5X4HNSB83-1$5 \&$ _cdi $=5798 \&$ _ user $=930810 \&$ \& orig $=$ search\&_coverDate $=03 \% 2 \mathrm{~F} 31 \% 2 \mathrm{~F} 2006 \&$ sk $=998719997 \&$ kview $=$ c\&wchp=dGLzVlzzSkWz\&md5=91f77aa2e292ee51c544d4c73f9a8181\&ie=/ sdarticle.pdf

Roy, A. H., M. C. Freeman, B. J . Freeman, S. J . Wenger, J . L. Meyer, and W. E. Ensign. 2006. Importance of riparian forests in urban catchments contingent on sediment and hydrologic regimes. Environmental Management 37 (4):523-539. http:/ / dx.doi.org/ 10.1007/ s00267-005-0029-1

Sahu, M., and R. R. Gu. 2009. Modeling the effects of riparian buffer zone and contour strips on stream water quality. Ecological Engineering 35 (8):1167-1177. http:// dx.doi.org/ 10.1016/j.ecoleng.2009.03.015

Sallabanks, R., J . R. Walters, and J . A. Collazo. 2000. Breeding bird abundance in bottomland hardwood forests: habitat, edge, and patch size effects. The Condor 102 (4): 748-758. http:/ / dx.doi.org/ 10.1650/00105422(2000)102[0748: BBAIBH]2.0.CO; 2

Schilling, K. E., Z. Li, and Y.-K. Zhang. 2006. Groundwater-surface water interaction in the riparian zone of an incised channel, Walnut Creek, Iowa. J ournal of Hydrology 327 (1-2):140-150. http:// dx.doi.org/ 10.1016/j.jhydrol.2005.11.014

Shields, F. D., C. M. Cooper J r, S. S. Knight, and M. T. Moore. 2003. Stream corridor restoration research: A long and winding road. Ecological Engineering 20 (5):441-454. http:// dx.doi.org/ 10.1016/j.ecoleng.2003.08.005

Shirley, S. M. 2006. Movement of forest birds across river and clearcut edges of varying riparian buffer strip widths. Forest Ecology and Management 223 (1-3):190-199. http:// www.sciencedirect.com/science?_ob=ArticleURL\&_udi=B6T6X4HWX8WP-

$3 \&$ user $=930810 \&$ \&doc $=1 \&$ fmt $=\& \_$orig $=$search\&_sort=d\&_docanchor $=\&$ vie

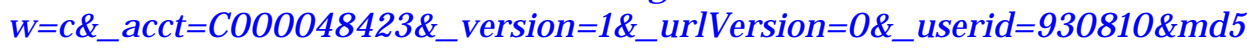
$=8 \mathrm{fd} 3 \bar{b} f 1 \mathrm{cee} 24 \mathrm{f} 32 \mathrm{c} 34 \mathrm{fd} 4040138 \mathrm{ad} 435$ 
Skidds, D. E., F. C. Golet, P. W. C. Paton, and J . C. Mitchell. 2007. Habitat correlates of reproductive effort in wood frogs and spotted salamanders in an urbanizing watershed. J ournal of Herpetology 41 (3):439-450.

Sovell, L. A., B. Vondracek, J . A. Frost, and K. G. Mumford. 2000. Impacts of rotational grazing and riparian buffers on physicochemical and biological characteristics of Southeastern Minnesota, USA, streams. Environmental Management 26 (6):629-641. http:/ / dx.doi.org/ 10.1007/ s002670010121

Spruill, T. B. 2004. Effectiveness of riparian buffers in controlling ground-water discharge of nitrate to streams in selected hydrogeologic settings of the North Carolina Coastal Plain. Water Science and Technology 49 (3):63-70.

Vellidis, G., and R. Lowrance. 2004. Riparian forest buffers. Resource: Engineering and Technology for Sustainable World 11 (10):7-8.

Vellidis, G., R. Lowrance, P. Gay, and R. D. Wauchope. 2002. Herbicide transport in a restored riparian forest buffer system. Transactions of the American Society of Agricultural Engineers 45 (1):89-97.

Walter, M. T., J . A. Archibald, B. Buchanan, H. Dahlke, Z. M. Easton, R. D. Marjerison, A. N. Sharma, and S. B. Shaw. 2009. New paradigm for sizing riparian buffers to reduce risks of polluted storm water: Practical synthesis. J ournal of Irrigation and Drainage Engineering 135 (2):200-209. http:// dx.doi.org/ 10.1061/(ASCE)0733-9437(2009)135:2(200)

Warren, D. R., and C. E. Kraft. 2008. Dynamics of large wood in an eastern U.S. mountain stream. Forest Ecology and Management 256 (4):808-814. http:// dx.doi.org/ 10.1016/j.foreco.2008.05.038

Washington State Department of Transportation (WSDOT). 2008. Wetland and Buffer Impact Assessment Guidance.: Washington State Department of Transportation http:// www.wsdot.wa.gov/ NR/ rdonlyres/ D0FE60A8-A193-4615-A68427E66CFBFB61/ 0/WetMitBuffImpAssess.pdf.

Whitaker, D. M., and W. A. Montevecchi. 1999. Breeding bird assemblages inhabiting riparian buffer strips in Newfoundland, Canada. J ournal of Wildlife Management 63 (1):167-179.

Wigington, P. J ., J r., T. J . Moser, and D. R. Lindeman. 2005. Stream network expansion: A riparian water quality factor. Hydrological Processes 19 (8):1715-1721. http:// dx.doi.org/ 10.1002/ hyp.5866

Wigington, P. J ., J r., T. J . Moser, and D. R. Lindeman. 2005. Stream network expansion: A riparian water quality factor. Hydrological Processes 19 (8):1715-1721. http:// dx.doi.org/ 10.1002/ hyp.5866

Wilkerson, E., J. M. Hagan, D. Siegel, and A. A. Whitman. 2006. The effectiveness of different buffer widths for protecting headwater stream temperature in Maine. Forest Science 52 (3):221-231. 
Williams, T. M., D. J . Lipscomb, W. R. English, and C. Nickel. 2003. Mapping variableWidth streamside management zones for water quality protection. Biomass and Bioenergy 24 (4-5):329-336. http:// dx.doi.org/ 10.1016/ S09619534(02)00168-X

Wipfli, M. S. 2005. Trophic linkages between headwater forests and downstream fish habitats: Implications for forest and fish management. Landscape and Urban Planning 72 (1-3):205-213.

http:// dx.doi.org/ 10.1016/j.landurbplan.2004.09.025

Wipfli, M. S., J. S. Richardson, and R. J . Naiman. 2007. Ecological linkages between headwaters and downstream ecosystems: Transport of organic matter, invertebrates, and wood down headwater channels. J ournal of the American Water Resources Association 43 (1):72-85. http:// dx.doi.org/ 10.1111/j.17521688.2007.00007.x

Woodcock, T. S., and A. D. Huryn. 2004. Effects of roadway crossings on leaf litter processing and invertebrate assemblages in small streams. Environmental Monitoring and Assessment 93 (1-3):229-250. http:// dx.doi.org/ 10.1023/ B:EMAS.0000016802.98218.4e

Yahner, R. H. 1988. Changes in wildlife communities near edges. Conservation Biology 2 (4):333-339. http:// www.jstor.org/ stable/ 2386292

Yamada, T., S. D. Logsdon, M. D. Tomer, and M. R. Burkart. 2007. Groundwater nitrate following installation of a vegetated riparian buffer. Science of the Total Environment 385 (1-3):297-309. http:// dx.doi.org/ 10.1016/j.scitotenv.2007.06.035

Zaimes, G. N., R. C. Schultz, and T. M. Isenhart. 2006. Riparian land uses and precipitation influences on stream bank erosion in central Iowa. J ournal of the American Water Resources Association 42 (1):83-97.

_. 2008. Streambank soil and phosphorus losses under different riparian land-uses in Iowa. J ournal of the American Water Resources Association 44 (4):935-947. http:/ / dx.doi.org/ 10.1111/j.1752-1688.2008.00210.x

Ziegler, A. D., J . Negishi, R. C. Sidle, P. Preechapanya, R. A. Sutherland, T. W. Giambelluca, and S. J aiaree. 2006. Reduction of stream sediment concentration by a riparian buffer: Filtering of road runoff in disturbed headwater basins of Montane Mainland Southeast Asia. J ournal of Environmental Quality 35 (1):151162. http:// dx.doi.org/ 10.2134/jeq2005.0103 


\section{Appendix C: Cumulative Impacts}

Brown, M. T., and M. B. Vivas. 2005. Landscape development intensity index. Environmental Monitoring and Assessment 101(1-3):289-309. http:// www.springerlink.com/ content/j133h5g4748578v7/ fulltext.pdf

Cote, D., D. G. Kehler, C. Bourne, and Y. F. Wiersma. 2009. A new measure of longitudinal connectivity for stream networks. Landscape Ecology 24 (1):101-113. http: // www.springerlink.com/ content/1511w82281n65515/ fulltext.pdf

Crain, C. M., B. S. Halpern, M. W. Beck, and C. V. Kappel. 2009. Understanding and managing human threats to the coastal marine environment. Year in Ecology and Conservation Biology 2009 1162:39-62.

Forys, E. A., C. R. Allen, and D. P. Wojcik. 2002. Influence of the proximity and amount of human development and roads on the occurrence of the red imported fire ant in the lower Florida Keys. Biological Conservation 108 (1):27-33.

http:// www.sciencedirect.com/ science?_ob=MImg\&_imagekey=B6V5X45BCPDD-3-

$4 \& \_$cdi $=5798 \&$ _ user $=930810 \&$ \& orig $=$ search\&_coverDate $=11 \% 2 F 30 \% 2 F 2002 \&$ sk $=998919998 \& v i e w=c \& w c h p=d G L z V t b-$ zSkzV\&md5=17d341129e2fbb49ca837c71f5c62d6d\&ie=/ sdarticle.pdf

Gergel, S. E. 2002. Assessing cumulative impacts of levees and dams on floodplain ponds: A neutral-terrain model approach. Ecological Applications 12 (6):1740-1754.

Gilman, E. L. 1998. Nationwide permit program: Unknown adverse impacts on the commonwealth of the Northern Mariana Islands' wetlands. Coastal Management 26 (4):253-277.

http:// www.informaworld.com/ smpp/ content $\sim \mathrm{db}=\mathrm{all}$ ?content=10.1080/ 0892 0759809362357

Girvetz, E. H., J . H. Thorne, A. M. Berry, and J . A. G. J aeger. 2008. Integration of landscape fragmentation analysis into regional planning: A statewide multi-scale case study from California, USA. Landscape and Urban Planning 86 (3-4):205218. http:// www.sciencedirect.com/science?_ob=ArticleURL\&_udi=B6V914SDNK43-

$1 \&_{-}$user $=930810 \&$ rdoc $=1 \&_{-}$fmt $=\& \_$orig $=$search\&_sort=d\&_docanchor $=\& v i e$ $\mathrm{w}=\mathrm{c} \&$ a acct $=$ C000048423\&_version $=1 \&$ _ urlVersion $=0 \&$ _ userid $=930810 \& \mathrm{md} 5$ $=78 \mathrm{c} 7 \mathrm{~d} 7 \mathrm{~d} 80 \mathrm{ff} 44 \mathrm{cb} 1 \mathrm{da} 47 \mathrm{df} 7 \mathrm{bb} 0131 \mathrm{~b} 36$

Grimes, G., L. Pesesky, J . S. Lane, and C. Szwarckop. 2004. Eight-step process for assessing indirect and cumulative impacts of transportation projects. Energy and Environmental Concerns 2004 (1880):144-150.

Gwin, S. E., M. E. Kentula, and P. W. Shaffer. 1999. Evaluating the effects of wetland regulation through hydrogeomorphic classification and landscape profiles. Wetlands 19 (3):477-489.

Hirsch, A. 1988. Regulatory context for cumulative impact research. Environmental Management 12 (5):715-723. http:// dx.doi.org/ 10.1007/ BF01867548 
Nellemann, C., I. Vistnes, P. J ordhoy, O. Strand, and A. Newton. 2003. Progressive impact of piecemeal infrastructure development on wild reindeer. Biological Conservation 113 (2):307-317.

http: // www.sciencedirect.com/science?_ob=MImg\&_imagekey=B6V5X4899XGK-3-

H\&_cdi $=5798 \&$ _ user $=930810 \&$ _orig $=$ search\&_coverDate $=10 \% 2 \mathrm{~F} 31 \% 2 \mathrm{~F} 2003$ \& sk=998869997\&view=c\&wchp=dGLbVzzzSkWA\&md5=372e87cbd437e28e5aa162680016152f\&ie=/ sdarticle.pdf

NRC (National Research Council). 2001. Compensating for Wetland Losses Under the Clean Water Act. Washington, DC: National Academy Press.

http:// www.nap.edu/catalog.php?record_id=10134

Peterson, C. H., and M. J . Bishop. 2005. Assessing the environmental impacts of beach nourishment. Bioscience 55 (10):887-896.

Pinay, G., J . C. Clement, and R. J . Naiman. 2002. Basic principles and ecological consequences of changing water regimes on nitrogen cycling in fluvial systems. Environmental Management 30 (4):481-491. http:// www.springerlink.com/ content/ ka7fnp1rt7jqygfy/ fulltext.pdf

Pinter, N., B. S. Ickes, J . H. Wlosinski, and R. R. van der Ploeg. 2006. Trends in flood stages: Contrasting results from the Mississippi and Rhine River systems. J ournal of Hydrology 331 (3-4):554-566. http:// www.sciencedirect.com/science?_ob=MImg\&_imagekey=B6V6C$4 \mathrm{KKNJ} 8 \mathrm{~F}-1-$

$3 \&$ _cdi $=5811 \&$ _ user $=930810 \&$ orig $=$ search\&_coverDate $=12 \% 2 F 15 \% 2 F 2006 \&$ sk $=996689996 \& v i e w=c \& w c h p=d G L b V z W-$

zSkzV\&md5=7b22cee9b1f5f3748c58c80d0abfa3a8\&ie=/ sdarticle.pdf

Portman, M. E., D. J in, and E. Thunberg. 2009. Waterfront land use change and marine resource conditions: The case of New Bedford and Fairhaven, Massachusetts. Ecological Economics 68 (8-9):2354-2362.

http:// www.sciencedirect.com/science?_ob=ArticleURL\&_udi=B6VDY4W4VT0X-

$1 \&$ _ user $=930810 \& \_$rdoc $=1 \& \_$fmt $=\& \_$orig $=$search\&_sort=d\&_docanchor $=$\&vie $\mathrm{w}=\mathrm{c} \&$ acct $=\mathrm{C} 000048423 \&$ version $=1 \varepsilon_{-}$urlVersion $=0 \&$ \& userid $=930810 \& \mathrm{md} 5$ $=\mathrm{d} 7509 \mathrm{a} 783 \mathrm{c} 9 \mathrm{bab3bc1a14a98a4460 \textrm {d } 9 6}$

Radomski, P., and T. J . Goeman. 2001. Consequences of human lakeshore development on emergent and floating-leaf vegetation abundance. North American J ournal of Fisheries Management 21(1):46-61.

Sanger, D. M., A. F. Holland, and C. Gainey. 2004. Cumulative impacts of dock shading on Spartina alterniflora in South Carolina estuaries. Environmental Management 33 (5):741-748.

http:/ / www.springerlink.com/ content/ 8rg58ym3fermyq6n/ fulltext.pdf

Sanger, D. M., A. F. Holland, and D. L. Hernandez. 2004. Evaluation of the impacts of dock structures and land use on tidal creek ecosystems in South Carolina estuarine environments. Environmental Management 33 (3):385-400. http:/ / www.springerlink.com/ content/ qu714c2tm7cxt79r/ fulltext.pdf 
Scott, M. C., G. S. Helfman, M. E. McTammany, E. F. Benfield, and P. V. Bolstad. 2002. Multiscale influences on physical and chemical stream conditions across blue ridge landscapes. J ournal of the American Water Resources Association 38 (5):1379-1392.

Stein, E. D., and R. E. Ambrose. 1998. Cumulative impacts of Section 404 Clean Water Act permitting on the riparian habitat of the Santa Margarita, California watershed. Wetlands 18 (3):393-408.

Stein, E. D., and R. F. Ambrose. 2001. Landscape-scale analysis and management of cumulative impacts to riparian ecosystems: Past, present, and future. J ournal of the American Water Resources Association 37 (6):1597-1614.

Stein, E. D., F. Tabatabai, and R. F. Ambrose. 2000. Wetland mitigation banking: A framework for crediting and debiting. Environmental Management 26 (3):233250. http:// www.springerlink.com/ content/jj410vauk74un7pm/ fulltext.pdf

Swenson, D. P., and R. F. Ambrose. 2007. A spatial analysis of cumulative habitat loss in Southern California under the Clean Water Act Section 404 program. Landscape and Urban Planning 82 (1-2):41-55.

http:// www.sciencedirect.com/science?_ob=ArticleURL\&_udi=B6V91-

4N7YFK3-

$2 \& \_$user $=930810 \& \_r d o c=1 \& \_\mathrm{fmt}=\& \_$orig $=$search\&_sort $=\mathrm{d} \& \_$docanchor $=\& v i e$ $\mathrm{w}=\mathrm{c} \&$ acct $=\mathrm{C} 000048423 \&$ version $=1$ \&_ urlVersion $^{-} 0$ \&_ userid $=930810 \& \mathrm{md} 5$ $=\mathrm{a} 9 \mathrm{adb} 4 \mathrm{~d} 99 \mathrm{~b} 5 f 5 f 69 \mathrm{ebe} 19 \mathrm{f} 4160 \mathrm{fbb} 49 \mathrm{c}$

Syphard, A. D., and M. W. Garcia. 2001. Human- and beaver-induced wetland changes in the Chickahominy River watershed from 1953 to 1994. Wetlands 21 (3):342-353.

Tiner, R. W. 2005. Assessing cumulative loss of wetland functions in the Nanticoke River watershed using enhanced National Wetlands Inventory data. Wetlands 25 (2):405-419.

Wheeler, A. P., P. L. Angermeier, and A. E. Rosenberger. 2005. Impacts of new highways and subsequent landscape urbanization on stream habitat and biota. Reviews in Fisheries Science 13 (3):141-164.

http:/ / www.informaworld.com/ smpp/ content $\sim \mathrm{db}=\mathrm{all}$ ?content=10.1080/ 10641 260590964449

Wissmar, R. C. 2004. Riparian corridors of Eastern Oregon and Washington: Functions and sustainability along lowland-arid to mountain gradients. Aquatic Sciences 66 (4):373-387.

http:// www.springerlink.com/ content/5x3u10h9ayvc0c8u/fulltext.pdf

Zedler, J . B., and S. Kercher. 2004. Causes and consequences of invasive plants in wetlands: Opportunities, opportunists, and outcomes. Critical Reviews in Plant Sciences 23 (5):431-452.

http:// www.informaworld.com/smpp/ content $\sim d b=a l l$ ?content $=10.1080 / 07352$ 680490514673 


\section{Appendix D: Development and Urban Impacts}

Ackerman, D., and E. D. Stein. 2008. Estimating the variability and confidence of land use and imperviousness relationships at a regional scale. J ournal of the American Water Resources Association 44 (4):996-1008. http:// dx.doi.org/ 10.1111/j.1752-1688.2008.00215.x

Allen, P. M., J . G. Arnold, and W. Shipwith. 2008. Prediction of channel degradation rates in urbanizing watersheds. Hydrological Sciences J ournal 53 (5):1013-1029. http:/ / dx.doi.org/ 10.1623/ hysj.53.5.1013

Allmendinger, N. E., J. E. Pizzuto, G. E. Moglen, and M. Lewicki. 2007. A sediment budget for an urbanizing watershed, 1951-1996, Montgomery County, Maryland, U.S.A. J ournal of the American Water Resources Association 43 (6): 1483-1498. http:// dx.doi.org/ 10.1111/j.1752-1688.2007.00122.x

Benotti, M. J ., and B. J . Brownawell. 2007. Distributions of pharmaceuticals in an urban estuary during both dry- and wet-weather conditions. Environmental Science and Technology 41(16):5795-5802. http:// dx.doi.org/ 10.1021/ es0629965

Bledsoe, B. P., and C. C. Watson. 2001. Effects of urbanization on channel instability. J ournal of the American Water Resources Association 37 (2):255-270.

Booth, D. B., D. Hartley, and R. J ackson. 2002. Forest cover, impervious-surface area, and the mitigation of stormwater impacts. J ournal of the American Water Resources Association 38 (3):835-845.

Brett, M. T., G. B. Arhonditsis, S. E. Mueller, D. M. Hartley, J . D. Frodge, and D. E. Funke. 2005. Non-point-source impacts on stream nutrient concentrations along a forest to urban gradient. Environmental Management 35 (3):330-342. http:// dx.doi.org/ 10.1007/ s00267-003-0311-z

Budd, R., S. Bondarenko, D. Haver, J . Kabashima, and J . Gan. 2007. Occurrence and bioavailability of pyrethroids in a mixed land use watershed. J ournal of Environmental Quality 36 (4):1006-1012. http:// dx.doi.org/ 10.2134/ jeq2006.0249

Burdick, D., and R. Konisky. 2003. Determinants of expansion for Phragmites australis, common reed, in natural and impacted coastal marshes. Estuaries and Coasts 26 (2):407-416. http:// dx.doi.org/ 10.1007/ BF02823717

Burns, D., T. Vitvar, J . McDonnell, J . Hassett, J . Duncan, and C. Kendall. 2005. Effects of suburban development on runoff generation in the Croton River basin, New York, USA. J ournal of Hydrology 311 (1-4):266-281.

http:// dx.doi.org/ 10.1016/j.jhydrol.2005.01.022

Canuel, E. A., E. J . Lerberg, R. M. Dickhut, S. A. Kuehl, T. S. Bianchi, and S. G. Wakeham. 2009. Changes in sediment and organic carbon accumulation in a highlydisturbed ecosystem: The Sacramento-San J oaquin River Delta (California, USA). Marine Pollution Bulletin 59 (4-7):154-163.

http:// dx.doi.org/ 10.1016/j.marpolbul.2009.03.025 
Casey, R. E., J . A. Simon, S. Atueyi, J . W. Snodgrass, N. Karouna-Renier, and D. W. Sparling. 2007. Temporal trends of trace metals in sediment and invertebrates from stormwater management ponds. Water, Air, and Soil Pollution 178 (1-4):69-77. http:// dx.doi.org/ 10.1007/ s11270-006-9132-z

Chalmers, A. T., P. C. Van Metre, and E. Callender. 2007. The chemical response of particle-associated contaminants in aquatic sediments to urbanization in New England, U.S.A. J ournal of Contaminant Hydrology 91 (1-2):4-25. http:// dx.doi.org/ 10.1016/j.jconhyd.2006.08.007

Chen, J ., A. A. Hill, and L. D. Urbano. 2009. A GIS-based model for urban flood inundation. J ournal of Hydrology 373 (1-2):184-192. http:// dx.doi.org/ 10.1016/j.jhydrol.2009.04.021

Cho, J ., V. A. Barone, and S. Mostaghimi. 2009. Simulation of land use impacts on groundwater levels and streamflow in a Virginia watershed. Agricultural Water Management 96 (1):1-11. http:// dx.doi.org/ 10.1016/j.agwat.2008.07.005

Cho, S.-H., and D. H. Newman. 2005. Spatial analysis of rural land development. Forest Policy and Economics 7 (5):732-744. http:// dx.doi.org/ 10.1016/j.forpol.2005.03.008

Cianfrani, C. M., W. C. Hession, and D. M. Rizzo. 2006. Watershed imperviousness impacts on stream channel condition in southeastern Pennsylvania. J ournal of the American Water Resources Association 42 (4):941-956. http:// dx.doi.org/ 10.1111/j.1752-1688.2006.tb04506.x

Clinton, B. D., and J . M. Vose. 2006. Variation in stream water quality in an urban headwater stream in the southern appalachians. Water, Air, and Soil Pollution 169 (1-4):331-353. http:// dx.doi.org/ 10.1007/ s11270-006-2812-x

Coats, R., M. Larsen, A. Heyvaert, J . Thomas, M. Luck, and J . Reuter. 2008. Nutrient and sediment production, watershed characteristics, and land use in the Tahoe Basin, California-Nevada. J ournal of the American Water Resources Association 44 (3):754-770. http:/ / dx.doi.org/ 10.1111/j.1752-1688.2008.00203.x

Conway, T. M., and R. G. Lathrop. 2005. Alternative land use regulations and environmental impacts: Assessing future land use in an urbanizing watershed. Landscape and Urban Planning 71 (1):1-15. http:// dx.doi.org/ 10.1016/j.landurbplan.2003.08.005

Coppes, B. A. 2002. The challenges of stormwater management. Water Engineering and Management 149 (11):18-23.

Dougherty, M., R. L. Dymond, T. J . Grizzard J r, A. N. Godrej, C. E. Zipper, and J. Randolph. 2006. Quantifying long-term NPS pollutant flux in an urbanizing watershed. J ournal of Environmental Engineering 132 (4):547-554. http:// dx.doi.org/10.1061/(ASCE)0733-9372(2006)132:4(547)

Ehrenfeld, J . G. 2000. Evaluating wetlands within an urban context. Urban Ecosystems 4 (1):69-85. http:// dx.doi.org/ 10.1023/ A: 1009543920370 
Fanning, D. S., C. Coppock, Z. W. Orndorff, W. L. Daniels, and M. C. Rabenhorst. 2004. Upland active acid sulfate soils from construction of new Stafford County, Virginia, USA, Airport. Australian J ournal of Soil Research 42 (5-6):527-536.

Faulkner, S. 2004. Urbanization impacts on the structure and function of forested wetlands. Urban Ecosystems 7 (2):89-106. http:// dx.doi.org/ 10.1023/ B:UECO.0000036269.56249.66

Galatowitsch, S. M., D. C. Whited, R. Lehtinen, J . Husveth, and K. Schik. 2000. The Vegetation of Wet Meadows in Relation to Their Land-use. Environmental Monitoring and Assessment 60 (2):121-144. http:/ / dx.doi.org/ 10.1023/ A: 1006159028274

Galster, J . C., F. J . Pazzaglia, and D. Germanoski. 2008. Measuring the impact of urbanization on channel widths using historic aerial photographs and modern surveys. J ournal of the American Water Resources Association 44 (4):948-960. http:/ / dx.doi.org/ 10.1111/j.1752-1688.2008.00193.x

Gardner, C. B., and A. E. Carey. 2004. Trace metal and major ion inputs into the Olentangy River from an urban storm sewer. Environmental Science and Technology 38 (20):5319-5326. http:// dx.doi.org/ 10.1021/ es0497835

Gilroy, K. L., and R. H. McCuen. 2009. Spatio-temporal effects of low impact development practices. J ournal of Hydrology 367 (3-4):228-236. http:/ / dx.doi.org/ 10.1016/j.jhydrol.2009.01.008

Goldman Martone, R., and K. Wasson. 2008. Impacts and interactions of multiple human perturbations in a California salt marsh. Oecologia 158 (1):151-163. http:/ / dx.doi.org/ 10.1007/ s00442-008-1129-4

Grable, J . L., and C. P. Harden. 2006. Geomorphic response of an Appalachian Valley and Ridge stream to urbanization. Earth Surface Processes and Landforms 31 (13):1707-1720. http:// dx.doi.org/ 10.1002/ esp.1433

Graf, W. L. 2000. Locational probability for a dammed, urbanizing stream: Salt River, Arizona, USA. Environmental Management 25 (3):321-335. http:// dx.doi.org/ 10.1007/ s002679910025

Gray, L. 2004. Changes in water quality and macroinvertebrate communities resulting from urban stormflows in the Provo River, Utah, U.S.A. Hydrobiologia 518 (1-3):33-46. http:// dx.doi.org/ 10.1023/ B:HYDR.0000025055.15164.40

Gresens, S. E., K. T. Belt, J . A. Tang, D. C. Gwinn, and P. A. Banks. 2007. Temporal and spatial responses of Chironomidae (Diptera) and other benthic invertebrates to urban stormwater runoff. Hydrobiologia 575 (1):173-190. http:// dx.doi.org/ 10.1007/ s10750-006-0366-y

Hale, R. L., and P. M. Groffman. 2006. Chloride effects on nitrogen dynamics in forested and suburban stream debris dams. J ournal of Environmental Quality 35 (6):2425-2432. http:// dx.doi.org/ 10.2134/ jeq2006.0164 
Harrell, L. J., and R. S. Ranjithan. 2003. Detention pond design and land use planning for watershed management. J ournal of Water Resources Planning and Management 129 (2):98-106. http:// dx.doi.org/ 10.1061/ (ASCE)07339496(2003)129: 2(98)

Hauer, F. R., J. A. Stanford, and M. S. Lorang. 2007. Pattern and process in Northern Rocky Mountain headwaters: Ecological linkages in the headwaters of the crown of the continent. J ournal of the American Water Resources Association 43 (1):104-117. http:// dx.doi.org/ 10.1111/j.1752-1688.2007.00009.x

Helms, B. S., J . E. Schoonover, and J. W. Feminella. 2009. Assessing influences of hydrology, physicochemistry, and habitat on stream fish assemblages across a changing landscape. J ournal of the American Water Resources Association 45 (1):157-169. http:// dx.doi.org/ 10.1111/j.1752-1688.2008.00267.x

Herb, W. R., B. J anke, O. Mohseni, and H. G. Stefan. 2008. Ground surface temperature simulation for different land covers. J ournal of Hydrology 356 (3-4):327-343. http:// dx.doi.org/ 10.1016/j.jhydrol.2008.04.020

- 2008. Thermal pollution of streams by runoff from paved surfaces. Hydrological Processes 22 (7):987-999. http:// dx.doi.org/ 10.1002/ hyp.6986

Hess, A. J ., and P. A. J ohnson. 2001. A systematic analysis of the constraints to urban stream enhancements. J ournal of the American Water Resources Association 37 (1):213-221.

Hintzen, E. P., M. J . Lydy, and J . B. Belden. 2009. Occurrence and potential toxicity of pyrethroids and other insecticides in bed sediments of urban streams in central Texas. Environmental Pollution 157 (1):110-116. http:// dx.doi.org/ 10.1016/j.envpol.2008.07.023

Horowitz, A. J ., K. A. Elrick, and J . J . Smith. 2008. Monitoring urban impacts on suspended sediment, trace element, and nutrient fluxes within the City of Atlanta, Georgia, USA: Program design, methodological considerations, and initial results. Hydrological Processes 22 (10):1473-1496.

http:/ / dx.doi.org/ 10.1002/ hyp.6699

Houser, D. L., and H. Pruess. 2009. The effects of construction on water quality: A case study of the culverting of Abram Creek. Environmental Monitoring and Assessment 155 (1-4):431-442. http:// dx.doi.org/ 10.1007/ s10661-008-0445-9

Hwang, H.-M., and G. D. Foster. 2008. Polychlorinated biphenyls in stormwater runoff entering the tidal Anacostia River, Washington, DC, through small urban catchments and combined sewer outfalls. J ournal of Environmental Science and Health - Part A Toxic/ Hazardous Substances and Environmental Engineering 43 (6):567-575. http:// dx.doi.org/ 10.1080/ 10934520801893527

J ohnston, C. A., T. Watson, and P. T. Wolter. 2007. Sixty-three years of land alteration in Erie Township. J ournal of Great Lakes Research 33 (SPEC. ISS. 3):253-268.

Kentula, M. E., S. E. Gwin, and S. M. Pierson. 2004. Tracking changes in wetlands with urbanization: Sixteen years of experience in Portland, Oregon, USA. Wetlands 24 (4): $734-743$. 
Kimbrough, K. L., and R. M. Dickhut. 2006. Assessment of polycyclic aromatic hydrocarbon input to urban wetlands in relation to adjacent land use. Marine Pollution Bulletin 52 (11):1355-1363. http://dx.doi.org/ 10.1016/j.marpolbul.2006.03.022

King, K. W., J . C. Balogh, K. L. Hughes, and R. D. Harmel. 2007. Nutrient load generated by storm event runoff from a golf course watershed. J ournal of Environmental Quality 36 (4):1021-1030. http:// dx.doi.org/ 10.2134/ jeq2006.0387

Konrad, C. P., D. B. Booth, and S. J . Burges. 2005. Effects of urban development in the Puget Lowland, Washington, on interannual streamflow patterns: Consequences for channel form and streambed disturbance. Water Resources Research 41 (7):1-15. http:// dx.doi.org/ 10.1029/2005WR004097

Krause, C. W., B. Lockard, T. J . Newcomb, D. Kibler, V. Lohani, and D. J . Orth. 2004. Predicting influences of urban development on thermal habitat in a warm water stream. J ournal of the American Water Resources Association 40 (6):1645-1658.

Lewis, G. P., J. D. Mitchell, C. B. Andersen, D. C. Haney, M.-K. Liao, and K. A. Sargent. 2007. Urban influences on stream chemistry and biology in the Big Brushy Creek watershed, South Carolina. Water, Air, and Soil Pollution 182 (1-4):303-323. http:// dx.doi.org/ 10.1007/ s11270-007-9340-1

Lin, Z., D. E. Radcliffe, L. M. Risse, J . J . Romeis, and C. R. J ackson. 2009. Modeling phosphorus in the Lake Allatoona watershed using SWAT: II. Effect of land use change. J ournal of Environmental Quality 38 (1):121-129. http:// dx.doi.org/ 10.2134/ jeq2007.0111

Lussier, S. M., R. W. Enser, S. N. Dasilva, and M. Charpentier. 2006. Effects of habitat disturbance from residential development on breeding bird communities in riparian corridors. Environmental Management 38 (3):504-521. http:// www.springerlink.com/ content/r5w38x7542017688/fulltext.pdf

Mahler, B. J ., P. C. Van Metre, T. J . Bashara, J . T. Wilson, and D. A. J ohns. 2005. Parking lot sealcoat: An unrecognized source of urban polycyclic aromatic hydrocarbons. Environmental Science and Technology 39 (15):5560-5566. http:// dx.doi.org/ 10.1021/ es0501565

Maliva, R. G., and K. P. Hopfensperger. 2007. Impacts of residential development on humid subtropical freshwater resources: Southwest Florida experience. J ournal of the American Water Resources Association 43 (6):1540-1549. http:// dx.doi.org/ 10.1111/j.1752-1688.2007.00126.x

Mallin, M. A., S. H. Ensign, M. R. McIver, G. C. Shank, and P. K. Fowler. 2001. Demographic, landscape, and meteorological factors controlling the microbial pollution of coastal waters. Hydrobiologia 460:185-193. http:// dx.doi.org/ 10.1023/ A: 1013169401211

McBride, M., and D. B. Booth. 2005. Urban impacts on physical stream condition: Effects of spatial scale, connectivity, and longitudinal trends. J ournal of the American Water Resources Association 41 (3):565-580. 
McKinney, M. 2008. Effects of urbanization on species richness: A review of plants and animals. Urban Ecosystems 11 (2):161-176. http:// dx.doi.org/ 10.1007/ s11252007-0045-4

Miltner, R. J., D. White, and C. Yoder. 2004. The biotic integrity of streams in urban and suburbanizing landscapes. Landscape and Urban Planning 69 (1):87-100. http:// dx.doi.org/ 10.1016/j.landurbplan.2003.10.032

Morse, C. C., A. D. Huryn, and C. Cronan. 2003. Impervious surface area as a predictor of the effects of urbanization on stream insect communities in Maine, U.S.A. Environmental Monitoring and Assessment 89 (1):95- 127. http:// dx.doi.org/ 10.1023/ A: 1025821622411

Murdock, J., D. Roelke, and F. Gelwick. 2004. Interactions between flow, periphyton, and nutrients in a heavily impacted urban stream: Implications for stream restoration effectiveness. Ecological Engineering 22 (3):197-207. http: // dx.doi.org/ 10.1016/j.ecoleng.2004.05.005

Nelson, E. J ., and D. B. Booth. 2002. Sediment sources in an urbanizing, mixed land-use watershed. J ournal of Hydrology 264 (1-4):51-68. http:// dx.doi.org/ 10.1016/ S0022-1694(02)00059-8

Nelson, P. A., J . A. Smith, and A. J . Miller. 2006. Evolution of channel morphology and hydrologic response in an urbanizing drainage basin. Earth Surface Processes and Landforms 31 (9):1063-1079. http:/ / dx.doi.org/ 10.1002/ esp.1308

Neumann, K., W. B. Lyons, E. Y. Graham, and E. Callender. 2005. Historical backcasting of metal concentrations in the Chattahoochee River, Georgia: Population growth and environmental policy. Applied Geochemistry 20 (12):2315-2324. http:// dx.doi.org/ 10.1016/j.apgeochem.2005.07.005

Ourso, R. T., and S. A. Frenzel. 2003. Identification of linear and threshold responses in streams along a gradient of urbanization in Anchorage, Alaska. Hydrobiologia 501:117-131. http:// dx.doi.org/ 10.1023/ A: 1026211808745

Palmer, S. M., B. I. Wellington, C. E. J ohnson, and C. T. Driscoll. 2005. Landscape influences on aluminium and dissolved organic carbon in streams draining the Hubbard Brook valley, New Hampshire, USA. Hydrological Processes 19 (9):1751-1769. http:/ / dx.doi.org/ 10.1002/ hyp.5660

Pankratz, S., T. Young, H. Cuevas-Arellano, R. Kumar, R. F. Ambrose, and I. H. Suffet. 2007. The ecological value of constructed wetlands for treating urban runoff. Water Science and Technology 55 (3):63-69. http:// dx.doi.org/ 10.2166/ wst.2007.073

Petersen, T. M., H. S. Rifai, M. P. Suarez, and A. R. Stein. 2005. Bacteria loads from point and nonpoint sources in an urban watershed. J ournal of Environmental Engineering 131 (10):1414-1425. http:// dx.doi.org/ 10.1061/ (ASCE)07339372(2005)131: 10(1414)

Pizzuto, J. E., W. C. Hession, and M. McBride. 2000. Comparing gravel-bed rivers in paired urban and rural catchments of southeastern Pennsylvania. Geology 28 (1):79-82. http:// dx.doi.org/ 10.1130/ 00917613(2000)028<0079: CGBRIP>2.3.CO; 2 
Pomeroy, C. A., N. A. Postel, P. A. O'Neill, and L. A. Roesner. 2008. Development of storm-water management design criteria to maintain geomorphic stability in Kansas City metropolitan area streams. J ournal of Irrigation and Drainage Engineering 134 (5):562-566. http:// dx.doi.org/ 10.1061/ (ASCE)07339437(2008)134:5(562)

Price, K., and D. S. Leigh. 2006. Comparative water quality of lightly- and moderatelyimpacted streams in the Southern Blue Ridge Mountains, USA. Environmental Monitoring and Assessment 120 (1-3):269-300. http:/ / dx.doi.org/ 10.1007/ s10661-005-9060-1

Richards, R. P., D. B. Baker, J . P. Crumrine, J . W. Kramer, D. E. Ewing, and B. J . Merryfield. 2008. Thirty-year trends in suspended sediment in seven Lake Erie tributaries. J ournal of Environmental Quality 37 (5):1894-1908. http:/ / dx.doi.org/ 10.2134/ jeq2007.0590

Rose, S. 2002. Comparative major ion geochemistry of Piedmont streams in the Atlanta, Georgia region: Possible effects of urbanization. Environmental Geology 42 (1):102-113. http:/ / dx.doi.org/ 10.1007/ s00254-002-0545-8

- 2007. The effects of urbanization on the hydrochemistry of base flow within the Chattahoochee River Basin (Georgia, USA). J ournal of Hydrology 341 (1-2):4254. http:// dx.doi.org/ 10.1016/j.jhydrol.2007.04.019

Rose, S., M. S. Crean, D. K. Sheheen, and A. M. Ghazi. 2001. Comparative zinc dynamics in Atlanta metropolitan region stream and street runoff. Environmental Geology 40 (8):983-992. http:// dx.doi.org/ 10.1007/ s002540100285

Roy, A. H., and W. D. Shuster. 2009. Assessing impervious surface connectivity and applications for watershed management. J ournal of the American Water Resources Association 45 (1):198-209. http: / / dx.doi.org/ 10.1111/j.17521688.2008.00271.x

Ryan, R. J., and A. I. Packman. 2006. Changes in streambed sediment characteristics and solute transport in the headwaters of Valley Creek, an urbanizing watershed. J ournal of Hydrology 323 (1-4):74-91. http:// dx.doi.org/ 10.1016/j.jhydrol.2005.06.042

Schnaiberg, J ., J . Riera, M. G. Turner, and P. R. Voss. 2002. Explaining human settlement patterns in a recreational lake district: Vilas County, Wisconsin, USA. Environmental Management 30 (1):24-34. http:// dx.doi.org/ 10.1007/ s00267002-2450-z

Schoonover, J. E., and B. G. Lockaby. 2006. Land cover impacts on stream nutrients and fecal coliform in the lower Piedmont of West Georgia. J ournal of Hydrology 331 (3-4):371-382. http:// dx.doi.org/ 10.1016/j.jhydrol.2006.05.031

Schoonover, J. E., B. G. Lockaby, and J . N. Shaw. 2007. Channel morphology and sediment origin in streams draining the Georgia Piedmont. J ournal of Hydrology 342 (1-2):110-123. http:// dx.doi.org/ 10.1016/j.jhydrol.2007.05.017 
Seilheimer, T., A. Wei, P. Chow-Fraser, and N. Eyles. 2007. Impact of urbanization on the water quality, fish habitat, and fish community of a Lake Ontario marsh, Frenchman's Bay. Urban Ecosystems 10 (3):299-319. http://dx.doi.org/ 10.1007/ s11252-007-0028-5

Simmons, M. E., X. B. Wu, and S. G. Whisenant. 2007. Bottomland hardwood forest species responses to flooding regimes along an urbanization gradient. Ecological Engineering 29 (3):223-231. http:// dx.doi.org/ 10.1016/j.ecoleng.2006.07.005

Snyder, C. D., J . A. Young, R. Villella, and D. P. Lemarie. 2003. Influences of upland and riparian land use patterns on stream biotic integrity. Landscape Ecology 18 (7):647-664. http:// dx.doi.org/ 10.1023/ B: LAND.0000004178.41511.da

Sonoda, K., J . A. Yeakley, and C. E. Walker. 2001. Near-stream landuse effects on streamwater nutrient distribution in an urbanizing watershed. J ournal of the American Water Resources Association 37 (6):1517-1532.

Southerland, M. 2004. Environmental impacts of dispersed development from federal infrastructure projects. Environmental Monitoring and Assessment 94 (1):163178. http:// dx.doi.org/ 10.1023/ B: EMAS.0000016886.16085.39

Stanhope, J. W., I. C. Anderson, and W. G. Reay. 2009. Base flow nutrient discharges from lower Delmarva Peninsula watersheds of Virginia, USA. J ournal of Environmental Quality 38 (5):2070-2083. http: / / dx.doi.org/ 10.2134/ jeq2008.0358

Stein, E. D., and V. K. Yoon. 2008. Dry weather flow contribution of metals, nutrients, and solids from natural catchments. Water, Air, and Soil Pollution 190 (1-4):183195. http:// dx.doi.org/ 10.1007/ s11270-007-9591-x

Tavernia, B. G., and J . M. Reed. 2009. Spatial extent and habitat context influence the nature and strength of relationships between urbanization measures. Landscape and Urban Planning 92 (1):47-52.

http:// dx.doi.org/ 10.1016/j.landurbplan.2009.02.003

Toran, L., and D. Grandstaff. 2007. Variation of nitrogen concentrations in stormpipe discharge in a residential watershed. J ournal of the American Water Resources Association 43 (3):630-641. http:/ / dx.doi.org/ 10.1111/j.1752-1688.2007.00050.x

Trauth, K. M., and Y.-S. Shin. 2005. Implementation of the EPA's water quality trading policy for storm water management and smart growth. J ournal of Urban Planning and Development 131 (4):258-269. http:// dx.doi.org/ 10.1061/ (ASCE)0733-9488(2005)131:4(258)

Tuccillo, M. E. 2006. Size fractionation of metals in runoff from residential and highway storm sewers. Science of the Total Environment 355 (1-3):288-300. http:/ / dx.doi.org/ 10.1016/j.scitotenv.2005.03.003

Tufford, D. L., C. L. Samarghitan, H. N. McKellar Jr, D. E. Porter, and J . R. Hussey. 2003. Impacts of urbanization on nutrient concentrations in small southeastern coastal streams. J ournal of the American Water Resources Association 39 (2):301-312.

Urbonas, B. R., and J . T. Doerfer. 2005. Master planning for stream protection in urban watersheds. Water Science and Technology 51(2):239-247. 
Vokral, J ., D. Gumb, A. D. Cavallaro, S. Mehrotra, and E. Rosenberg. 2003. Wetlands at work. Civil Engineering 73 (2):56-63.

Walsh, S. E., P. A. Soranno, and D. T. Rutledge. 2003. Lakes, wetlands, and streams as predictors of land use/ cover distribution. Environmental Management 31 (2):198-214. http:// dx.doi.org/ 10.1007/ s00267-002-2833-1

Walters, D. M., D. S. Leigh, and A. B. Bearden. 2003. Urbanization, sedimentation, and the homogenization of fish assemblages in the Etowah River Basin, USA. Hydrobiologia 494:5-10. http:// dx.doi.org/ 10.1023/ A: 1025412804074

Walters, D. M., A. H. Roy, and D. S. Leigh. 2009. Environmental indicators of macroinvertebrate and fish assemblage integrity in urbanizing watersheds. Ecological Indicators 9 (6): 1222-1233.

http:// dx.doi.org/ 10.1016/j.ecolind.2009.02.011

Webb, P. W. 2008. The impact of changes in water level and human development on forage fish assemblages in great lakes coastal marshes. J ournal of Great Lakes Research 34 (4):615-630. http: / / dx.doi.org/ 10.3394/ 0380-1330-34.4.615

Weston, N. B., J. T. Hollibaugh, and S. B. J oye. 2009. Population growth away from the coastal zone: Thirty years of land use change and nutrient export in the Altamaha River, GA. Science of the Total Environment 407 (10):3347-3356. http:// dx.doi.org/ 10.1016/j.scitotenv.2008.12.066

White, M. D., and K. A. Greer. 2006. The effects of watershed urbanization on the stream hydrology and riparian vegetation of Los Penasquitos Creek, California. Landscape and Urban Planning 74 (2):125-138. http:/ / dx.doi.org/ 10.1016/j.landurbplan.2004.11.015

Wolter, P. T., C. A. J ohnston, and G. J . Niemi. 2006. Land use land cover change in the U.S. Great Lakes basin 1992 to 2001. J ournal of Great Lakes Research 32 (3):607-628.

Wright, T., J . Tomlinson, T. Schueler, K. Cappiella, A. Kitchell, and D. Hirschman. 2006. Direct and indirect impacts of urbanization on wetland water quality, ed. Center for Watershed Protection. Ellicott City, MD 21043: C. F. W. Protection, N. F. 8390 Main Street and M. Ellicott City. 


\section{Appendix E: Ecological Integrity Assessment}

Barbour, M. T., W. F. Swietlik, S. K. Jackson, D. L. Courtemanch, S. P. Davies, and C. O. Yoder. 2000. Measuring the attainment of biological integrity in the USA: A critical element of ecological integrity. Hydrobiologia 422-423 (0):453-464. http: // dx.doi.org/ 10.1023/ A: 1017095003609

Bateman, B., and E. Walbeck. 2004. The public policy aspects of biological monitoring: Budget and land-use planning implications at the county level. Environmental Monitoring and Assessment 94 (1):193-204. http:// dx.doi.org/ 10.1023/ B:EMAS.0000016888.33049.39

Beighley, R. E., and Y. He. 2009. Predicting model uncertainty at river junctions due to drainage network structure. J ournal of Hydrologic Engineering 14 (5):499-507. http:// dx.doi.org/ 10.1061/ (ASCE)HE.1943-5584.0000007

Bhagat, Y., J . J . H. Ciborowski, L. B. J ohnson, D. G. Uzarski, T. M. Burton, S. T. A. Timmermans, and M. J . Cooper. 2007. Testing a fish index of biotic integrity for responses to different stressors in Great Lakes coastal wetlands. J ournal of Great Lakes Research 33 (SPEC. ISS. 3):224-235. http:// dx.doi.org/ 10.3394/ 03801330(2007)33[224:TAFIOB]2.0.CO; 2

-2009. Testing a fish index of biotic integrity for responses to different stressors in Great Lakes coastal wetlands. J ournal of Great Lakes Research 33 (SUPPL. 2): 224-235. http:/ / dx.doi.org/ 10.3394/ 0380-1330(2007)33[224:TAFIOB]2.0.CO; 2

Blocksom, K. A., J . P. Kurtenbach, D. J . Klemm, F. A. Fulk, and S. M. Cormier. 2002. Development and evaluation of the lake macroinvertebrate integrity index (LMII) for New J ersey lakes and reservoirs. Environmental Monitoring and Assessment 77 (3):311-333. http:/ / dx.doi.org/ 10.1023/ A: 1016096925401

Brisbois, M. C., R. J amieson, R. Gordon, G. Stratton, and A. Madani. 2008. Stream ecosystem health in rural mixed land-use watersheds. J ournal of Environmental Engineering and Science 7 (5):439-452. http:// dx.doi.org/ 10.1139/ S08-016

Brooks, R. P., D. H. Wardrop, and C. A. Cole. 2006. Inventorying and monitoring wetland condition and restoration potential on a watershed basis with examples from Spring Creek Watershed, Pennsylvania, USA. Environmental Management 38 (4):673-687. http:// www.springerlink.com/ content/ 886r2h861730k520/fulltext.pdf

Carlisle, D. M., J . Falcone, and M. R. Meador. 2009. Predicting the biological condition of streams: Use of geospatial indicators of natural and anthropogenic characteristics of watersheds. Environmental Monitoring and Assessment 151 (1-4):143-160. http:// dx.doi.org/ 10.1007/ s10661-008-0256-z

Chang, H.-H. 2008. River morphology and river channel changes. Transactions of Tianjin University 14 (4):254-262. http:// dx.doi.org/ 10.1007/ s12209-0080045-3 
Cohen, M. J ., C. R. Lane, K. C. Reiss, J . A. Surdick, E. Bardi, and M. T. Brown. 2005. Vegetation based classification trees for rapid assessment of isolated wetland condition. Ecological Indicators 5 (3):189-206.

http: // www.sciencedirect.com/ science?_ob=MImg\&_imagekey=B6W874G1PKM8-1-

$1 \&$ _cdi $=6647 \&$ user $=930810 \&$ \& orig $=$ search\&_coverDate $=08 \% 2 F 31 \% 2 F 2005 \&$ sk $=999949996 \& v i e w=c \& w c h p=d G L z V z z-$

zSkWz\&md5=d0df28b043a028d325e8379de7786ab2\&ie=/sdarticle.pdf

Cole, M. L., I. Valiela, K. D. Kroeger, G. L. Tomasky, J . Cebrian, C. Wigand, R. A. McKinney, S. P. Grady, and M. H. Carvalho Da Silva. 2004. Assessment of a 15N isotopic method to indicate anthropogenic eutrophication in aquatic ecosystems. J ournal of Environmental Quality 33 (1):124-132.

Craft, C., K. Krull, and S. Graham. 2007. Ecological indicators of nutrient enrichment, freshwater wetlands, Midwestern United States (U.S.). Ecological Indicators 7 (4):733-750. http:// dx.doi.org/ 10.1016/j.ecolind.2006.08.004

DeKeyser, E. S., M. Biondini, D. Kirby, and C. Hargiss. 2009. Low prairie plant communities of wetlands as a function of disturbance: Physical parameters. Ecological Indicators 9 (2):296-306. http:/ / dx.doi.org/ 10.1016/j.ecolind.2008.05.003

Drohan, P. J ., E. J . Ciolkosz, and G. W. Petersen. 2003. Soil survey mapping unit accuracy in forested field plots in northern Pennsylvania. Soil Science Society of America J ournal 67 (1):208-214.

Epstein, C. M. 2002. Application of Rosgen analysis to the NewJ ersey Pine Barrens. J ournal of the American Water Resources Association 38 (1):69-78.

Ervin, G. N., B. D. Herman, J. T. Bried, and D. C. Holly. 2006. Evaluating non-native species and wetland indicator status as components of wetlands floristic assessment. Wetlands 26 (4):1114-1129.

Guntenspergen, G. R., S. A. Peterson, S. G. Leibowitz, and L. M. Cowardin. 2002. Indicators of wetland condition for the prairie pothole region of the United States. Environmental Monitoring and Assessment 78 (3):229-252. http:// dx.doi.org/ 10.1023/ A: 1019982818231

Hannaford, M. J . 1999. Development and Comparison of Biological Indicators of Habitat Disturbance for Streams and Wetlands.

Hargiss, C. L. M., E. S. DeKeyser, D. R. Kirby, and M. J . Ell. 2008. Regional assessment of wetland plant communities using the index of plant community integrity. Ecological Indicators 8 (3):303-307. http:// www.sciencedirect.com/science?_ob=MImg\&_imagekey=B6W874NH6N9T-1-

$2 \&$ _cdi $=6647 \&$ _ user $=930810 \&$ \& orig $=$ search\&_coverDate $=05 \% 2 \mathrm{~F} 31 \% 2 \mathrm{~F} 2008 \&$ sk $=999919996 \overline{6}$ view $=$ c\&wchp $=$ dGLzVlzzSkWb\&md5=ab2ef13745b868916f477097c8b3df1c\&ie=/ sdarticle.pdf

Hartley, D. M., and D. E. Funke. 2001. Techniques for detecting hydrologic change in high resource streams. J ournal of the American Water Resources Association 37 (6):1589-1595. 
Hartzell, D., J . R. Bidwell, and C. A. Davis. 2007. A comparison of natural and created depressional wetlands in central Oklahoma using metrics from indices of biological integrity. Wetlands 27 (4):794-805. http:/ / dx.doi.org/ 10.1672/ 02775212(2007)27[794:ACONAC]2.0.CO; 2

Herlihy, A. T., J . Sifneos, C. Bason, A. J acobs, M. E. Kentula, and M. S. Fennessy. 2009. An approach for evaluating the repeatability of rapid wetland assessment methods: The effects of training and experience. Environmental Management 44 (2):369-377. http:// dx.doi.org/ 10.1007/ s00267-009-9316-6

Hughes, R. M., S. G. Paulsen, and J . L. Stoddard. 2000. EMAP-Surface Waters: A multiassemblage, probability survey of ecological integrity in the U.S.A. Hydrobiologia 422-423 (0):429-443. http:// dx.doi.org/ 10.1023/ A: 1017029107669

King, R. S., K. T. Nunnery, and C.J . Richardson. 2000. Macroinvertebrate assemblage response to highway crossings in forested wetlands: implications for biological assessment. Wetlands Ecology and Management 8 (4):243-256.

http:// dx.doi.org/ 10.1023/ A: 1008479316066

Liu, Z.-J ., D. E. Weller, T. E. J ordan, D. L. Correll, and K. B. Boomer. 2008. Integrated modular modeling of water and nutrients from point and nonpoint sources in the Patuxent River watershed. J ournal of the American Water Resources Association 44 (3): 700-723. http:/ / dx.doi.org/ 10.1111/j.17521688.2008.00200.x

Loheide Ii, S. P., and S. M. Gorelick. 2006. Quantifying stream-aquifer interactions through the analysis of remotely sensed thermographic profiles and in situ temperature histories. Environmental Science and Technology 40 (10):33363341. http: / / dx.doi.org/ 10.1021/ es0522074

Meador, M. R., D. M. Carlisle, and J . F. Coles. 2008. Use of tolerance values to diagnose water-quality stressors to aquatic biota in New England streams. Ecological Indicators 8 (5):718-728. http:// dx.doi.org/ 10.1016/j.ecolind.2008.01.002

Mills, C. 2003. Conservation agency battles erosion, preserves wetlands with CAD. Public Works 134 (4):14-17.

O'Connor, R. J., T. E. Walls, and R. M. Hughes. 2000. Using multiple taxonomic groups to index the ecological condition of lakes. Environmental Monitoring and Assessment 61 (2):207-229. http:// dx.doi.org/ 10.1023/ A: 1006119205583

Peterson, A. C., and G. J . Niemi. 2007. Evaluation of the Ohio rapid assessment method for wetlands in the western Great Lakes: An analysis using bird communities. J ournal of Great Lakes Research 33:280-291.

Price, S. J ., R. W. Howe, J . M. Hanowski, R. R. Regal, G. J. Niemi, and C. R. Smith. 2007. Are Anurans of Great Lakes coastal wetlands reliable indicators of ecological condition. J ournal of Great Lakes Research 33 (sp3):211-223. http:/ / dx.doi.org/ 10.3394/ 0380-1330(2007)33[211:AAOGLC]2.0.CO; 2

Radwell, A. J ., and T. J . Kwak. 2005. Assessing ecological integrity of Ozark rivers to determine suitability for protective status. Environmental Management 35 (6):799-810. http:/ / dx.doi.org/ 10.1007/ s00267-004-0136-4 
Reiss, K. C. 2006. Florida Wetland Condition Index for depressional forested wetlands. Ecological Indicators 6 (2):337-352. http:// dx.doi.org/ 10.1016/j.ecolind.2005.03.013

Simon, A., M. Doyle, M. Kondolf, F. D. Shields Jr., B. Rhoads, and M. McPhillips. 2007. Critical evaluation of how the Rosgen classification and associated "natural channel design" methods fail to integrate and quantify fluvial processes and channel response. J ournal of the American Water Resources Association 43 (5):1117-1131.

Smiley, P. C., Jr., and E. D. Dibble. 2008. Influence of spatial resolution on assessing channelization impacts on fish and macroinvertebrate communities in a warmwater stream in the southeastern United States. Environmental Monitoring and Assessment 138 (1-3):17-29. http:// dx.doi.org/ 10.1007/ s10661-007-9787-y

Smiley, P. C., J r., and E. D. Dibble. 2008. Influence of spatial resolution on assessing channelization impacts on fish and macroinvertebrate communities in a warmwater stream in the southeastern United States. Environmental Monitoring and Assessment 138 (1-3):17-29.

Smyth, R. L., M. C. Watzin, and R. E. Manning. 2007. Defining acceptable levels for ecological indicators: An approach for considering social values. Environmental Management 39 (3):301-315. http:/ / dx.doi.org/ 10.1007/ s00267-005-0282-3

Spieles, D. J., and J . W. Mora. 2007. Detrital decomposition as a measure of ecosystem function in created wetlands. J ournal of Freshwater Ecology 22 (4):571-579.

Spruill, C. A., S. R. Workman, and J . L. Taraba. 2000. Simulation of daily and monthly stream discharge from small watersheds using the SWAT model. Transactions of the American Society of Agricultural Engineers 43 (6):1431-1439.

Strain, G. F., R. L. Raesly, and R. H. Hilderbrand. 2009. A comparison of techniques to sample salamander assemblages along highland streams of Maryland. Environmental Monitoring and Assessment 156 (1-4):1-16. http:// dx.doi.org/ 10.1007/s10661-008-0459-3

Teels, B. M., L. E. Mazanti, and C. A. Rewa. 2004. Using an IBI to assess effectiveness of mitigation measures to replace loss of a wetland-stream ecosystem. Wetlands 24 (2):375-384.

Thoma, D. P., S. C. Gupta, M. E. Bauer, and C. E. Kirchoff. 2005. Airborne laser scanning for riverbank erosion assessment. Remote Sensing of Environment 95 (4):493501. http:// dx.doi.org/ 10.1016/j.rse.2005.01.012

Tran, L. T., C. G. Knight, R. V. O'Neill, E. R. Smith, and M. O'Connell. 2003. Selforganizing maps for integrated environmental assessment of the Mid-Atlantic region. Environmental Management 31 (6):822-835.

http:// dx.doi.org/ 10.1007/ s00267-003-2917-6

VÃ, lstad, J. H., N. E. Roth, G. Mercurio, M. T. Southerland, and D. E. Strebel. 2003. Using environmental stressor information to predict the ecological status of Maryland non-tidal streams as measured by biological indicators. Environmental Monitoring and Assessment 84 (3):219-242.

http:// dx.doi.org/ 10.1023/ A: 1023374524254 
Wang, L., D. M. Robertson, and P. J . Garrison. 2007. Linkages between nutrients and assemblages of macroinvertebrates and fish in wadeable streams: Implication to nutrient criteria development. Environmental Management 39 (2):194-212. http:// dx.doi.org/ 10.1007/ s00267-006-0135-8

Warren, D. R., W. S. Keeton, and C. E. Kraft. 2008. A comparison of line-intercept and census techniques for assessing large wood volume in streams. Hydrobiologia 598 (1):123-130. http:/ / dx.doi.org/ 10.1007/ s10750-007-9144-8

Whiles, M. R., B. L. Brock, A. C. Franzen, and S. C. Dinsmore, II. 2000. Stream invertebrate communities, water quality, and land-use patterns in an agricultural drainage basin of northeastern Nebraska, USA. Environmental Management 26 (5):563-576. http: // dx.doi.org/ 10.1007/ s002670010113

Wilcox, D. A., J . E. Meeker, P. L. Hudson, B. J . Armitage, M. G. Black, and D. G. Uzarski. 2002. Hydrologic variability and the application of index of biotic integrity metrics to wetlands: A Great Lakes evaluation. Wetlands 22 (3):588-615. http:/ / dx.doi.org/ 10.1672/ 0277-5212(2002)022[0588:HVATAO]2.0.CO; 2

Wilhelm, J . G. O., J . D. Allan, K. J. Wessell, R. W. Merritt, and K. W. Cummins. 2005. Habitat assessment of non-wadeable rivers in Michigan. Environmental Management 36 (4):592-609. http:// dx.doi.org/ 10.1007/ s00267-004-0141-7

Williams, M. R., T. R. Fisher, W. R. Boynton, C. F. Cerco, M. W. Kemp, K. N. Eshleman, S. C. Kim, R. R. Hood, D. A. Fiscus, and G. R. Radcliffe. 2006. An integrated modelling system for management of the Patuxent River estuary and basin, Maryland, USA. International J ournal of Remote Sensing 27 (17):3705-3726. http:/ / dx.doi.org/ 10.1080/ 01431160500500417

Winger, P. V., P. J . Lasier, and K. J . Bogenrieder. 2005. Combined use of rapid bioassessment protocols and sediment quality triad to assess stream quality. Environmental Monitoring and Assessment 100 (1-3):267-295. http:// dx.doi.org/ 10.1007/ s10661-005-7788-2 


\section{Appendix F: Erosion, Scour and Sedimentation}

Agouridis, C. T., D. R. Edwards, S. R. Workman, J . R. Bicudo, B. K. Koostra, E. S. Vanzant, and J. L. Taraba. 2005. Streambank erosion associated with grazing practices in the humid region. Transactions of the American Society of Agricultural Engineers 48 (1):181-190.

Allmendinger, N. E., J. E. Pizzuto, G. E. Moglen, and M. Lewicki. 2007. A sediment budget for an urbanizing watershed, 1951-1996, Montgomery County, Maryland, U.S.A. J ournal of the American Water Resources Association 43 (6):1483-1498. http:// dx.doi.org/ 10.1111/j.1752-1688.2007.00122.x

Balogh, S. J., E. B. Swain, and Y. H. Nollet. 2006. Elevated methylmercury concentrations and loadings during flooding in Minnesota rivers. Science of the Total Environment 368 (1):138-148. http:/ / dx.doi.org/ 10.1016/j.scitotenv.2005.09.045

Blanco-Canqui, H., C. J . Gantzer, S. H. Anderson, E. E. Alberts, and A. L. Thompson. 2004. Grass barrier and vegetative filter strip effectiveness in reducing runoff, sediment, nitrogen, and phosphorus loss. Soil Science Society of America J ournal 68 (5):1670-1678.

Brown, B. V., H. M. Valett, and M. E. Schreiber. 2007. Arsenic transport in groundwater, surface water, and the hyporheic zone of a mine-influenced stream-aquifer system. Water Resources Research 43 (11). http: / / dx.doi.org/ 10.1029/ 2006WR005687

Carroll, R. W. H., J . J . Warwick, A. I. J ames, and J . R. Miller. 2004. Modeling erosion and overbank deposition during extreme flood conditions on the Carson River, Nevada. J ournal of Hydrology 297 (1-4):1-21. http:// dx.doi.org/ 10.1016/j.jhydrol.2004.04.012

Clark, S. E., A. A. Allison, and R. A. Sitler. 2009. Geographic variability of rainfall erosivity estimation and impact on construction site erosion control design. J ournal of Irrigation and Drainage Engineering 135 (4):474-479. http:/ / dx.doi.org/ 10.1061/ (ASCE)IR.1943-4774.0000017

Comoss, E. J., D. A. Kelly, and H. Z. Leslie. 2001. Innovative erosion control along the lake erie shoreline. Urban Beaches Balancing Public Rights and Private Development 4:31-38.

Conroy, W. J., R. H. Hotchkiss, and W. J . Elliot. 2006. A coupled upland-erosion and instream hydrodynamic-sediment transport model for evaluating sediment transport in forested watersheds. Transactions of the ASABE 49 (6):1713-1722.

Cowie, P. A., A. C. Whittaker, M. Attal, G. Roberts, G. E. Tucker, and A. Ganas. 2008. New constraints on sediment-flux-dependent river incision: Implications for extracting tectonic signals from river profiles. Geology 36 (7):535-538. http:// dx.doi.org/ 10.1130/ G24681A.1 
Dabney, S. M., F. D. Shields J r, D. M. Temple, and E. J . Langendoen. 2004. Erosion processes in gullies modified by establishing grass hedges. Transactions of the American Society of Agricultural Engineers 47 (5):1561-1571.

Demissie, M., L. Keefer, J. Slowikowski, and K. Stevenson. 2006. Evaluating the effectiveness of the Illinois River Conservation Reserve Enhancement Program in reducing sediment delivery. IAHS-AISH Publication (306):295-303.

Doten, C. O., L. C. Bowling, J . S. Lanini, E. P. Maurer, and D. P. Lettenmaier. 2006. A spatially distributed model for the dynamic prediction of sediment erosion and transport in mountainous forested watersheds. Water Resources Research 42 (4). http:// dx.doi.org/ 10.1029/ 2004WR003829

Greimann, B., Y. Lai, and J . Huang. 2008. Two-dimensional total sediment load model equations. J ournal of Hydraulic Engineering 134 (8):1142-1146. http:// dx.doi.org/ 10.1061/ (ASCE)0733-9429(2008)134:8(1142)

Gupta, V. K. 2004. Emergence of statistical scaling in floods on channel networks from complex runoff dynamics. Chaos, Solitons and Fractals 19 (2):357-365. http:/ / dx.doi.org/ 10.1016/ S0960-0779(03)00048-1

Hassan, M. A., D. L. Hogan, S. A. Bird, C. L. May, T. Gomi, and D. Campbell. 2005. Spatial and temporal dynamics of wood in headwater streams of the Pacific northwest. J ournal of the American Water Resources Association 41 (4):899919.

Herrman, K. S., and J . R. White. 2008. Denitrification in intact sediment cores from a constructed wetland: Examining the isotope pairing technique. Applied Geochemistry 23 (8):2105-2112. http:// dx.doi.org/ 10.1016/j.apgeochem.2008.04.024

Houser, J . N., P. J . Mulholland, and K. O. Maloney. 2006. Upland disturbance affects headwater stream nutrients and suspended sediments during baseflow and stormflow. J ournal of Environmental Quality 35 (1):352-365. http:/ / dx.doi.org/ 10.2134/ jeq2005.0102

J ennings, A. A. 2003. Modeling sedimentation and scour in small urban lakes. Environmental Modelling and Software 18 (3):281-291. http:// dx.doi.org/ 10.1016/S1364-8152(02)00074-9

Jiang, J ., N. K. Ganju, and A. J . Mehta. 2004. Estimation of contraction scour in riverbed using SERF. J ournal of Waterway, Port, Coastal and Ocean Engineering 130 (4):215-218. http:// dx.doi.org/ 10.1061/ (ASCE)0733-950X(2004)130:4(215)

J ohnson, J. P., and K. X. Whipple. 2007. Feedbacks between erosion and sediment transport in experimental bedrock channels. Earth Surface Processes and Landforms 32 (7):1048-1062. http: / dx.doi.org/ 10.1002/ esp.1471

Koel, T. M., and K. E. Stevenson. 2002. Effects of dredge material placement on benthic macroinvertebrates of the Illinois River. Hydrobiologia 474:229-238. http:// dx.doi.org/ 10.1023/ A: 1016500324467 
Koken, M., and G. Constantinescu. 2008. An investigation of the flow and scour mechanisms around isolated spur dikes in a shallow open channel: 2 . Conditions corresponding to the final stages of the erosion and deposition process. Water Resources Research 44 (8). http:// dx.doi.org/ 10.1029/2007WR006491

Lamb, T. A., T. S. J ones, and Anonymous. 2008. Impact of all-terrain-vehicle (atv) trail crossings on stream quality, Little Sequatchie River, TN. Abstracts with Programs - Geological Society of America, vol. 41, no. 1, pp.44, Mar 2008.

Langendoen, E. J ., and A. Simon. 2008. Modeling the evolution of incised streams. II: Streambank erosion. J ournal of Hydraulic Engineering 134 (7):905-915. http:// dx.doi.org/ 10.1061/ (ASCE)0733-9429(2008)134: 7(905)

Lockaby, B. G., R. Governo, E. Schilling, G. Cavalcanti, and C. Hartsfield. 2005. Wetlands and aquatic processes: Effects of sedimentation on soil nutrient dynamics in riparian forests. J ournal of Environmental Quality 34 (1):390-396.

Lopez S, J . L. 2004. Channel response to gravel mining activities in mountain rivers. J ournal of Mountain Science 1 (3):264-269. http:// dx.doi.org/ 10.1007/BF02919330

Magner, J . A., and K. N. Brooks. 2008. Predicting stream channel erosion in the lacustrine core of the upper Nemadji River, Minnesota (USA) using stream geomorphology metrics. Environmental Geology 54 (7):1423-1434. http:// dx.doi.org/ 10.1007/ s00254-007-0923-3

Markus, M., and M. Demissie. 2006. Predictability of annual sediment loads based on flood events. J ournal of Hydrologic Engineering 11 (4):354-361. http:// dx.doi.org/ 10.1061/ (ASCE)1084-0699(2006)11:4(354)

May, C. L., B. Pryor, T. E. Lisle, and M. Lang. 2009. Coupling hydrodynamic modeling and empirical measures of bed mobility to predict the risk of scour and fill of salmon redds in a large regulated river. Water Resources Research 45 (5). http:/ / dx.doi.org/ 10.1029/ 2007WR006498

McCaleb, M. M., and R. A. McLaughlin. 2008. Sediment trapping by five different sediment detention devices on construction sites. Transactions of the ASABE 51(5):1613-1621.

Merwade, V., F. Olivera, M. Arabi, and S. Edleman. 2008. Uncertainty in flood inundation mapping: Current issues and future directions. J ournal of Hydrologic Engineering 13 (7):608-620. http:// dx.doi.org/ 10.1061/ (ASCE)10840699(2008)13: 7(608)

Negley, T. L., and K. N. Eshleman. 2006. Comparison of stormflow responses of surfacemined and forested watersheds in the Appalachian Mountains, USA. Hydrological Processes 20 (16):3467-3483. http:// dx.doi.org/ 10.1002/ hyp.6148

Norton, S. A., K. Coolidge, A. Amirbahman, R. Bouchard, J . Kopacek, and R. Reinhardt. 2008. Speciation of $\mathrm{Al}, \mathrm{Fe}$, and $\mathrm{P}$ in recent sediment from three lakes in Maine, USA. Science of the Total Environment 404 (2-3):276-283. http:// dx.doi.org/ 10.1016/j.scitotenv.2008.03.016 
Olive, N. D., and J . L. Marion. 2009. The influence of use-related, environmental, and managerial factors on soil loss from recreational trails. J ournal of Environmental Management 90 (3):1483-1493.

http:// www.sciencedirect.com/science?_ob=MImg\&_imagekey=B6WJ 74V2PSYW-1-

1\&_cdi $=6871 \&$ _ user $=930810 \&$ _ orig $=$ search\&_coverDate $=03 \% 2 \mathrm{~F} 31 \% 2 \mathrm{~F} 2009 \&$ sk $=999099996 \& v i e w=c \& w c h p=d G L b V l z-$

zSkzS\&md5=e3510da7b422f571a097bbb486fe5919\&ie=/ sdarticle.pdf

Ricker, M. C., B. K. Odhiambo, and J . M. Church. 2008. Spatial analysis of soil erosion and sediment fluxes: A paired watershed study of two Tappahannock River tributaries, Stafford County, Virginia. Environmental Management 41 (5): 766778. http:/ / dx.doi.org/ 10.1007/ s00267-008-9094-6

Rojas, R., M. Velleux, P. Y. J ulien, and B. E. J ohnson. 2008. Grid scale effects on watershed soil erosion models. J ournal of Hydrologic Engineering 13 (9): $793-$ 802. http:// dx.doi.org/ 10.1061/ (ASCE)1084-0699(2008)13:9(793)

Schlacher, T., D. Richardson, and I. McLean. 2008. Impacts of off-road vehicles (ORVs) on macrobenthic assemblages on sandy beaches. Environmental Management 41(6):878-892. http:// dx.doi.org/ 10.1007/ s00267-008-9071-0

Shields, F. D., and C. M. Cooper. 2000. Woody vegetation and debris for in-channel sediment control. International J ournal of Sediment Research 15 (1):83-92.

Simon, A., and L. Klimetz. 2008. Magnitude, frequency, and duration relations for suspended sediment in stable ("reference") Southeastern streams. J ournal of the American Water Resources Association 44 (5): 1270-1283. http:// dx.doi.org/ 10.1111/j.1752-1688.2008.00222.x

Slutzman, J . E., and J . A. Smith. 2006. Effects of flood control structures on flood response for hurricane floyd in the Brandywine creek watershed, Pennsylvania. J ournal of Hydrologic Engineering 11 (5):432-441. http:// dx.doi.org/ 10.1061/ (ASCE)1084-0699(2006)11:5(432)

Stockstill, R. L., and R. C. Berger. 2001. Simulating barge drawdown and currents in channel and backwater areas. J ournal of Waterway, Port, Coastal and Ocean Engineering 127 (5):290-298. http:// dx.doi.org/ 10.1061/ (ASCE)0733950X(2001) 127:5(290)

Thoma, D. P., S. C. Gupta, M. E. Bauer, and C. E. Kirchoff. 2005. Airborne laser scanning for riverbank erosion assessment. Remote Sensing of Environment 95 (4):493501. http:// dx.doi.org/ 10.1016/j.rse.2005.01.012

Thomas, J. T., N. R. Iverson, M. R. Burkart, and L. A. Kramer. 2004. Long-term growth of a valley-bottom gully, Western Iowa. Earth Surface Processes and Landforms 29 (8):995-1009. http:// dx.doi.org/ 10.1002/ esp.1084

Wang, P., and L. C. Linker. 2008. Improvement of regression simulation in fluvial sediment loads. J ournal of Hydraulic Engineering 134 (10):1527-1531. http:// dx.doi.org/ 10.1061/(ASCE)0733-9429(2008)134: 10(1527) 
Welsh, M. J ., L. H. MacDonald, E. Brown, and Z. Libohova. 2006. Erosion and sediment delivery from unpaved roads and off-highway vehicle (OHV) trails in the upper South Platte River Watershed, Colorado. 2000 Florida Ave., N.W. Washington DC 20009 USA, [URL:http://www.agu.org]: American Geophysical Union.

Wilkinson, B. H., and B. J . McElroy. 2007. The impact of humans on continental erosion and sedimentation. Bulletin of the Geological Society of America 119 (1-2):140156. http: / / dx.doi.org/ 10.1130/ B25899.1

Wilson, T. A., S. A. Norton, B. A. Lake, and A. Amirbahman. 2008. Sediment geochemistry of $\mathrm{Al}, \mathrm{Fe}$, and $\mathrm{P}$ for two historically acidic, oligotrophic Maine lakes. Science of the Total Environment 404 (2-3):269-275.

http:/ / dx.doi.org/ 10.1016/j.scitotenv.2008.06.061 


\section{Appendix G: Mercury and Other Heavy Metals}

Andrews, S., and R. A. Sutherland. 2004. Cu, Pb and Zn contamination in Nuuanu watershed, Oahu, Hawaii. Science of the Total Environment 324 (1-3):173-182. http:// dx.doi.org/ 10.1016/j.scitotenv.2003.10.032

Balogh, S. J ., Y. Huang, H. J . Offerman, M. L. Meyer, and D. K. J ohnson. 2003. Methylmercury in rivers draining cultivated watersheds. Science of the Total Environment 304 (1-3):305-313. http:/ / dx.doi.org/ 10.1016/ S00489697(02)00577-6

Balogh, S. J., E. B. Swain, and Y. H. Nollet. 2008. Characteristics of mercury speciation in Minnesota rivers and streams. Environmental Pollution 154 (1):3-11. http:/ / dx.doi.org/ 10.1016/j.envpol.2007.11.014

Bookman, R., C. T. Driscoll, D. R. Engstrom, and S. W. Effler. 2008. Local to regional emission sources affecting mercury fluxes to New York lakes. Atmospheric Environment 42 (24):6088-6097. http://dx.doi.org/ 10.1016/j.atmosenv.2008.03.045

Brown, M. E., M. Kowalewski, R. J . Neves, D. S. Cherry, and M. E. Schreiber. 2005. Freshwater mussel shells as environmental chronicles: Geochemical and taphonomic signatures of mercury-related extirpations in the North Fork Holston River, Virginia. Environmental Science and Technology 39 (6):1455-1462. http:// dx.doi.org/ 10.1021/ es048573p

Brown, S., L. Saito, C. Knightes, and M. Gustin. 2007. Calibration and evaluation of a mercury model for a western stream and constructed wetland. Water, Air, and Soil Pollution 182 (1-4):275-290. http:/ / dx.doi.org/ 10.1007/s11270-007-9338-8

Buck, N. J ., C. J . Gobler, and S. A. Sanudo-Wilhelmy. 2005. Dissolved trace element concentrations in the East River - Long Island Sound system: Relative importance of autochthonous versus allochthonous sources. Environmental Science and Technology 39 (10):3528-3537. http:// dx.doi.org/ 10.1021/ es048860t

Casey, R. E., A. N. Shaw, L. R. Massal, and J. W. Snodgrass. 2005. Multimedia evaluation of trace metal distribution within stormwater retention ponds in suburban Maryland, USA. Bulletin of Environmental Contamination and Toxicology 74 (2):273-280. http:// dx.doi.org/ 10.1007/ s00128-004-0580-0

Chavan, P. V., K. E. Dennett, E. A. Marchand, and M. S. Gustin. 2007. Evaluation of small-scale constructed wetland for water quality and $\mathrm{Hg}$ transformation. J ournal of Hazardous Materials 149 (3):543-547. http:// dx.doi.org/ 10.1016/j.jhazmat.2007.06.077

Chen, C. W., J. W. Herr, and R. A. Goldstein. 2008. Model calculations of total maximum daily loads of mercury for drainage lakes. J ournal of the American Water Resources Association 44 (5): 1295-1307. http:// dx.doi.org/ 10.1111/j.17521688.2008.00224.x 
DeLaune, R. D., A. J ugsujinda, I. Devai, and W. H. PatrickJ r. 2004. Relationship of sediment redox conditions to methyl mercury in surface sediment of Louisiana Lakes. J ournal of Environmental Science and Health - Part A Toxic/ Hazardous Substances and Environmental Engineering 39 (8):1925-1933.

Evers, D. C., Y. J. Han, C. T. Driscoll, N. C. Kamman, M. W. Goodale, K. F. Lambert, T. M. Holsen, C. Y. Chen, T. A. Clair, and T. Butler. 2007. Biological mercury hotspots in the northeastern United States and southeastern Canada. Bioscience 57 (1):2943.

Fitzgibbon, T. O., W. Berry Lyons, C. B. Gardner, and A. E. Carey. 2008. A preliminary study of the Hg flux from selected Ohio watersheds to Lake Erie. Applied Geochemistry 23 (12):3434-3441. http:/ / dx.doi.org/ 10.1016/j.apgeochem.2008.07.013

Gorski, P. R., D. E. Armstrong, J . P. Hurley, and D. P. Krabbenhoft. 2008. Influence of natural dissolved organic carbon on the bioavailability of mercury to a freshwater alga. Environmental Pollution 154 (1):116-123. http:// dx.doi.org/ 10.1016/j.envpol.2007.12.004

Gorski, P. R., D. E. Armstrong, J . P. Hurley, and M. M. Shafer. 2006. Speciation of aqueous methylmercury influences uptake by a freshwater alga (Selenastrum capricornutum). Environmental Toxicology and Chemistry 25 (2):534-540. http:/ / dx.doi.org/ 10.1897/ 04-530R.1

Guentzel, J . L. 2009. Wetland influences on mercury transport and bioaccumulation in South Carolina. Science of the Total Environment 407 (4):1344-1353. http:// dx.doi.org/ 10.1016/j.scitotenv.2008.09.030

Gustin, M. S., P. V. Chavan, K. E. Dennett, S. Donaldson, E. Marchand, and G. Fernanadez. 2006. Use of constructed wetlands with four different experimental designs to assess the potential for methyl and total $\mathrm{Hg}$ outputs. Applied Geochemistry 21(11):2023-2035. http:// dx.doi.org/ 10.1016/j.apgeochem.2006.08.012

Gustin, M. S., P. V. Chavan, K. E. Dennett, E. A. Marchand, and S. Donaldson. 2006. Evaluation of wetland methyl mercury export as a function of experimental manipulations. J ournal of Environmental Quality 35 (6):2352-2359. http:// dx.doi.org/ 10.2134/ jeq2005.0478

Hall, B. D., G. R. Aiken, D. P. Krabbenhoft, M. Marvin-DiPasquale, and C. M. Swarzenski. 2008. Wetlands as principal zones of methylmercury production in southern Louisiana and the Gulf of Mexico region. Environmental Pollution 154 (1):124134. http:// dx.doi.org/ 10.1016/j.envpol.2007.12.017

Hines, N. A., P. L. Brezonik, and D. R. Engstrom. 2004. Sediment and porewater profiles and fluxes of mercury and methylmercury in a small seepage lake in northern Minnesota. Environmental Science and Technology 38 (24):6610-6617. http:// dx.doi.org/ 10.1021/ es0496672

Holloway, J . M., M. B. Goldhaber, and J . M. Morrison. 2009. Geomorphic controls on mercury accumulation in soils from a historically mined watershed, Central California Coast Range, USA. Applied Geochemistry 24 (8):1538-1548. http:// dx.doi.org/ 10.1016/j.apgeochem.2009.04.020 
Hope, B. K. 2005. A mass budget for mercury in the Willamette River Basin, Oregon, USA. Water, Air, and Soil Pollution 161 (1-4):365-382. http:// dx.doi.org/ 10.1007/ s11270-005-5549-z

Hutcheson, M. S., C. M. Smith, G. T. Wallace, J . Rose, B. Eddy, J . Sullivan, O. Pancorbo, and C. R. West. 2008. Freshwater fish mercury concentrations in a regionally high mercury deposition area. Water, Air, and Soil Pollution 191 (1-4):15-31. http:/ / dx.doi.org/ 10.1007/ s11270-007-9604-9

J ohnson, B. E., B. K. Esser, D. C. Whyte, P. M. Ganguli, C. M. Austin, and J . R. Hunt. 2009. Mercury accumulation and attenuation at a rapidly forming delta with a point source of mining waste. Science of the Total Environment 407 (18):50565070. http:// dx.doi.org/ 10.1016/j.scitotenv.2009.05.025

Kamman, N. C., P. M. Lorey, C. T. Driscoll, R. Estabrook, A. Major, B. Pientka, and E. Glassford. 2004. Assessment of mercury in waters, sediments, and biota of New Hampshire and Vermont lakes, USA, sampled using a geographically randomized design. Environmental Toxicology and Chemistry 23 (5):1172-1186. http:// dx.doi.org/ 10.1897/ 03-170

Knox, A. S., M. H. Paller, E. A. Nelson, W. L. Specht, N. V. Halverson, and J . B. Gladden. 2006. Metal distribution and stability in constructed wetland sediment. J ournal of Environmental Quality 35 (5):1948-1959. http:// dx.doi.org/ 10.2134/ jeq2006.0017

Lind, O. T., L. Davalos-Lind, and T. E. Ford. 2000. Clay and the movement of metals into food fishes. J ournal of Environmental Science and Health - Part A Toxic/ Hazardous Substances and Environmental Engineering 35 (7):1171-1182.

Lyons, W. B., T. O. Fitzgibbon, K. A. Welch, and A. E. Carey. 2006. Mercury geochemistry of the Scioto River, Ohio: Impact of agriculture and urbanization. Applied Geochemistry 21(11):1880-1888. http:// dx.doi.org/ 10.1016/j.apgeochem.2006.08.005

Mackie, J . A., S. M. Natali, J. S. Levinton, and S. A. Sanudo-Wilhelmy. 2007. Declining metal levels at Foundry Cove (Hudson River, New York): Response to localized dredging of contaminated sediments. Environmental Pollution 149 (2):141-148. http:/ / dx.doi.org/ 10.1016/j.envpol.2007.01.010

Mahler, B. J., P. C. Van Metre, and E. Callender. 2006. Trends in metals in urban and reference lake sediments across the United States, 1970 to 2001. Environmental Toxicology and Chemistry 25 (7):1698-1709. http:/ / dx.doi.org/ 10.1897/ 05459R.1

Mailman, M., L. Stepnuk, N. Cicek, and R. A. Bodaly. 2006. Strategies to lower methyl mercury concentrations in hydroelectric reservoirs and lakes: A review. Science of the Total Environment 368 (1):224-235.

http:// www.sciencedirect.com/science?_ob=MImg\&_imagekey=B6V78-

4HTCTD0-2-

$1 \&$ _cdi $=5836 \&$ _ user $=930810 \&$ _ orig $=$ search\&_coverDate $=09 \% 2 \mathrm{~F} 01 \% 2 \mathrm{~F} 2006 \&$ sk $=996319998 \& v i e w=c \& w c h p=d G L b V z z-$

zSkzk\&md5=d1ef732bfacf695252c798a358a4c383\&ie=/ sdarticle.pdf 
Marcantonio, F., G. C. Flowers, and N. Templin. 2000. Lead contamination in a wetland watershed: Isotopes as fingerprints of pollution. Environmental Geology 39 (9):1070-1076.

Miao, S., R. D. DeLaune, and A. Jugsujinda. 2006. Influence of sediment redox conditions on release/ solubility of metals and nutrients in a Louisiana Mississippi River deltaic plain freshwater lake. Science of the Total Environment 371 (1-3):334-343. http:/ / dx.doi.org/ 10.1016/j.scitotenv.2006.07.027

Nimick, D. A., B. R. McCleskey, C. H. Gammons, T. E. Cleasby, and S. R. Parker. 2007. Diel mercury-concentration variations in streams affected by mining and geothermal discharge. Science of the Total Environment 373 (1):344-355. http:// dx.doi.org/ 10.1016/j.scitotenv.2006.11.008

Paller, M. H., and J. W. Littrell. 2007. Long-term changes in mercury concentrations in fish from the middle Savannah River. Science of the Total Environment 382 (2-3):375-382. http: // dx.doi.org/ 10.1016/j.scitotenv.2007.04.018

Paller, M. H., C. H. J agoe, H. Bennett, H. A. Brant, and J . A. Bowers. 2004. Influence of methylmercury from tributary streams on mercury levels in Savannah River Asiatic clams. Science of the Total Environment 325 (1-3):209-219. http:// dx.doi.org/ 10.1016/j.scitotenv.2003.11.008

Peterson, C., and M. Gustin. 2008. Mercury in the air, water and biota at the Great Salt Lake (Utah, USA). Science of the Total Environment 405 (1-3):255-268. http:/ / dx.doi.org/ 10.1016/j.scitotenv.2008.06.046

Pickhardt, P. C., C. L. Folt, C. Y. Chen, B. Klaue, and J. D. Blum. 2005. Impacts of zooplankton composition and algal enrichment on the accumulation of mercury in an experimental freshwater food web. Science of the Total Environment 339 (1-3):89-101. http:/ / dx.doi.org/ 10.1016/j.scitotenv.2004.07.025

Regnell, O., C. J . Watras, B. Troedsson, A. Helgee, and T. Hammar. 2009. Mercury in a boreal forest stream - Role of historical mercury pollution, TOC, temperature, and water discharge. Environmental Science and Technology 43 (10):3514-3521. http:/ / dx.doi.org/ 10.1021/ es802991x

Rumbold, D. G., and L. E. Fink. 2006. Extreme spatial variability and unprecedented methylmercury concentrations within a constructed wetland. Environmental Monitoring and Assessment 112 (1-3):115-135. http:// dx.doi.org/ 10.1007/ s10661-006-0767-4

Sheehan, K. D., I. J . Fernandez, J . S. Kahl, and A. Amirbahman. 2006. Litterfall mercury in two forested watersheds at Acadia National Park, Maine, USA. Water, Air, and Soil Pollution 170 (1-4):249-265. http:/ / dx.doi.org/ 10.1007/s11270-006-3034-y

Southworth, G. R., R. R. Turner, M. J . Peterson, M. A. Bogle, and M. G. Ryon. 2000. Response of mercury contamination in fish to decreased aqueous concentrations and loading of inorganic mercury in a small stream. Environmental Monitoring and Assessment 63 (3):481-494. http:/ / dx.doi.org/ 10.1023/ A: 1006237610383 
Suchanek, T. H., J. Cooke, K. Keller, S. J orgensen, P. J. Richerson, C. A. Eagles-Smith, E. J. Harner, and D. P. Adam. 2009. A Mass balance mercury budget for a minedominated lake: Clear Lake, California. Water, Air, and Soil Pollution 196 (1-4):51-73. http:// dx.doi.org/ 10.1007/ s11270-008-9757-1

Suchanek, T. H., P. J . Richerson, J . R. Flanders, D. C. Nelson, L. H. Mullen, L. L. Brister, and J . C. Becker. 2000. Monitoring inter-annual variability reveals sources of mercury contamination in Clear Lake, California. Environmental Monitoring and Assessment 64 (1):299-310. http:// dx.doi.org/ 10.1023/ A: 1006414332331

Sutherland, R. A. 2000. Bed sediment-associated trace metals in an urban stream, Oahu, Hawaii. Environmental Geology 39 (6):611-627.

Tsui, M. T. K., J . C. Finlay, and E. A. Nater. 2008. Effects of stream water chemistry and tree species on release and methylation of mercury during litter decomposition. Environmental Science and Technology 42 (23):8692-8697. http:/ / dx.doi.org/ 10.1021/ es800956q

Warner, K. A., J .-C. J . Bonzongo, E. E. Roden, G. M. Ward, A. C. Green, I. Chaubey, W. B. Lyons, and D. A. Arrington. 2005. Effect of watershed parameters on mercury distribution in different environmental compartments in the Mobile Alabama River Basin, USA. Science of the Total Environment 347 (1-3):187-207. http:/ / dx.doi.org/ 10.1016/j.scitotenv.2004.12.011

Watras, C. J., K. A. Morrison, A. Kent, N. Price, O. Regnell, C. Eckley, H. Hintelmann, and T. Hubacher. 2005. Sources of methylmercury to a wetland-dominated lake in northern Wisconsin. Environmental Science and Technology 39 (13):4747-4758. http:/ / dx.doi.org/ 10.1021/ es040561g

Weis, J. S., and P. Weis. 2004. Metal uptake, transport and release by wetland plants: Implications for phytoremediation and restoration. Environment International 30 (5):685-700. http:// dx.doi.org/ 10.1016/j.envint.2003.11.002

Yu, K., R. D. Delaune, I. Devai, R. Tao, and A. J ugsujinda. 2008. Total and methyl mercury in wetland soils and sediments of Louisiana's Pontchartrain Basin (USA). J ournal of Environmental Science and Health - Part A Toxic/ Hazardous Substances and Environmental Engineering 43 (14):1657-1662.

http:// dx.doi.org/ 10.1080/ 10934520802330008 


\section{Appendix H: Hydrology}

Ahn, C., D. M. J ohnston, R. E. Sparks, and D. C. White. 2006. Analysis of naturalization alternatives for the recovery of moist-soil plants in the floodplain of the Illinois River. Hydrobiologia 565 (1 SPEC. ISS.):217-228. http:// dx.doi.org/ 10.1007/s10750-005-1915-5

Allred, B. J., L. C. Brown, N. R. Fausey, R. L. Cooper, W. B. Clevenger, G. L. Prill, G. A. LaBarge, C. Thornton, D. T. Riethman, P. W. Chester, and B. J . Czartoski. 2003. Water table management to enhance crop yields in a wetland reservoir subirrigation system. Applied Engineering in Agriculture 19 (4):407-421.

Anderson, M. L., Z. Q. Chen, and M. L. Kavvas. 2004. Modeling low flows on the Cosumnes River. J ournal of Hydrologic Engineering 9 (2):126-134. http:/ / dx.doi.org/ 10.1061/ (ASCE)1084-0699(2004)9:2(126)

Barry, F., D. Ophori, J . Hoffman, and R. Canace. 2009. Groundwater flow and capture zone analysis of the Central Passaic River Basin, New J ersey. Environmental Geology 56 (8):1593-1603. http:// dx.doi.org/ 10.1007/ s00254-008-1257-5

Boutt, D. F., and B. J . Fleming. 2009. Implications of anthropogenic river stage fluctuations on mass transport in a valley fill aquifer. Water Resources Research 45 (4). http:/ / dx.doi.org/ 10.1029/2007WR006526

Bredehoeft, J ., and E. Kendy. 2008. Strategies for offsetting seasonal impacts of pumping on a nearby stream. Ground Water 46 (1):23-29. http:// dx.doi.org/ 10.1111/j.1745-6584.2007.00367.x

Brody, S. D., W. E. Highfield, H. C. Ryu, and L. Spanel-Weber. 2007. Examining the relationship between wetland alteration and watershed flooding in Texas and Florida. Natural Hazards 40 (2):413-428. http:// www.springerlink.com/ content/ 052637724628240u/ fulltext.pdf

Butler, J . J ., J r., X. Zhan, and V. A. Zlotnik. 2007. Pumping-induced drawdown and stream depletion in a leaky aquifer system. Ground Water 45 (2):178-186. http:// dx.doi.org/ 10.1111/j.1745-6584.2006.00272.x

Butler, J. J ., J r., V. A. Zlotnik, and M.-S. Tsou. 2001. Drawdown and stream depletion produced by pumping in the vicinity of a partially penetrating stream. Ground Water 39 (5):651-659.

Covington, J . S., and W. A. Hubert. 2003. Trout population responses to restoration of stream flows. Environmental Management 31 (1):135-146. http:// dx.doi.org/ 10.1007/ s00267-002-2751-2

Doll, B. A., D. E. Wise-Frederick, C. M. Buckner, S. D. Wilkerson, W. A. Harman, R. E. Smith, and J. Spooner. 2002. Hydraulic geometry relationships for urban streams throughout the Piedmont of North Carolina. J ournal of the American Water Resources Association 38 (3):641-651. 
Downer, C. W., and F. L. Ogden. 2004. GSSHA: Model to simulate diverse stream flow producing processes. J ournal of Hydrologic Engineering 9 (3):161-174. http:// dx.doi.org/ 10.1061/(ASCE)1084-0699(2004)9:3(161)

Ford, C. R., and J . R. Brooks. 2002. Detecting forest stress and decline in response to increasing river flow in southwest Florida, USA. Forest Ecology and Management 160 (1-3):45-64. http:// dx.doi.org/ 10.1016/ S0378-1127(01)004406

Franklin, S. B., T. Wasklewicz, J . W. Grubaugh, and S. Greulich. 2003. Hydrologic stage periodicity of the Mississippi River before and after systematic channel modifications. J ournal of the American Water Resources Association 39 (3):637648.

Freeman, M. C., and P. A. Marcinek. 2006. Fish assemblage responses to water withdrawals and water supply reservoirs in piedmont streams. Environmental Management 38 (3):435-450. http:// dx.doi.org/ 10.1007/ s00267-005-0169-3

Genereux, D. P., S. Leahy, H. Mitasova, C. D. Kennedy, and D. R. Corbett. 2008. Spatial and temporal variability of streambed hydraulic conductivity in West Bear Creek, North Carolina, USA. J ournal of Hydrology 358 (3-4):332-353.

http:// dx.doi.org/ 10.1016/j.jhydrol.2008.06.017

Goswami, D., P. K. Kalita, R. A. Cooke, and M. C. Hirschi. 2008. Estimation and analysis of baseflow in drainage channels in two tile-drained watersheds in Illinois. Transactions of the ASABE 51(4):1201-1213.

$\mathrm{Gu}, \mathrm{R}$., and M. Deutschman. 2001. Hydrologic assessment of water losses in river. J ournal of Water Resources Planning and Management 127 (1):6-12. http:/ / dx.doi.org/ 10.1061/ (ASCE)0733-9496(2001)127:1(6)

Hunt, R. J ., M. Strand, and J. F. Walker. 2006. Measuring groundwater-surface water interaction and its effect on wetland stream benthic productivity, Trout Lake watershed, northern Wisconsin, USA. J ournal of Hydrology 320 (3-4):370-384. http:// dx.doi.org/ 10.1016/j.jhydrol.2005.07.029

J ain, S., and J . K. Eischeid. 2008. What a difference a century makes: Understanding the changing hydrologic regime and storage requirements in the Upper Colorado River basin. Geophysical Research Letters 35 (16). http:/ / dx.doi.org/ 10.1029/2008GL034715

J emberie, A. A., N. Pinter, and J . W. F. Remo. 2008. Hydrologic history of the Mississippi and Lower Missouri Rivers based upon a refined specific-gauge approach. Hydrological Processes 22 (22):4436-4447. http:// dx.doi.org/ 10.1002/ hyp.7046

Kazezyelmaz-Alhan, C. M., and M. A. Medina Jr. 2008. The effect of surface/ ground water interactions on wetland sites with different characteristics. Desalination 226 (1-3):298-305. http:/ / dx.doi.org/ 10.1016/j.desal.2007.01.246

Kennen, J . G., L. J . Kauffman, M. A. Ayers, D. M. Wolock, and S. J . Colarullo. 2008. Use of an integrated flow model to estimate ecologically relevant hydrologic characteristics at stream biomonitoring sites. Ecological Modelling 211 (1-2):5776. http:// dx.doi.org/ 10.1016/j.ecolmodel.2007.08.014 
Leathers, D. J ., M. L. Malin, D. B. Kluver, G. R. Henderson, and T. A. Bogart. 2008. Hydroclimatic variability across the Susquehanna River Basin, USA, since the 17th century. International J ournal of Climatology 28 (12):1615-1626. http://dx.doi.org/ 10.1002/joc.1668

Maassel J acobsen, S. M. 2003. Baffled by wetland hydrology? Resource: Engineering and Technology for Sustainable World 10 (3):9-10.

Miller, R. C., and J . B. Zedler. 2003. Responses of native and invasive wetland plants to hydroperiod and water depth. Plant Ecology 167 (1):57-69. http:// dx.doi.org/ 10.1023/ A: 1023918619073

Mitchell, M. J ., P. J . McHale, S. Inamdar, and D. J . Raynal. 2001. Role of within-lake processes and hydrobiogeochemical changes over 16 years in a watershed in the Adirondack Mountains of New York state, USA. Hydrological Processes 15 (10):1951-1965. http:// dx.doi.org/ 10.1002/ hyp.249

Moon, J ., R. Srinivasan, and J. H. J acobs. 2004. Stream flow estimation using spatially distributed rainfall in the Trinity River Basin, Texas. Transactions of the American Society of Agricultural Engineers 47 (5):1445-1451.

Nadim, F., A. C. Bagtzoglou, S. A. Baun, G. S. Warner, F. Ogden, R. A. J acobson, and P. Parasiewicz. 2007. Management of adverse effects of a public water supply well field on the aquatic habitat of a stratified drift stream in eastern Connecticut. Water Environment Research 79 (1):43-56. http:/ / dx.doi.org/ 10.2175/ 106143006X136801

Pant, H. K., and K. R. Reddy. 2001. Hydrologic influence on stability of organic phosphorus in wetland detritus. J ournal of Environmental Quality 30 (2):668674.

Pegg, M. A., and C. L. Pierce. 2002. Fish community structure in the Missouri and lower Yellowstone rivers in relation to flow characteristics. Hydrobiologia 479:155-167. http:// dx.doi.org/ 10.1023/A: 1021038207741

Rivenbark, B. L., and C. R. J ackson. 2004. Average discharge, perennial flow initiation, and channel initiation - Small southern Appalachian basins. J ournal of the American Water Resources Association 40 (3):639-646.

Sjodin, A., W. M. Lewis J r., and J . F. Saunders III. 2001. Analysis of groundwater exchange for a large plains river in Colorado (USA). Hydrological Processes 15 (4):609-620.

Skaggs, R. W., G. M. Chescheir, and B. D. Phillips. 2005. Methods to determine lateral effect of a drainage ditch on wetland hydrology. Transactions of the American Society of Agricultural Engineers 48 (2):577-584.

Smith, S. G. L., and A. M. J. Davis. 2009. Time dependence of groundwater pumping from a well near a river. Proceedings of the Royal Society A: Mathematical, Physical and Engineering Sciences 465 (2101):175-192. http:// dx.doi.org/ 10.1098/ rspa.2008.0204 
Su, G. W., J . J asperse, D. Seymour, J . Constante, and Q. Zhou. 2007. Analysis of pumping-induced unsaturated regions beneath a perennial river. Water Resources Research 43 (8). http: // dx.doi.org/ 10.1029/2006WR005389

Troutman, B. M., and T. M. Over. 2001. River flow mass exponents with fractal channel networks and rainfall. Advances in Water Resources 24 (9-10):967-989. http:/ / dx.doi.org/ 10.1016/ S0309-1708(01)00031-8

Webb, R. H., and S. A. Leake. 2006. Ground-water surface-water interactions and longterm change in riverine riparian vegetation in the southwestern United States. J ournal of Hydrology 320 (3-4):302-323. http://dx.doi.org/ 10.1016/j.jhydrol.2005.07.022

Weiler, K., T. Walter, M. F. Walter, E. S. Brooks, and C. A. Scott. 2000. Seasonal risk analysis for floodplains in the Delaware River Basin. J ournal of Water Resources Planning and Management 126 (5):320-329. http:// dx.doi.org/ 10.1061/(ASCE)0733-9496(2000)126:5(320)

Wemple, B., J . Shanley, J . Denner, D. Ross, and K. Mills. 2007. Hydrology and water quality in two mountain basins of the northeastern US: Assessing baseline conditions and effects of ski area development. Hydrological Processes 21 (12):1639-1650. http:// dx.doi.org/ 10.1002/ hyp.6700

Westbrook, C. J ., D. J . Cooper, and B. W. Baker. 2006. Beaver dams and overbank floods influence groundwater-surface water interactions of a Rocky Mountain riparian area. Water Resources Research 42 (6). http:/ / dx.doi.org/ 10.1029/ 2005WR004560

White, A. B., P. Kumar, P. M. Saco, B. L. Rhoads, and B. C. Yen. 2003. Changes in hydrologic response due to stream network extension via land drainage activities. J ournal of the American Water Resources Association 39 (6):1547-1560.

Wondzell, S. M., J . LaNier, and R. Haggerty. 2009. Evaluation of alternative groundwater flow models for simulating hyporheic exchange in a small mountain stream. J ournal of Hydrology 364 (1-2):142-151. http:// dx.doi.org/ 10.1016/j.jhydrol.2008.10.011

Wu, K., and C. A. J ohnston. 2008. Hydrologic comparison between a forested and a wetland/ lake dominated watershed using SWAT. Hydrological Processes 22 (10):1431-1442. http:// dx.doi.org/ 10.1002/ hyp.6695

Ye, B., D. Yang, and D. L. Kane. 2003. Changes in Lena River streamflow hydrology: Human impacts versus natural variations. Water Resources Research 39 (7):SWC81-SWC814. http:/ / dx.doi.org/ 10.1029/ 2003WR001991 


\section{Appendix I: Impoundments}

Andradottir, H. O., and H. M. Nepf. 2000. Thermal mediation in a natural littoral wetland: Measurements and modeling. Water Resources Research 36 (10):29372946. http:// dx.doi.org/ 10.1029/ 2000WR900201

Arnwine, D. H., K. J . Sparks, and R. R. J ames. 2006. Probabilistic monitoring of streams below small impoundments in Tennessee. Nashville, TN: Tennessee Department of Environment and Conservation. http://www.state.tn.us/ environment/ wpc/ publications/pdf/isp_report.pdf

Ashley, J. T. F., K. Bushaw-Newton, M. Wilhelm, A. Boettner, G. Drames, and D. J . Velinsky. 2006. The effects of small dam removal on the distribution of sedimentary contaminants. Environmental Monitoring and Assessment 114 (1-3):287-312. http:// dx.doi.org/ 10.1007/ s10661-006-4781-3

Auble, G., P. Shafroth, M. Scott, and J . Roelle. 2007. Early vegetation development on an exposed reservoir: Implications for dam removal. Environmental Management 39 (6):806-818. http:// dx.doi.org/ 10.1007/ s00267-006-0018-z

Bailard, J . A. 2001. Sedimental journey. Civil Engineering 71 (3):66-69.

Bartholow, J. M., S. G. Campbell, and M. Flug. 2004. Predicting the thermal effects of dam removal on the Klamath river. Environmental Management 34 (6):856-874. http:// dx.doi.org/ 10.1007/ s00267-004-0269-5

Bednarek, A. T. 2001. Undamming rivers: A review of the ecological impacts of dam removal. Environmental Management 27 (6):803-814. http:// dx.doi.org/ 10.1007/s002670010189

Bennett, S. J ., C. M. Cooper, J . C. Ritchie, J . A. Dunbar, P. M. Allen, L. W. Caldwell, and T. M. McGee. 2002. Assessing sedimentation issues within aging flood control reservoirs in Oklahoma. Journal of the American Water Resources Association 38 (5):1307-1322.

Bosch, N. S. 2008. The influence of impoundments on riverine nutrient transport: An evaluation using the Soil and Water Assessment Tool. J ournal of Hydrology 355 (1-4):131-147. http:// dx.doi.org/ 10.1016/j.jhydrol.2008.03.012

Boutt, D. F., and B. J . Fleming. 2009. Implications of anthropogenic river stage fluctuations on mass transport in a valley fill aquifer. Water Resources Research 45 (4). http:/ / dx.doi.org/ 10.1029/ 2007WR006526

Braatne, J . H., S. B. Rood, L. A. Goater, and C. L. Blair. 2008. Analyzing the impacts of dams on riparian ecosystems: A review of research strategies and their relevance to the Snake River through Hells Canyon. Environmental Management 41 (2):267-281. http:// dx.doi.org/ 10.1007/ s00267-007-9048-4 
Bukaveckas, P. A., and A. S. Crain. 2002. Inter-annual, seasonal and spatial variability in nutrient limitation of phytoplankton production in a river impoundment. Hydrobiologia 481:19-31. http:/ / dx.doi.org/ 10.1023/ A: 1021388315552

Bushaw-Newton, K. L., D. D. Hart, J . E. Pizzuto, J . R. Thomson, J . Egan, J . T. Ashley, T. E. J ohnson, R. J . Horwitz, M. Keeley, J . Lawrence, D. Charles, C. Gatenby, D. A. Kreeger, T. Nightengale, R. L. Thomas, and D. J . Velinsky. 2002. An integrative approach towards understanding ecological responses to dam removal: The Manatawny Creek study. J ournal of the American Water Resources Association 38 (6):1581-1599.

Carron, J . C., and H. Rajaram. 2001. Impact of variable reservoir releases on management of downstream water temperatures. Water Resources Research 37 (6):1733-1743. http:// dx.doi.org/ 10.1029/2000WR900390

Chang, H. H. 2008. Case study of fluvial modeling of river responses to dam removal. J ournal of Hydraulic Engineering 134 (3):295-302. http:// dx.doi.org/ 10.1061/(ASCE)0733-9429(2008)134:3(295)

Chang, H. H., D. Pearson, and S. Tanious. 2002. Lagoon restoration near ephemeral river mouth. J ournal of Waterway, Port, Coastal and Ocean Engineering 128 (2):7987. http:// dx.doi.org/ 10.1061/ (ASCE)0733-950X(2002)128:2(79)

Chin, A., D. L. Harris, T. H. Trice, and J . L. Given. 2002. Adjustment of stream channel capacity following dam closure, Yegua Creek, Texas. J ournal of the American Water Resources Association 38 (6):1521-1531.

Chumchal, A. M., and K. D. Hambright. 2009. Ecological factors regulating mercury contamination of fish from Caddo Lake, Texas, USA. Environmental Toxicology and Chemistry 28 (5):962-972. http:// dx.doi.org/ 10.1897/ 08-197.1

Cochrane, T. A., L. D. Norton, C. Castro-Filho, and J . H. Caviglione. 2004. Development of a river sediment transport monitoring system for large reservoirs. Applied Engineering in Agriculture 20 (6):771-781.

Constantz, J ., and H. Essaid. 2007. Influence of groundwater pumping on streamflow restoration following upstream dam removal. Hydrological Processes 21 (21):2823-2834. http:// dx.doi.org/ 10.1002/ hyp.6520

Cowell, C. M., and R. T. Stoudt. 2002. Dam-induced modifications to upper Allegheny River streamflow patterns and their biodiversity implications. J ournal of the American Water Resources Association 38 (1):187-196.

Cui, Y., G. Parker, C. Braudrick, W. E. Dietrich, and B. Cluer. 2006. Dam Removal Express Assessment Models (DREAM). Part 1: Model development and validation. J ournal of Hydraulic Research 44 (3):291-307. http:// dx.doi.org/ 10.1016/j.jcrysgro.2006.05.071

Day, J . W., J r., A. Yanez Arancibia, W. J . Mitsch, A. L. Lara-Dominguez, J . N. Day, J .-Y. Ko, R. Lane, J . Lindsey, and D. Z. Lomeli. 2003. Using Ecotechnology to address water quality and wetland habitat loss problems in the Mississippi basin: A hierarchical approach. Biotechnology Advances 22 (1-2):135-159. http:// dx.doi.org/ 10.1016/j.biotechadv.2003.08.012 
Doyle, M. W., E. H. Stanley, and J. M. Harbor. 2003. Channel adjustments following two dam removals in Wisconsin. Water Resources Research 39 (1):ESG21-ESG215. http://dx.doi.org/ 10.1029/ 2002WR001714

Duke, J . R., J . D. White, P. M. Allen, and R. S. Muttiah. 2007. Riparian influence on hyporheic-zone formation downstream of a small dam in the Blackland Prairie region of Texas. Hydrological Processes 21 (2):141-150.

http:/ / dx.doi.org/ 10.1002/ hyp.6228

Dworkin, S. I. 2003. The hydrogeochemistry of the Lake Waco drainage basin, Texas. Environmental Geology 45 (1):106-114. http: // dx.doi.org/ 10.1007/ s00254-0030862-6

Elbakidze, L. 2006. Potential economic impacts of changes in water availability on agriculture in the Truckee and Carson River Basins, Nevada, USA. J ournal of the American Water Resources Association 42 (4):841-849. http:// dx.doi.org/ 10.1111/j.1752-1688.2006.tb04498.x

Engle, C. R., and D. Valderrama. 2003. Farm-level costs of settling basins for treatment of effluents from levee-style catfish ponds. Aquacultural Engineering 28 (34):171-199. http:// dx.doi.org/ 10.1016/ S0144-8609(03)00027-X

Evans, J . E., J . M. Huxley, and R. K. Vincent. 2007. Upstream channel changes following dam construction and removal using a GIS/ remote sensing approach. J ournal of the American Water Resources Association 43 (3):683-697. http:// dx.doi.org/ 10.1111/j.1752-1688.2007.00055.x

Evans, J . E., N. S. Levine, S. J . Roberts, J . F. Gottgens, and D. M. Newman. 2002. Assessment using GIS and sediment routing of the proposed removal of Ballville Dam, Sandusky River, Ohio. J ournal of the American Water Resources Association 38 (6):1549-1565.

Freeman, M. C., and P. A. Marcinek. 2006. Fish assemblage responses to water withdrawals and water supply reservoirs in piedmont streams. Environmental Management 38 (3):435-450. http:// dx.doi.org/ 10.1007/ s00267-005-0169-3

Gillenwater, D., T. Granata, and U. Zika. 2006. GIS-based modeling of spawning habitat suitability for walleye in the Sandusky River, Ohio, and implications for dam removal and river restoration. Ecological Engineering 28 (3 SPEC. ISS.):311-323. http:// dx.doi.org/ 10.1016/j.ecoleng.2006.08.003

Granata, T., F. Cheng, and M. Nechvatal. 2008. Discharge and suspended sediment transport during deconstruction of a low-head dam. J ournal of Hydraulic Engineering 134 (5):652-657. http:/ / dx.doi.org/ 10.1061/ (ASCE)07339429(2008)134:5(652)

Gross, E. J ., and G. E. Moglen. 2007. Estimating the hydrological influence of Maryland state dams using GIS and the HEC-1 model. J ournal of Hydrologic Engineering 12 (6):690-693. http:// dx.doi.org/ 10.1061/ (ASCE) 1084-0699(2007)12:6(690)

Grubbs, S. A., and J . M. Taylor. 2004. The influence of flow impoundment and river regulation on the distribution of riverine macroinvertebrates at Mammoth Cave National Park, Kentucky, U.S.A. Hydrobiologia 520 (1-3):19-28. http:// dx.doi.org/ 10.1023/ B:HYDR.0000027722.23374.dc 
Haines, T. A., T. W. May, R. T. Finlayson, and S. E. Mierzykowski. 2003. Factors affecting food chain transfer of mercury in the vicinity of the Nyanza site, Sudbury River, Massachusetts. Environmental Monitoring and Assessment 86 (3):211-232. http: / / dx.doi.org/ 10.1023/ A: 1024017329382

Ham, J ., L. Toran, and J. Cruz. 2006. Effect of upstream ponds on stream temperature. Environmental Geology 50 (1):55-61. http:/ / dx.doi.org/ 10.1007/ s00254-0060186-4

Howard Coker, E. 2000. Conversion of a flood control system to a sustainable system: The energy requirements for pipeline transport of silt. Environmental Science and Technology 34 (17):3730-3736. http:// dx.doi.org/ 10.1021/ es990536o

J ohnson, B. M., L. Saito, M. A. Anderson, P. Weiss, M. Andre, and D. G. Fontane. 2004. Effects of climate and dam operations on reservoir thermal structure. J ournal of Water Resources Planning and Management 130 (2):112-122. http:// dx.doi.org/ 10.1061/ (ASCE)0733-9496(2004)130:2(112)

J ohnson, K. S. 2008. Gypsum-karst problems in constructing dams in the USA. Environmental Geology 53 (5):945-950. http:// dx.doi.org/ 10.1007/ s00254007-0720-z

J ohnston, C. A., S. D. Bridgham, and J . P. Schubauer-Berigan. 2001. Nutrient dynamics in relation to geomorphology of riverine wetlands. Soil Science Society of America J ournal 65 (2):557-577.

J uracek, K. E. 2000. Channel stability downstream from a dam assessed using aerial photographs and stream-gage information. J ournal of the American Water Resources Association 36 (3):633-645.

Kay, P., A. Armstrong, A. McDonald, D. Parsons, J . Best, J . Peakall., A. Walker, M. Foulger, S. Gledhill, and M. Tillotson. 2009. A pilot study of the efficacy of residuum lodges for managing sediment delivery to impoundment reservoirs. Water and Environment J ournal 23 (1):52-62.

Konrad, C. P. 2009. Simulating the recovery of suspended sediment transport and riverbed stability in response to dam removal on the Elwha River, Washington. Ecological Engineering 35 (7):1104-1115. http:// dx.doi.org/ 10.1016/j.ecoleng.2009.03.018

Kovacic, D. A., R. M. Twait, M. P. Wallace, and J . M. Bowling. 2006. Use of created wetlands to improve water quality in the Midwest-Lake Bloomington case study. Ecological Engineering 28 (3 SPEC. ISS.):258-270. http:// dx.doi.org/ 10.1016/j.ecoleng.2006.08.002

Lenhart, C. F. 2003. A preliminary review of NOAA's community-based dam removal and fish passage projects. Coastal Management 31(1):79-98. http:/ / dx.doi.org/ 10.1080/ 08920750390168318

Lindloff, S. D. 2003. Institutionalizing the option of dam removal: The New Hampshire initiative. Water Science and Technology 48 (7):9-16. 
Loaiciga, H. A. 2002. Reservoir design and operation with variable lake hydrology. J ournal of Water Resources Planning and Management 128 (6):399-405. http:// dx.doi.org/ 10.1061/ (ASCE)0733-9496(2002)128: 6(399)

Loomis, J . 2002. Quantifying recreation use values from removing dams and restoring free-flowing rivers: A contingent behavior travel cost demand model for the Lower Snake River. Water Resources Research 38 (6):21-28.

Lowney, C. L. 2000. Stream temperature variation in regulated rivers: Evidence for a spatial pattern in daily minimum and maximum magnitudes. Water Resources Research 36 (10):2947-2955. http:/ / dx.doi.org/ 10.1029/ 2000WR900142

Magilligan, F. J ., K. H. Nislow, and B. E. Graber. 2003. Scale-independent assessment of discharge reduction and riparian disconnectivity following flow regulation by dams. Geology 31 (7):569-572. http:// dx.doi.org/ 10.1130/ 00917613(2003)031<0569:SAODRA>2.0.CO;2

Mathur, D., P. G. Heisey, J . R. Skalski, and D. R. Kenney. 2000. Salmonid smolt survival relative to turbine efficiency and entrainment depth in hydroelectric power generation. J ournal of the American Water Resources Association 36 (4): 737747.

MoGrath, K. J ., and T. Tatham. 2007. Providing safe passage. International Water Power and Dam Construction 59 (1):14-17.

Morton, R. A., J . C. Bernier, and J . A. Barras. 2006. Evidence of regional subsidence and associated interior wetland loss induced by hydrocarbon production, Gulf Coast region, USA. Environmental Geology 50 (2):261-274. http:// dx.doi.org/ 10.1007/ s00254-006-0207-3

Needham, J. T., Watkins, D.W, J r., J . R. Lund, and S. K. Nanda. 2000. Linear programming for flood control in the Iowa and Des Moines Rivers. J ournal of Water Resources Planning and Management 126 (3):118-127. http:/ / dx.doi.org/ 10.1061/ (ASCE)0733-9496(2000)126:3(118)

Nicklow, J. W., and L. W. Mays. 2001. Optimal control of reservoir releases to minimize sedimentation in rivers and reservoirs. J ournal of the American Water Resources Association 37 (1):197-211.

Orlins, J .J ., and J . S. Gulliver. 2000. Dissolved gas supersaturation downstream of a spillway. II: Computational model. J ournal of Hydraulic Research/De Recherches Hydrauliques 38 (2):151-159.

Pearsall, S. H., B. J . McCrodden, and P. A. Townsend. 2005. Adaptive management of flows in the lower Roanoke River, North Carolina, USA. Environmental Management 35 (4):353-367. http:// dx.doi.org/ 10.1007/ s00267-003-0255-3

Pejchar, L., and K. Warner. 2001. A river might run through it again: Criteria for consideration of dam removal and interim lessons from California. Environmental Management 28 (5):561-575. http:// dx.doi.org/ 10.1007/ s002670010244 
Phillips, J . D. 2001. Sedimentation in bottomland hardwoods downstream of an east Texas dam. Environmental Geology 40 (7):860-868. http: // dx.doi.org/ 10.1007/ s002540100246

Phillips, J . D., M. C. Slattery, and Z. A. Musselman. 2005. Channel adjustments of the lower Trinity River, Texas, downstream of Livingston Dam. Earth Surface Processes and Landforms 30 (11):1419-1439. http:// dx.doi.org/ 10.1002/ esp.1203

Pinter, N., A. A. J emberie, J . W. F. Remo, R. A. Heine, and B. S. Ickes. 2008. Flood trends and river engineering on the Mississippi River system. Geophysical Research Letters 35 (23). http: / / dx.doi.org/ 10.1029/2008GL035987

Pizzuto, J ., and M. O'Neal. 2009. Increased mid-twentieth century riverbank erosion rates related to the demise of mill dams, South River, Virginia. Geology 37 (1):1922. http: / / dx.doi.org/ 10.1130/ G25207A.1

Poff, N. L., and D. D. Hart. 2002. How dams vary and why it matters for the emerging science of dam removal. Bioscience 52 (8):659-668.

Pohl, M. M. 2002. Bringing down our dams: Trends in American dam removal rationales. J ournal of the American Water Resources Association 38 (6):1511-1519.

Pollard, A. I., and T. Reed. 2004. Benthic invertebrate assemblage change following dam removal in a Wisconsin stream. Hydrobiologia 513:51-58. http:/ / dx.doi.org/ 10.1023/ B: hydr.0000018164.17234.4f

Rieker, J . D., and J . W. Labadie. 2006. GIS visualization and analysis of river operations impacts on endangered species habit. J ournal of Water Resources Planning and Management 132 (3):153-163. http:// dx.doi.org/ 10.1061/ (ASCE)07339496(2006)132: 3(153)

Riggsbee, J . A., J . P. J ulian, M. W. Doyle, and R. G. Wetzel. 2007. Suspended sediment, dissolved organic carbon, and dissolved nitrogen export during the dam removal process. Water Resources Research 43 (9). http:/ / dx.doi.org/ 10.1029/ 2006WR005318

Robbins, J . L., and L. Y. Lewis. 2008. Demolish it and they will come: Estimating the economic impacts of restoring a recreational fishery. J ournal of the American Water Resources Association 44 (6):1488-1499. http:/ / dx.doi.org/ 10.1111/j.1752-1688.2008.00253.x

Roberts, S. J ., J . F. Gottgens, A. L. Spongberg, J . E. Evans, and N. S. Levine. 2007. Assessing potential removal of low-head dams in urban settings: An example from the Ottawa River, NW Ohio. Environmental Management 39 (1):113-124. http:/ / dx.doi.org/ 10.1007/ s00267-005-0091-8

Sawyer, A. H., M. B. Cardenas, A. Bomar, and M. Mackey. 2009. Impact of dam operations on hyporheic exchange in the riparian zone of a regulated river. Hydrological Processes 23 (15):2129-2137. http:/ / dx.doi.org/ 10.1002/ hyp.7324

Schmidt, J . C., and P. R. Wilcock. 2008. Metrics for assessing the downstream effects of dams. Water Resources Research 44 (4).

http:// dx.doi.org/ 10.1029/ 2006WR005092 
Schoch, A. L., K. E. Schilling, and K.-S. Chan. 2009. Time-series modeling of reservoir effects on river nitrate concentrations. Advances in Water Resources 32 (8):11971205. http:// dx.doi.org/ 10.1016/j.advwatres.2009.04.002

Scott, J . T., J . K. Stanley, R. D. Doyle, M. G. Forbes, and B. W. Brooks. 2009. Riverreservoir transition zones are nitrogen fixation hot spots regardless of ecosystem trophic state. Hydrobiologia 625 (1):61-68. http:// dx.doi.org/ 10.1007/ s10750008-9696-2

Sennatt, K. M., N. L. Salant, C. E. Renshaw, and F. J . Magilligan. 2006. Assessment of methods for measuring embeddedness: Application to sedimentation in flow regulated streams. J ournal of the American Water Resources Association 42 (6):1671-1682. http:// dx.doi.org/ 10.1111/j.1752-1688.2006.tb06028.x

Shields, F. D., J r., S. S. Knight, N. Morin, and J . Blank. 2003. Response of fishes and aquatic habitats to sand-bed stream restoration using large woody debris. Hydrobiologia 494:251-257. http:// dx.doi.org/ 10.1023/ A: 1025434920429

Simon, A., R. E. Thomas, A. Curini, and F. D. Shields Jr. 2002. Case study: Channel stability of the Missouri River, eastern Montana. J ournal of Hydraulic Engineering 128 (10):880-890. http:// dx.doi.org/ 10.1061/ (ASCE)07339429(2002)128: 10(880)

Skalak, K., J . Pizzuto, and D. D. Hart. 2009. Influence of small dams on downstream channel characteristics in Pennsylvania and Maryland: Implications for the longterm geomorphic effects of dam removal. J ournal of the American Water Resources Association 45 (1):97-109. http:/ / dx.doi.org/ 10.1111/j.17521688.2008.00263.x

Snyder, N. P., D. M. Rubin, C. N. Alpers, J . R. Childs, J . A. Curtis, L. E. Flint, and S. A. Wright. 2004. Estimating accumulation rates and physical properties of sediment behind a dam: Englebright Lake, Yuba River, northern California. Water Resources Research 40 (11):W1130101-W1130119. http:/ / dx.doi.org/ 10.1029/ 2004WR003279

Sternberg, R. 2006. Damming the river: A changing perspective on altering nature. Renewable and Sustainable Energy Reviews 10 (3):165-197. http:// dx.doi.org/ 10.1016/j.rser.2004.07.004

Svendsen, K. M., C. E. Renshaw, F. J . Magilligan, K. H. Nislow, and J . M. Kaste. 2009. Flow and sediment regimes at tributary junctions on a regulated river: Impact on sediment residence time and benthic macroinvertebrate communities. Hydrological Processes 23 (2):284-296. http:// dx.doi.org/ 10.1002/ hyp.7144

Teeter, A. M., B. H. J ohnson, C. Berger, G. Stelling, N. W. Scheffner, M. H. Garcia, and T. M. Parchure. 2001. Hydrodynamic and sediment transport modeling with emphasis on shallow-water, vegetated areas (lakes, reservoirs, estuaries and lagoons). Hydrobiologia 444:1-23. http:/ / dx.doi.org/ 10.1023/ A: 1017524430610

Tomsic, C. A., T. C. Granata, R. P. Murphy, and C. J . Livchak. 2007. Using a coupled ecohydrodynamic model to predict habitat for target species following dam removal. Ecological Engineering 30 (3):215-230.

http:// dx.doi.org/ 10.1016/j.ecoleng.2006.11.006 
Uowolo, A. L., D. Binkley, and E. C. Adair. 2005. Plant diversity in riparian forests in northwest Colorado: Effects of time and river regulation. Forest Ecology and Management 218 (1-3):107-114. http:// dx.doi.org/ 10.1016/j.foreco.2005.07.003

Van Metre, P. C., and B. J . Mahler. 2004. Contaminant trends in reservoir sediment cores as records of influent stream quality. Environmental Science and Technology 38 (11):2978-2986. http:// dx.doi.org/ 10.1021/ es049859x

Warnken, K. W., and P. H. Santschi. 2004. Biogeochemical behavior of organic carbon in the Trinity River downstream of a large reservoir lake in Texas, USA. Science of the Total Environment 329 (1-3):131-144. http:// dx.doi.org/ 10.1016/j.scitotenv.2004.02.017

Wells, R. R., E. J . Langendoen, and A. Simon. 2007. Modeling pre- and post-dam removal sediment dynamics: The Kalamazoo River, Michigan. J ournal of the American Water Resources Association 43 (3):773-785. http:/ / dx.doi.org/ 10.1111/j.1752-1688.2007.00062.x

White, K. D., and J. N. Moore. 2002. Impacts of dam removal on riverine ice regime. J ournal of Cold Regions Engineering 16 (1):2-16. http:// dx.doi.org/ 10.1061/ (ASCE)0887-381X(2002)16:1(2)

Whittier, T. R., D. P. Larsen, S. A. Peterson, and T. M. Kincaid. 2002. A comparison of impoundments and natural drainage lakes in the Northeast USA. Hydrobiologia 470:157-171. http:/ / dx.doi.org/ 10.1023/ A: 1015688407915

Zabel, R. W., J. Faulkner, S. G. Smith, J . J . Anderson, C. Van Holmes, N. Beer, S. Iltis, J . Krinke, G. Fredricks, B. Bellerud, J . Sweet, and A. Giorgi. 2008. Comprehensive passage (COMPASS) model: A model of downstream migration and survival of juvenile salmonids through a hydropower system. Hydrobiologia 609 (1):289300. http:// dx.doi.org/ 10.1007/ s10750-008-9407-z

Zhang, H., and C. Dill. 2008. Apparent rates of production and loss of dissolved gaseous mercury (DGM) in a southern reservoir lake (Tennessee, USA). Science of the Total Environment 392 (2-3):233-241. http:/ / dx.doi.org/ 10.1016/j.scitotenv.2007.12.005 


\section{Appendix J: Invasive Species}

Abella, S. R., J . E. Spencer, J . Hoines, and C. Nazarchyk. 2009. Assessing an exotic plant surveying program in the Mojave Desert, Clark County, Nevada, USA. Environmental Monitoring and Assessment 151 (1-4):221-230. http://dx.doi.org/ 10.1007/s10661-008-0263-0

Agius, B. P. 2007. Spatial and temporal effects of pre-seeding plates with invasive ascidians: Growth, recruitment and community composition. J ournal of Experimental Marine Biology and Ecology 342 (1):30-39. http://www.sciencedirect.com/science?_ob=MImg\&_imagekey=B6T8F4M6937V-5-

K\&_ cdi $=5085 \&$ user $=930810 \&$ orig $=$ search\&_ coverDate $=03 \% 2 \mathrm{~F} 26 \% 2 \mathrm{~F} 2007$ \& sk $=996579998 \& v i e w=c \& w c h p=d G L b V t z-$ zSkWb\&md5=2f037c285c2ca89be72524c1d1fe3ec7\&ie=/ sdarticle.pdf

Catling, P. M., and S. Carbyn. 2006. Recent invasion, current status and invasion pathway of European Common Reed, Phragmites australis subspecies australis, in the southern Ottawa district. Canadian Field-Naturalist 120 (3):307-312.

Drake, S. J ., J . F. Weltzin, and P. D. Parr. 2003. Assessment of non-native invasive plant species on the United States Department of Energy Oak Ridge National Environmental Research Park. Castanea 68 (1):15-30. http:// www.jstor.org/ stable/ 4034154

Ervin, G., M. Smothers, C. Holly, C. Anderson, and J . Linville. 2006. Relative importance of wetland type versus anthropogenic activities in determining site invasibility. Biological Invasions 8 (6):1425-1432. http:/ / www.springerlink.com/ content/ qr4844177u310612/ fulltext.pdf

Forys, E. A., C. R. Allen, and D. P. Wojcik. 2002. Influence of the proximity and amount of human development and roads on the occurrence of the red imported fire ant in the lower Florida Keys. Biological Conservation 108 (1):27-33. http:// www.sciencedirect.com/science?_ob=MImg\&_imagekey=B6V5X45BCPDD-3-

$4 \&$ cdi $=5798 \&$ user $=930810 \&$ orig $=$ search\&_coverDate $=11 \% 2 F 30 \% 2 F 2002 \&$ sk $=998919998 \& v i e w=c \& w c h p=d G L z V t b-$ zSkzV\&md5=17d341129e2fbb49ca837c71f5c62d6d\&ie=/ sdarticle.pdf

Herrick, B. M., and A. T. Wolf. 2005. Invasive plant species in diked vs. undiked great lakes wetlands. J ournal of Great Lakes Research 31(3):277-287.

Hogan, D. M., and M. R. Walbridge. 2009. Recent land cover history and nutrient retention in riparian wetlands. Environmental Management 44 (1):62-72. http:/ / dx.doi.org/ 10.1007/ s00267-009-9313-9

J odoin, Y., C. Lavoie, P. Villeneuve, M. Theriault, J . Beaulieu, and F. Belzile. 2008. Highways as corridors and habitats for the invasive common reed Phragmites australis in Quebec, Canada. J ournal of Applied Ecology 45 (2):459-466. 
Jones, J . C., D. H. Arner, J . Byrd, L. Yager, and S. Gallagher. 2008. Selected non-native plants of rights-of-ways (ROWs) in the southeastern United States and associated impacts. In Environment Concerns in Rights-of-Way Management 8th International Symposium, ed. W. G.-M. J ohn, P. A. Lawrence, L. B. J ennifer, and M. T. Susan. Amsterdam: Elsevier. http:/ / www.sciencedirect.com/ science/ article/ B8KNJ -4SN8M5K2B/ 2/ 8887efc508d05d93d0cfbd2fe799db31

Larson, D. L., P. J . Anderson, and W. Newton. 2001. Alien plant invasion in mixed-grass prairie: Effects of vegetation type and anthropogenic disturbance. Ecological Applications 11 (1):128-141. http:// www.jstor.org/ stable/ 3061061

Leger, E. A., K. M. Howe, J . Gurevitch, E. Woo, J . Hickman, I. W. Ashton, and M. Lerdau. 2007. The interaction between soil nutrients and leaf loss during early establishment in plant invasion. Forest Science 53 (6):701-709.

Maheu-Giroux, M., and S. de. Blois. 2005. Mapping the invasive species Phragmites australis in linear wetland corridors. Aquatic Botany 83 (4):310-320. http:// www.sciencedirect.com/ science/ article/ B6T4F-4GX0CMJ 2/2/a5c3a55551b4cda658ddbe3b67337a8b

Maheu-Giroux, M., and S. de Blois. 2007. Landscape ecology of Phragmites australis invasion in networks of linear wetlands. Landscape Ecology 22 (2):285-301. http:// www.springerlink.com/ content/ f673845577031407/ fulltext.pdf

Miklovic, S., and S. M. Galatowitsch. 2005. Effect of $\mathrm{NaCl}$ and Typha angustifolia L. on marsh community establishment: A greenhouse study. Wetlands 25 (2):420-429.

Miller, R. C., and J . B. Zedler. 2003. Responses of native and invasive wetland plants to hydroperiod and water depth. Plant Ecology 167 (1):57-69. http:// dx.doi.org/ 10.1023/ A: 1023918619073

Modley, M. D. 2008. Aquatic invasive species rapid response planning partnerships in the Lake Champlain basin: Bridging international, political, social, and economic gaps. Water SA 34 (4 SPEC. ISS.):476-480.

Mortensen, D. A., E. S. J . Rauschert, A. N. Nord, and B. P. Jones. 2009. Forest roads facilitate the spread of invasive plants. Invasive Plant Science and Management 2 (3):191-199. http:// dx.doi.org/ 10.1614\%2FIPSM-08-125.1

Parendes, L. A., and J . A. J ones. 2000. Role of light availability and dispersal in exotic plant invasion along roads and streams in the H.J . Andrews Experimental Forest, Oregon. Conservation Biology 14 (1):64-75. http:/ / www.jstor.org/ stable/ 2641905

Richburg, J . A., W. A. Patterson III, and F. Lowenstein. 2001. Effects of road salt and Phragmites australis invasion on the vegetation of a western Massachusetts calcareous lake-basin fen. Wetlands 21 (2):247-255. http:/ / dx.doi.org/ 10.1672/ 0277-5212(2001)021[0247:EORSAP]2.0.CO;2

Shuster, W. D., C. P. Herms, M. N. Frey, D. J . Doohan, and J . Cardina. 2005. Comparison of survey methods for an invasive plant at the subwatershed level. Biological Invasions 7 (3):393-403. http:// dx.doi.org/ 10.1007/ s10530-004-3904-4 
Silliman, B. R., and M. D. Bertness. 2004. Shoreline development drives invasion of Phragmites australis and the loss of plant diversity on New England salt marshes. Conservation Biology 18 (5):1424-1434.

Talley, T. S., and L. A. Levin. 2001. Modification of sediments and macrofauna by an invasive marsh plant. Biological Invasions 3 (1):51-68.

http:// dx.doi.org/ 10.1023/ A: 1011453003168

Toft, J ., C. Simenstad, J . Cordell, and L. Grimaldo. 2003. The effects of introduced water hyacinth on habitat structure, invertebrate assemblages, and fish diets. Estuaries and Coasts 26 (3):746-758. http:// dx.doi.org/ 10.1007/ BF02711985

Warren, R., P. Fell, J . Grimsby, E. Buck, G. Rilling, and R. Fertik. 2001. Rates, patterns, and impacts of Phragmites australis expansion and effects of experimental Phragmites control on vegetation, macroinvertebrates, and fish within tidelands of the lower Connecticut River. Estuaries and Coasts 24 (1):90-107. http:/ / dx.doi.org/ 10.2307/ 1352816

Weston, L., J . Barney, and A. DiTommaso. 2005. A review of the biology and ecology of three invasive perennials in New York State: J apanese Knotweed ( Polygonum cuspidatum ), Mugwort ( Artemisia vulgaris ) and Pale Swallow-wort ( Vincetoxicum rossicum ). Plant and Soil 277 (1):53-69. http:// dx.doi.org/ 10.1007/s11104-005-3102-x

Wetzel, R. G. 2005. Invasive plants: the process within wetland ecosystems. In Invasive Plants: Ecological and Agricultural Aspects. http:// dx.doi.org/ 10.1007/ 3-76437380-6 7 


\section{Appendix K: Mining Impacts}

Angelo, R. T., M. S. Cringan, D. L. Chamberlain, A. J . Stahl, S. G. Haslouer, and C. A. Goodrich. 2007. Residual effects of lead and zinc mining on freshwater mussels in the Spring River Basin (Kansas, Missouri, and Oklahoma, USA). Science of the Total Environment 384 (1-3):467-496. http: // dx.doi.org/ 10.1016/j.scitotenv.2007.05.045

Balistrieri, L. S., R. R. Seal Ii, N. M. Piatak, and B. Paul. 2007. Assessing the concentration, speciation, and toxicity of dissolved metals during mixing of acidmine drainage and ambient river water downstream of the Elizabeth Copper Mine, Vermont, USA. Applied Geochemistry 22 (5):930-952. http:// dx.doi.org/ 10.1016/j.apgeochem.2007.02.005

Barringer, J . L., T. P. Wilson, Z. Szabo, J . L. Bonin, J . M. Fischer, and N. P. Smith. 2008. Diurnal variations in, and influences on, concentrations of particulate and dissolved arsenic and metals in the mildly alkaline Wallkill River, NewJ ersey, USA. Environmental Geology 53 (6):1183-1199. http://dx.doi.org/ 10.1007/s00254-007-0708-8

Besser, J . M., W. G. Brumbaugh, T. W. May, and C. J . Schmitt. 2007. Biomonitoring of lead, zinc, and cadmium in streams draining lead-mining and non-mining areas, Southeast Missouri, USA. Environmental Monitoring and Assessment 129 (1-3):227-241. http:// dx.doi.org/ 10.1007/ s10661-006-9356-9

Brown, B. V., H. M. Valett, and M. E. Schreiber. 2007. Arsenic transport in groundwater, surface water, and the hyporheic zone of a mine-influenced stream-aquifer system. Water Resources Research 43 (11). http:// dx.doi.org/ 10.1029/ 2006WR005687

Butler, B. A. 2009. Effect of pH, ionic strength, dissolved organic carbon, time, and particle size on metals release from mine drainage impacted streambed sediments. Water Research 43 (5):1392-1402. http:/ / dx.doi.org/ 10.1016/j.watres.2008.12.009

Butler, B. A., J . F. Ranville, and P. E. Ross. 2008. Observed and modeled seasonal trends in dissolved and particulate $\mathrm{Cu}, \mathrm{Fe}, \mathrm{Mn}$, and $\mathrm{Zn}$ in a mining-impacted stream. Water Research 42 (12):3135-3145. http:/ / dx.doi.org/ 10.1016/j.watres.2008.03.004

Caruso, B. S. 2004. Modeling metals transport and sediment/ water interactions in a mining impacted mountain stream. J ournal of the American Water Resources Association 40 (6):1603-1615.

2005. Simulation of metals total maximum daily loads and remediation in a mining-impacted stream. J ournal of Environmental Engineering 131(5):777789. http:// dx.doi.org/ 10.1061/ (ASCE)0733-9372(2005)131: 5(777) 
Caruso, B. S., and T. J . Cox. 2008. Modeling effects of natural flow restoration on metals fate and transport in a mountain stream impacted by mine waste. J ournal of the American Water Resources Association 44 (3):535-551. http:// dx.doi.org/ 10.1111/j.1752-1688.2008.00180.x

Caruso, B. S., T. J . Cox, R. L. Runkel, M. L. Velleux, K. E. Bencala, D. K. Nordstrom, P. Y. J ulien, B. A. Butler, C. N. Alpers, A. Marion, and K. S. Smith. 2008. Metals fate and transport modelling in streams and watersheds: State of the science and USEPA workshop review. Hydrological Processes 22 (19):4011-4021. http:// dx.doi.org/ 10.1002/ hyp.7114

Cohen, R. R. H. 2006. Use of microbes for cost reduction of metal removal from metals and mining industry waste streams. J ournal of Cleaner Production 14 (12-13 SPEC. ISS.):1146-1157. http:// dx.doi.org/ 10.1016/j.jclepro.2004.10.009

DeNicola, D. M., and M. G. Stapleton. 2002. Impact of acid mine drainage on benthic communities in streams: The relative roles of substratum vs. aqueous effects. Environmental Pollution 119 (3):303-315. http: / / dx.doi.org/ 10.1016/ S02697491(02)00106-9

Dsa, J . V., K. S. J ohnson, D. Lopez, C. Kanuckel, and J . Tumlinson. 2008. Residual toxicity of acid mine drainage-contaminated sediment to stream macroinvertebrates: Relative contribution of acidity vs. metals. Water, Air, and Soil Pollution 194 (1-4):185-197. http: // dx.doi.org/ 10.1007/ s11270-008-9707-y

Eger, P., A. J ohnson, S. Dewar, B. Anderson, and P. Churak. 2004. Thinking outside the box - New ways to close old tailing basins. Mining Engineering 56 (1):45-51.

Eger, P., G. Melchert, and J . Wagner. 2000. Using passive treatment systems for mine closure - A good approach or a risky alternative? Mining Engineering 52 (9):7883.

Furman, O., D. G. Strawn, G. H. Heinz, and B. Williams. 2006. Risk assessment test for lead bioaccessibility to waterfowl in mine-impacted soils. J ournal of Environmental Quality 35 (2):450-458. http:// dx.doi.org/ 10.2134/jeq2005.0316

Grosbois, C. A., A. J . Horowitz, J . J . Smith, and K. A. Elrick. 2001. The effect of mining and related activities on the sediment-trace element geochemistry of Lake Coeur d'Alene, Idaho, USA. Part III. Downstream effects: The Spokane River Basin. Hydrological Processes 15 (5):855-875. http:// dx.doi.org/ 10.1002/ hyp.192

Harper, M. P., and B. L. Peckarsky. 2005. Effects of pulsed and pressed disturbances on the benthic invertebrate community following a coal spill in a small stream in northeastern USA. Hydrobiologia 544 (1):241-247. http:// dx.doi.org/ 10.1007/ s10750-005-0862-5

Hartman, K. J ., M. D. Kaller, J . W. Howell, and J . A. Sweka. 2005. How much do valley fills influence headwater streams? Hydrobiologia 532 (1):91-102. http:// dx.doi.org/ 10.1007/ s10750-004-9019-1 
Hickey, P. J ., P. A. McDaniel, and D. G. Strawn. 2008. Characterization of iron- and manganese-cemented redoximorphic aggregates in wetland soils contaminated with mine wastes. J ournal of Environmental Quality 37 (6):2375-2385. http:// dx.doi.org/ 10.2134/ jeq2007.0488

J ames, L. A. 2004. Decreasing sediment yields in northern California: Vestiges of hydraulic gold-mining and reservoir trapping. IAHS-AISH Publication (288):235-244.

_. 2004. Tailings fans and valley-spur cutoffs created by hydraulic mining. Earth Surface Processes and Landforms 29 (7):869-882. http:/ / dx.doi.org/ 10.1002/ esp.1075

J ohnson, V. G., R. E. Peterson, and K. B. Olsen. 2005. Heavy metal transport and behavior in the lower Columbia River, USA. Environmental Monitoring and Assessment 110 (1-3):271-289. http:// dx.doi.org/ 10.1007/ s10661-005-8067-y

Koryak, M., L. J . Stafford, and R. J . Reilly. 2004. Declining intensity of acid mine drainage in the northern Appalachian bituminous coal fields: Major Allegheny River tributaries. J ournal of the American Water Resources Association 40 (3):677-689.

Lee, G., and G. Faure. 2007. Processes controlling trace-metal transport in surface water contaminated by acid-mine drainage in the Ducktown Mining District, Tennessee. Water, Air, and Soil Pollution 186 (1-4):221-232. http:/ / dx.doi.org/ 10.1007/ s11270-007-9479-9

MacCausland, A., and M. E. McTammany. 2007. The impact of episodic coal mine drainage pollution on benthic macroinvertebrates in streams in the Anthracite region of Pennsylvania. Environmental Pollution 149 (2):216-226. http:/ / dx.doi.org/ 10.1016/j.envpol.2006.12.030

Marcus, W. A., G. A. Meyer, and D. R. Nimmo. 2001. Geomorphic control of persistent mine impacts in a Yellowstone Park stream and implications for the recovery of fluvial systems. Geology 29 (4):355-358. http: / / dx.doi.org/ 10.1130/ 00917613(2001)029<0355: GCOPMI>2.0.CO; 2

McKnight, D. M., B. A. Kimball, and R. L. Runkel. 2001. pH dependence of iron photoreduction in a rocky mountain stream affected by acid mine drainage. Hydrological Processes 15 (10):1979-1992. http:// dx.doi.org/ 10.1002/ hyp.251

Menendez, R., J . L. Clayton, P. E. Zurbuch, S. M. Sherlock, H. W. Rauch, and J . J . Renton. 2000. Sand-sized limestone treatment of streams impacted by acid mine drainage. Water, Air, and Soil Pollution 124 (3-4):411-428.

Merovich, G. T., J r., J . M. Stiles, J . T. Petty, P. F. Ziemkiewicz, and J . B. Fulton. 2007. Water chemistry-based classification of streams and implications for restoring mined Appalachian watersheds. Environmental Toxicology and Chemistry 26 (7):1361-1369. http:/ / dx.doi.org/ 10.1897/ 06-424R.1

Merricks, T. C., D. S. Cherry, C. E. Zipper, R. J . Currie, and T. W. Valenti. 2007. Coalmine hollow fill and settling pond influences on headwater streams in Southern West Virginia, USA. Environmental Monitoring and Assessment 129 (1-3):359378. http:// dx.doi.org/ 10.1007/ s10661-006-9369-4 
Moberly, J . G., T. Borch, R. K. Sani, N. F. Spycher, S. S. Sengor, T. R. Ginn, and B. M. Peyton. 2009. Heavy metal-mineral associations in Coeur d'Alene River sediments: A synchrotron-based analysis. Water, Air, and Soil Pollution 201 (1-4):195-208. http:// dx.doi.org/ 10.1007/ s11270-008-9937-z

Nimick, D. A., B. R. McCleskey, C. H. Gammons, T. E. Cleasby, and S. R. Parker. 2007. Diel mercury-concentration variations in streams affected by mining and geothermal discharge. Science of the Total Environment 373 (1):344-355. http:/ / dx.doi.org/ 10.1016/j.scitotenv.2006.11.008

Parry, W. T., C. B. Forster, D. K. Solomon, and L. P. J ames. 2000. Ownership of minetunnel discharge. Ground Water 38 (4):487-496.

Peckenham, J . M., T. Thornton, and B. Whalen. 2009. Sand and gravel mining: Effects on ground water resources in Hancock county, Maine, USA. Environmental Geology 56 (6):1103-1114. http:/ / dx.doi.org/ 10.1007/ s00254-008-1210-7

Peplow, D., and R. Edmonds. 2005. The effects of mine waste contamination at multiple levels of biological organization. Ecological Engineering 24 (1-2):101-119. http:// dx.doi.org/ 10.1016/j.ecoleng.2004.12.011

Ross, R. M., E. S. Long, and D. S. Dropkin. 2008. Response of macroinvertebrate communities to remediation-simulating conditions in Pennsylvania streams influenced by acid mine drainage. Environmental Monitoring and Assessment 145 (1-3):323-338. http:/ / dx.doi.org/ 10.1007/s10661-007-0042-3

Runkel, R. L., and B. A. Kimball. 2002. Evaluating remedial alternatives for an acid mine drainage stream: Application of a reactive transport model. Environmental Science and Technology 36 (5):1093-1101. http:/ / dx.doi.org/ 10.1021/ es0109794

Schmidt, T. S., D. J . Soucek, and D. S. Cherry. 2002. Integrative assessment of benthic macroinvertebrate community impairment from metal-contaminated waters in tributaries of the upper Powell river, Virginia, USA. Environmental Toxicology and Chemistry 21 (10):2233-2241. http:// dx.doi.org/ 10.1897/ 15515028(2002)021<2233:IAOBMC>2.0.CO;2

Shope, C. L., Y. Xie, and C. H. Gammons. 2006. The influence of hydrous Mn-Zn oxides on diel cycling of $\mathrm{Zn}$ in an alkaline stream draining abandoned mine lands. Applied Geochemistry 21 (3):476-491. http:// dx.doi.org/ 10.1016/j.apgeochem.2005.11.004

Suchanek, T. H., J . Cooke, K. Keller, S. J orgensen, P. J . Richerson, C. A. Eagles-Smith, E. J. Harner, and D. P. Adam. 2009. A mass balance mercury budget for a minedominated lake: Clear Lake, California. Water, Air, and Soil Pollution 196 (1-4):51-73. http:// dx.doi.org/ 10.1007/ s11270-008-9757-1

Sullivan, A. B., and J . I. Drever. 2001. Geochemistry of suspended particles in a mineaffected mountain stream. Applied Geochemistry 16 (15):1663-1676. http:// dx.doi.org/ 10.1016/ S0883-2927(01)00064-6

_. 2001. Spatiotemporal variability in stream chemistry in a high-elevation catchment affected by mine drainage. J ournal of Hydrology 252 (1-4):237-250. http:// dx.doi.org/ 10.1016/S0022-1694(01)00458-9 
Zielinski, R. A., J . K. Otton, and C. A. J ohnson. 2001. Sources of salinity near a coal mine spoil pile, North-Central Colorado. J ournal of Environmental Quality 30 (4):1237-1248. 


\section{Appendix L: Powerlines and Pipelines}

Bonneau, J . 2005. A guide to managing rights-of-ways for wildlife habitat. Silver Spring, MD.

Chasko, G. G., and J . E. Gates. 1982. Avian habitat suitability along a transmission-line corridor in an oak-hickory forest region. Wildlife Monographs (82):3-41. http:// www.jstor.org/ stable/ 3830653

Confer, J . L., and S. M. Pascoe. 2003. Avian communities on utility rights-of-ways and other managed shrublands in the northeastern United States: Early-Successional Forests and Shrubland Habitats in the North Eastern United States :Critical Habitats dependent on Disturbance. Forest Ecology and Management 185 (12):193-205. http: / / www.sciencedirect.com/ science/ article/ B6T6X-4991RRF1/2/f6547f27e000a6a4a28502882229ab51

Council, T. L., D. J . Hovey, and M. L. Cox. 2000. Environmental solutions key successful South Texas line installation. Oil and Gas J ournal 98 (30):70-72.

Doherty, P. F., and T. C. Grubb. 1998. Reproductive success of cavity-nesting birds breeding under high-voltage powerlines. The American Midland Naturalist 140 (1):122-128. http:// dx.doi.org/ 10.1674/ 00030031(1998)140[0122:RSOCNB]2.0.CO;2

Genua, S. M. 2008. Pepco's environmental stewardship on transmission line right-of-way vegetation management. In Environment Concerns in Rights-of-Way Management 8th International Symposium, ed. W. G.-M. J ohn, P. A. Lawrence, L. B. J ennifer and M. T. Susan. Amsterdam: Elsevier. http:// www.sciencedirect.com/ science/ article/ B8KNJ -4SN8M5K37/ 2/ 0382a8d17585c818837c5c0ab7364842

Gleason, N. C. 2008. Impacts of power line rights-of-way on forested stream habitat in western Washington. In Environment Concerns in Rights-of-Way Management 8th International Symposium, ed. W. G.-M. J ohn, P. A. Lawrence, L. B. J ennifer and M. T. Susan. Amsterdam: Elsevier.

http:// www.sciencedirect.com/ science/ article/ B8KNJ -4SN8M5K2R/ 2/ 11360711e0ec6bc234db2f1c466f7345

Haggie, M. R., R. A. J ohnstone, and H. A. Allen Jr. 2008. Tree, shrub, and herb succession and five years of management following the establishment of a new electric transmission right-of-way through a wooded wetland. In Environment Concerns in Rights- of-Way Management 8th International Symposium, ed. W. G.-M. J ohn, P. A. Lawrence, L. B. J ennifer and M. T. Susan. Amsterdam: Elsevier. http:// www.sciencedirect.com/ science/ article/ B8KNJ -4SN8M5K31/2/ 282e82eb1e6e55620948e8d4d9084055 
Hale, A. M. 2008. Critical habitat assessment using HEP modeling in ROW corridors. In Environment Concerns in Rights-of-Way Management 8th International Symposium, ed. W. G.-M. J ohn, P. A. Lawrence, L. B. J ennifer and M. T. Susan. Amsterdam: Elsevier. http: // www.sciencedirect.com/ science/ article/ B8KNJ 4SN8M5K-2C/ 2/ 74065ac4f6f731c9f00fc2dc9c4f8453

J ohnson, W. C., R. K. Schreiber, and R. L. Burgess. 1979. Diversity of small mammals in a powerline right-of-way and adjacent forest in east Tennessee. American Midland Naturalist 101(1):231-235. http:// www.jstor.org/ stable/ 2424918

J ones, J . C., D. H. Arner, J . Byrd, L. Yager, and S. Gallagher. 2008. Selected non-native plants of rights-of-ways (ROWs) in the southeastern United States and associated impacts. In Environment Concerns in Rights-of-Way Management 8th International Symposium, ed. W. G.-M. J ohn, P. A. Lawrence, L. B. J ennifer and M. T. Susan. Amsterdam: Elsevier. http:/ / www.sciencedirect.com/ science/ article/ B8KNJ -4SN8M5K2B/2/8887efc508d05d93d0cfbd2fe799db31

Levesque, L., and M. Dube. 2007. Review of the effects of in-stream pipeline crossing construction on aquatic ecosystems and examination of Canadian methodologies for impact assessment. Environmental Monitoring and Assessment 132 (1):395409. http:// dx.doi.org/ 10.1007/s10661-006-9542-9

Loft, E. R., and J . W. Menke. 1984. Deer use and habitat characteristics of transmissionline corridors in a Douglas-fir forest. The J ournal of Wildlife Management 48 (4):1311-1316. http:// www.jstor.org/ stable/ 3801791

Merriam, R. W. 2003. The abundance, distribution and edge associations of six nonindigenous, harmful plants across North Carolina. J ournal of the Torrey Botanical Society 130 (4):283-291.

Mullens, J . B., and R. S. Bristow. 2003. Overcoming the nation's best landscaped sewer: Recreators' perceptions of the Connecticut River. J ournal of the American Water Resources Association 39 (1):7-15.

Niemi, G. J., and J . M. Hanowski. 1984. Effects of a transmission line on bird populations in the Red Lake Peatland, northern Minnesota. The Auk 101 (3):487-498. http:/ / www.jstor.org/ stable/ 4086601

Partridge, D. J . 2003. Dispelling the adage "you can't get there from here" horizontal direction drilling under the Chicopee River Front Street sewer system improvements Chicopee, Massachusetts. J ournal of New England Water Environment Association 37 (1):53-64.

Peterson, A. M. 1993. Effects of electric transmission rights-of-way on trout in forested headwater streams in New York. North American J ournal of Fisheries Management 13 (3):581-585. http:/ / afsjournals.org/ doi/abs/ 10.1577/ 15488675\%281993\%29013\%3C0581\%3AEOETRO\%3E2.3.CO\%3B2

Pisano, W. C., O. C. O'Riordan, F. J . Ayotte, J . R. Barsanti, and D. L. Carr. 2003. Automated sewer and drainage flushing systems in Cambridge, Massachussetts. J ournal of Hydraulic Engineering 129 (4):260-266. http:// dx.doi.org/ 10.1061/(ASCE)0733-9429(2003)129:4(260) 
Russell, K. N., H. Ikerd, and S. Droege. 2005. The potential conservation value of unmowed powerline strips for native bees. Biological Conservation 124 (1):133148. http:// www.sciencedirect.com/ science/article/ B6V5X-4FGXXFV2/2/ cf0b4454ec6d0e9ffcf7b63c208b3e7e

Schreiber, R. K., and J . H. Graves. 1977. Powerline corridors as possible barriers to the movements of small mammals. American Midland Naturalist 97 (2):504-508. http: // www.jstor.org/ stable/ 2425117

Small, M. F., and M. L. Hunter, Jr. 1989. Response of passerines to abrupt forest-river and forest-powerline edges in Maine. The Wilson Bulletin 101(1):77-83.

http://www.jstor.org/ stable/ 4162689

Smith, M. B., D. A. Aborn, T. J . Gaudin, and J . C. Tucker. 2008. Mammalian predator distribution around a transmission line. Southeastern Naturalist 7 (2):289-300. http:// dx.doi.org/ 10.1656/ 1528-7092(2008)7[289:MPDAAT]2.0.CO;2

Tullis, B. P., D. S. Anderson, and S. C. Robinson. 2008. Entrance loss coefficients and inlet control head-discharge relationships for buried-invert culverts. J ournal of Irrigation and Drainage Engineering 134 (6):831-839.

http:/ / dx.doi.org/ 10.1061/ (ASCE)0733-9437(2008)134: 6(831)

Willyard, C. J ., and S. M. Tikalsky. 2008. Research gaps regarding the ecological effects of fragmentation related to transmission-line rights-of-way. In Environment Concerns in Rights-of-Way Management 8th International Symposium, ed. W. G.-M. J ohn, P. A. Lawrence, L. B. J ennifer and M. T. Susan. Amsterdam: Elsevier. http:/ / www.sciencedirect.com/ science/ article/ B8KNJ -4SN8M5K26/2/ decdafe8dcd91ec57d1c0280105451aa 


\section{Appendix M: Regulation, Policy, Mitigation and Restoration}

Abad, J . D., and M. H. Garcia. 2006. RVR Meander: A toolbox for re-meandering of channelized streams. Computers and Geosciences 32 (1):92-101. http:// dx.doi.org/10.1016/j.cageo.2005.05.006

Ahn, C., and R. M. Peralta. 2009. Soil bacterial community structure and physicochemical properties in mitigation wetlands created in the Piedmont region of Virginia (USA). Ecological Engineering 35 (7):1036-1042.

http:// www.sciencedirect.com/science?_ob=MImg\&_imagekey=B6VFB4W4J R0R-1-

7\&_cdi $=6006 \&$ _ user $=930810 \&$ orig $=$ search\&_coverDate $=07 \% 2 \mathrm{~F} 31 \% 2 \mathrm{~F} 2009$ \& sk=999649992\&view=c\&wchp=dGLzVtzzSkWA\&md5=b29a1ea7bf5332dcfd87b994565910ee\&ie=/ sdarticle.pdf

Anderson, C. J ., and B. C. Cowell. 2004. Mulching effects on the seasonally flooded zone of west-central Florida, USA wetlands. Wetlands 24 (4):811-819.

Anonymous. 2006. Compensatory mitigation allowed to offset degradation of streams. J ournal American Water Works Association 98 (10):44-44.

Ashby, W. C. 2006. Sustainable stripmine reclamation. International J ournal of Mining, Reclamation and Environment 20 (2):87-95. http:// dx.doi.org/ 10.1080/ 13895260600557897

Austen, E., and A. Hanson. 2008. Identifying wetland compensation principles and mechanisms for Atlantic Canada using a Delphi approach. Wetlands 28 (3):640655.

Balcombe, C. K., J . T. Anderson, R. H. Fortney, and W. S. Kordek. 2005. Aquatic macroinvertebrate assemblages in mitigated and natural wetlands. Hydrobiologia 541:175-188. http:/ / www.springerlink.com/ content/j1216567p1124265/ fulltext.pdf

Balcombe, C. K., J . T. Anderson, R. H. Fortney, J . S. Rentch, W. N. Grafton, and W. S. Kordek. 2005. A comparison of plant communities in mitigation and reference wetlands in the mid-appalachians. Wetlands 25 (1):130-142.

Balletto, J . H., M. V. Heimbuch, and H. J . Mahoney. 2005. Delaware Bay salt marsh restoration: Mitigation for a power plant cooling water system in NewJ ersey, USA. Ecological Engineering 25 (3):204-213. http:/ / www.sciencedirect.com/science?_ob=MImg\&_imagekey=B6VFB4GTVYJ T-1-

$1 \&$ _cdi=6006\&_user $=930810 \&$ orig $=$ search\&_coverDate $=09 \% 2 F 20 \% 2 \mathrm{~F} 2005$ \&_sk=999749996\&view=c\&wchp=dGLbVlbzS̄kWz\&md5=aa43dfed96049422bf2ea2653f417b05\&ie=/ sdarticle.pdf 
Bauer, D. M., N. E. Cyr, and S. K. Swallow. 2004. Public preferences for compensatory mitigation of salt marsh losses: A contingent choice of alternatives. Conservation Biology 18 (2):401-411.

BenDor, T. 2009. A dynamic analysis of the wetland mitigation process and its effects on no net loss policy. Landscape and Urban Planning 89 (1-2):17-27. http:// www.sciencedirect.com/science?_ob=ArticleURL\&_udi=B6V914TP1F5R-

$1 \&$ user $=930810 \& \_$rdoc $=1 \&$ fmt $=\& \_$orig $=$search\&_sort=d\&_docanchor $=\& v i e$

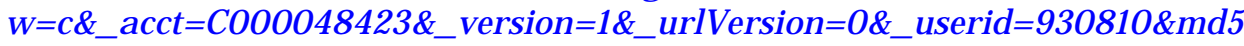

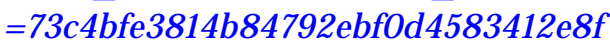

BenDor, T., and N. Brozovic. 2007. Determinants of spatial and temporal patterns in compensatory wetland mitigation. Environmental Management 40 (3):349-364. http:/ / www.springerlink.com/ content/ n085383251276m18/ fulltext.pdf

Braatz, D. A., and R. L. Tucker. 2005. A new series of sediment collectors for developing bed load sediment budgets and restoring streams. IAHS-AISH Publication (291):222-226.

Brenner, F. J . 2001. Use of constructed wetlands for acid mine drainage abatement and stream restoration. Water Science and Technology 44 (11-12):449-454.

Brody, S. D., S. E. Davis, W. E. Highfield, and S. P. Bernhardt. 2008. A spatial-temporal analysis of section 404 wetland permitting in Texas and Florida: Thirteen years of impact along the coast. Wetlands 28 (1):107-116.

Brooks, R. P., D. H. Wardrop, C. A. Cole, and D. A. Campbell. 2005. Are we purveyors of wetland homogeneity? A model of degradation and restoration to improve wetland mitigation performance. Ecological Engineering 24 (4):331-340. http:// www.sciencedirect.com/ science?_ob=MImg\&_imagekey=B6VFB4G4N5RM-1-

7\&_cdi $=6006 \&$ _ user $=930810 \&$ \& orig $=$ search\&_coverDate $=04 \% 2 \mathrm{~F} 05 \% 2 \mathrm{~F} 2005$ \&_sk=999759995\&view=c\&wchp=dGLbVzWzSkWb\&md5=3d4327e83dc10c3f621fefa384c92f50\&ie=/ sdarticle.pdf

Bruland, G. L., and C. J . Richardson. 2005. Spatial variability of soil properties in created, restored, and paired natural wetlands. Soil Science Society of America J ournal 69 (1):273-284. http:/ / soil.scijournals.org/cgi/ reprint/ 69/ 1/ 273.pdf

Carleton, J . N., T. J . Grizzard, A. N. Godrej, H. E. Post, L. Lampe, and P. P. Kenel. 2000. Performance of a constructed wetlands in treating urban stormwater runoff. Water Environment Research 72 (3):295-304.

Chavan, P. V., K. E. Dennett, and E. A. Marchand. 2008. Behavior of pilot-scale constructed wetlands in removing nutrients and sediments under varying environmental conditions. Water, Air, and Soil Pollution 192 (1-4):239-250. http:/ / dx.doi.org/ 10.1007/s11270-008-9651-x

Clausen, J. C., K. Guillard, C. M. Sigmund, and K. Martin Dors. 2000. Water quality changes from riparian buffer restoration in Connecticut. J ournal of Environmental Quality 29 (6):1751-1761. 
Craig, L. S., M. A. Palmer, D. C. Richardson, S. Filoso, E. S. Bernhardt, B. P. Bledsoe, M. W. Doyle, P. M. Groffman, B. A. Hassett, S. S. Kaushal, P. M. Mayer, S. M. Smith, and P. R. Wilcock. 2008. Stream restoration strategies for reducing river nitrogen loads. Frontiers in Ecology and the Environment 6 (10):529-538.

Crifasi, R. 2005. Reflections in a stock pond: Are anthropogenically derived freshwater ecosystems natural, artificial, or something else? Environmental Management 36 (5):625-639. http:// dx.doi.org/ 10.1007/ s00267-004-0147-1

Crispell, J . K., and T. A. Endreny. 2009. Hyporheic exchange flow around constructed inchannel structures and implications for restoration design. Hydrological Processes 23 (8):1158-1168. http:/ / dx.doi.org/ 10.1002/ hyp.7230

Dale, L., and A. K. Gerlak. 2007. It's all in the numbers: Acreage tallies and environmental program evaluation. Environmental Management 39 (2):246260. http:// www.springerlink.com/ content/338glg47618j514q/ fulltext.pdf

D'Angelo, E. M., A. D. Karathanasis, E. J . Sparks, S. A. Ritchey, and S. A. WehrMcChesney. 2005. Soil carbon and microbial communities at mitigated and late successional bottomland forest wetlands. Wetlands 25 (1):162-175.

Davidson, D. W., R. D. Gitar, and D. S. Anderson. 2008. Floristic and ecological studies on the Nelson Mitigation Site, near Grantsburg, Burnett County, Wisconsin. Wulfenia 15:25-34.

Davis, D. E., C. H. Hanson, and R. B. Hansen. 2008. Constructed wetland habitat for American avocet and black-necked stilt foraging and nesting. J ournal of Wildlife Management 72 (1):143-151. http:// dx.doi.org/ 10.2193/ 2005-553

Desrochers, D. W., J . C. Keagy, and D. A. Cristol. 2008. Created versus natural wetlands: Avian communities in Virginia salt marshes. Ecoscience 15 (1):36-43.

DeWalle, D. R. 2008. Guidelines for riparian vegetative shade restoration based upon a theoretical shaded-stream model. J ournal of the American Water Resources Association 44 (6): 1373-1387. http:// dx.doi.org/ 10.1111/j.17521688.2008.00230.x

D'Ignazio, J ., K. McDermott, B. Gilmore, and C. Russo. 2005. North Carolina's Ecosystem Enhancement Program - Mitigation for the future. Energy and Environmental Concerns 2005 (1941):175-183.

Esty, A. 2007. Banking on mitigation. American Scientist 95 (2):122-123.

Fennessy, M. S., A. Rokosch, and J . J . Mack. 2008. Patterns of plant decomposition and nutrient cycling in natural and created wetlands. Wetlands 28 (2):300-310.

Fink, D. F., and W. J . Mitsch. 2007. Hydrology and nutrient biogeochemistry in a created river diversion oxbow wetland. Ecological Engineering 30 (2 SPEC. ISS.):93-102. http:// dx.doi.org/ 10.1016/j.ecoleng.2006.08.008

Forshay, K. J ., H. N. Morzaria-Luna, B. Hale, and K. Predick. 2005. Landowner satisfaction with the wetlands reserve program in Wisconsin. Environmental Management 36 (2):248-257. http:/ / dx.doi.org/ 10.1007/ s00267-004-0093-y 
Gao, S., K. K. Tanji, Z. Q. Lin, N. Terry, and D. W. Peters. 2003. Selenium removal and mass balance in a constructed flow-through wetland system. J ournal of Environmental Quality 32 (4):1557-1570.

Gardner, R. C. 2009. North American wetland mitigation and restoration policies, Introduction. Wetlands Ecology and Management 17 (1):1-2. http:// www.springerlink.com/ content/ 0775264jxp45725g/fulltext.pdf

General Accounting Office (GAO). 1988. Wetlands: The Corps of Engineers' Administration of the Section 404 Program. GAO/RCED-88-110. Washington, DC: GAO. http://archive.gao.gov/d16t6/ 136780.pdf

Gillenwater, D., T. Granata, and U. Zika. 2006. GIS-based modeling of spawning habitat suitability for walleye in the Sandusky River, Ohio, and implications for dam removal and river restoration. Ecological Engineering 28 (3 SPEC. ISS.):311-323. http:// dx.doi.org/ 10.1016/j.ecoleng.2006.08.003

Gobster, P. H. 2001. Visions of nature: Conflict and compatibility in urban park restoration. Landscape and Urban Planning 56 (1-2):35-51. http: // dx.doi.org/ 10.1016/ S0169-2046(01)00164-5

Gopal, B. 2003. Perspectives on wetland science, application and policy. Hydrobiologia 490 (1):1-10. http:/ / dx.doi.org/ 10.1023/ A: 1023418911648

Gutrich, J.J., and F. J . Hitzhusen. 2004. Assessing the substitutability of mitigation wetlands for natural sites: Estimating restoration lag costs of wetland mitigation. Ecological Economics 48 (4):409-424.

http:// www.sciencedirect.com/science?_ob=ArticleURL\&_udi=B6VDY4C4W50J -

$2 \&$ user $=930810 \&$ rdoc $=1 \&$ fmt $=\&$ orig $=$ search $\&$ sort $=\mathrm{d} \&$ docanchor $=\& v i e$ $\mathrm{w}=\mathrm{C} \&$ acct $=\mathrm{C} 000048423 \&$ v version $=1 \&$ urlVersion $=0 \&$ userid $=930810 \& \mathrm{md} 5$ $=\mathrm{e} 5 \mathrm{bd} \overline{\mathrm{b}} \mathrm{dae} 95 \mathrm{af000aa} 43 \mathrm{~b} 09 \mathrm{~d} 19 \mathrm{~d} 0 \mathrm{~d} 23 \mathrm{~b} 2$

Gutrich, J . J ., K. J. Taylor, and M. S. Fennessy. 2009. Restoration of vegetation communities of created depressional marshes in Ohio and Colorado (USA): The importance of initial effort for mitigation success. Ecological Engineering 35 (3):351-368.

http:// www.sciencedirect.com/ science?_ob=MImg\&_imagekey=B6VFB4V8FFD3-1-

7\&_cdi=6006\&_user $=930810 \&$ _orig $=$ search\&_coverDate $=03 \% 2 \mathrm{~F} 04 \% 2 \mathrm{~F} 2009$ \& sk=999649996\&view =c\&wchp=dGLbVzbzS̄kzk\&md5=7e269996d7a6ed5b696a61ce4d078fdc\&ie=/ sdarticle.pdf

Hallwood, P. 2007. Contractual difficulties in environmental management: The case of wetland mitigation banking. Ecological Economics 63 (2-3):446-451. http:/ / www.sciencedirect.com/ science?_ob=ArticleURL\&_udi=B6VDY4MRNCTX-

$2 \& \_$user $=930810 \& \_r d o c=1 \& \_\mathrm{fmt}=\& \_$orig $=$search\&_sort=d\&_docanchor $=\& v i e$ $\mathrm{w}=\mathrm{c} \&$ _acct $=\mathrm{C} 000048423 \&$ version $=1 \& \_$urlVersion $=0 \&$ \& userid $=930810 \& \mathrm{md} 5$ $=3019 \mathrm{ff} 2 \mathrm{e} 1208 \mathrm{aa} 7685 \mathrm{f} 4 \mathrm{~d} 7 \mathrm{~d} 3 \mathrm{c} 3 \mathrm{fdb} 562$

Hammersmark, C. T., W. E. Fleenor, and S. G. Schladow. 2005. Simulation of flood impact and habitat extent for a tidal freshwater marsh restoration. Ecological Engineering 25 (2):137-152. http:// dx.doi.org/ 10.1016/j.ecoleng.2005.02.008 
Hay, C. H., T. G. Franti, D. B. Marx, E. J . Peters, and L. W. Hesse. 2008.

Macroinvertebrate drift density in relation to abiotic factors in the Missouri River. Hydrobiologia 598 (1):175-189. http:// dx.doi.org/ 10.1007/ s10750-0079149-3

Hey, D. L., L. S. Urban, and J . A. Kostel. 2005. Nutrient farming: The business of environmental management. Ecological Engineering 24 (4 SPEC. ISS.):279-287. http:// dx.doi.org/ 10.1016/j.ecoleng.2004.11.014

Hilderbrand, R. H., A. C. Watts, and A. M. Randle. 2005. The myths of restoration ecology. Ecology and Society 10 (1):- .

Hoeltje, S., and C. Cole. 2007. Losing function through wetland mitigation in central Pennsylvania, USA. Environmental Management 39 (3):385-402. http://dx.doi.org/ 10.1007/ s00267-006-0212-z

- 2009. Comparison of function of created wetlands of two age classes in central Pennsylvania. Environmental Management 43 (4):597-608. http:// www.springerlink.com/ content/ 5771g81311737412/ fulltext.pdf

Hoeppner, S. S., G. P. Shaffer, and T. E. Perkins. 2008. Through droughts and hurricanes: Tree mortality, forest structure, and biomass production in a coastal swamp targeted for restoration in the Mississippi River Deltaic Plain. Forest Ecology and Management 256 (5):937-948. http:// dx.doi.org/ 10.1016/j.foreco.2008.05.040

Hornyak, M. M., and K. E. Halvorsen. 2003. Wetland mitigation compliance in the Western Upper Peninsula of Michigan. Environmental Management 32 (5):535540. http:// dx.doi.org/ 10.1007/ s00267-003-2851-7

Hough, P., and M. Robertson. 2009. Mitigation under Section 404 of the Clean Water Act: Where it comes from, what it means. Wetlands Ecology and Management 17 (1):15-33. http:// dx.doi.org/ 10.1007/ s11273-008-9093-7

Huang, J . C., W. J . Mitsch, and L. Zhang. 2009. Ecological restoration design of a stream on a college campus in central Ohio. Ecological Engineering 35 (2):329-340. http:// dx.doi.org/ 10.1016/j.ecoleng.2008.07.018

ITRC Interstate Technology \& Regulatory Council. 2005. Characterization, design, construction and monitoring of mitigation wetlands. WTLND-2. 444 North Capitol Street, NW, Suite 445, Washington, DC 20001: N. C. S. Interstate Technology \& Regulatory Council, Nw, Suite 445, Washington, Dc 20001. (http:// www.itrcweb.org/ Documents/WTLND-2.pdf).

J ahr, K. J ., and G. E. Crow. 2005. Floristic reevaluation of a created wetland in Portsmouth, New Hampshire. Rhodora 107 (929):87-102.

J ohnson, P. A., and E. R. Brown. 2001. Incorporating uncertainty in the design of stream channel modifications. J ournal of the American Water Resources Association 37 (5):1225-1236.

J ohnson, P. A., R. L. Tereska, and E. R. Brown. 2002. Using technical adaptive management to improve design guidelines for urban instream structures. J ournal of the American Water Resources Association 38 (4):1143-1152. 
Julian, J . T., C. D. Snyder, and J . A. Young. 2006. The use of artificial impoundments by two amphibian species in the Delaware Water Gap National Recreation Area. Northeastern Naturalist 13 (4):459-468. http:// dx.doi.org/ 10.1656/ 10926194(2006)13[459:TUOAIB]2.0.CO; 2

Kaplowitz, M. D., and F. Lupi. 2008. What wetland bankers think about mitigation banking. J ournal of Soil and Water Conservation 63 (3):90a-90a.

Kaplowitz, M. D., F. Lupi, and D. Bailey. 2008. Wetland mitigation banking: The bankers' perspective. J ournal of Soil and Water Conservation 63 (3):162-172.

Kelly, N. M. 2001. Changes to the landscape pattern of coastal North Carolina wetlands under the Clean Water Act, 1984-1992. Landscape Ecology 16 (1):3-16. http:/ / www.springerlink.com/ content/ l2u4t31425368104/ fulltext.pdf

- 2001. Changes to the landscape pattern of coastal North Carolina wetlands under the Clean Water Act, 1984â€"1992. Landscape Ecology 16 (1):3-16. http:/ / dx.doi.org/ 10.1023/ A: 1008168322720

Kentula, M., J . Sifneos, J . Good, M. Rylko, and K. Kunz. 1992. Trends and patterns in section 404 permitting requiring compensatory mitigation in Oregon and Washington, USA. Environmental Management 16 (1):109-119. http:/ / dx.doi.org/ 10.1007/ BF02393913

Kettlewell, C. I., V. Bouchard, D. Porej, M. Micacchion, J . J . Mack, D. White, and L. Fay. 2008. An assessment of wetland impacts and compensatory mitigation in the Cuyahoga River Watershed, Ohio, USA. Wetlands 28 (1):57-67. http:/ / dx.doi.org/ 10.1672/ 07-01.1

King, D. M., and E. W. Price. 2004. Developing defensible wetland mitigation ratios: Companion to "The five-step wetland mitigation ratio Calculator." 1315 EastWest Highway, Silver Spring, MD 20910. (http:// www.nero.noaa.gov/ hcd/ socio/ FinalNOAA\%20Wetland\%20mitigation \%20ratio\%20guidance.pdf).

Knox, A. K., R. A. Dahlgren, K. W. Tate, and E. R. Atwill. 2008. Efficacy of natural wetlands to retain nutrient, sediment and microbial pollutants. J ournal of Environmental Quality 37 (5):1837-1846. http:/ / dx.doi.org/ 10.2134/ jeq2007.0067

Kondolf, G. M., M. W. Smeltzer, and S. F. Railsback. 2001. Design and performance of a channel reconstruction project in a coastal California gravel-bed stream. Environmental Management 28 (6): 761-776. http:// dx.doi.org/ 10.1007/ s002670010260

Kovacic, D. A., M. B. David, L. E. Gentry, K. M. Starks, and R. A. Cooke. 2000. Effectiveness of constructed wetlands in reducing nitrogen and phosphorus export from agricultural tile drainage. J ournal of Environmental Quality 29 (4):1262-1274.

Kowalski, K. P., D. A. Wilcox, and M. J . Wiley. 2009. Stimulating a Great Lakes coastal wetland seed bank using portable cofferdams: Implications for habitat rehabilitation. J ournal of Great Lakes Research 35 (2):206-214. http:// dx.doi.org/ 10.1016/j.jglr.2008.12.005 
Kubel, J. E., and R. h. Yahner. 2008. Quality of anthropogenic habitats for Goldenwinged Warblers in central Pennsylvania. The Wilson J ournal of Ornithology 120 (4):801-812. http:// dx.doi.org/ 10.1676/06-114.1

Kusler, J . 2006. Developing performance standards for the mitigation and restoration of northern forested wetlands. (http://www.aswm.org/propub/jon_kusler/forested_wetlands_080106.pdf).

La Peyre, M. K., M. A. Reams, and I. A. Mendelssohn. 2009. Linking actions to outcomes in wetland management: An overview of U.S. State wetland management. Wetlands 21 (1):66-74. http:// dx.doi.org/ 10.1672/02775212(2001)021[0066:LATOIW]2.0.CO; 2

Lichko, L. E., and A. J . K. Calhoun. 2003. An evaluation of vernal pool creation projects in New England: Project documentation from 1991-2000. Environmental Management 32 (1):141-151. http:// www.springerlink.com/ content/ ugq07q5ue8jha97w/ fulltext.pdf

Line, D. E., G. D. J ennings, M. B. Shaffer, J . Calabria, and W. F. Hunt. 2008. Evaluating the effectiveness of two stormwater wetlands in North Carolina. Transactions of the ASABE 51(2):521-528.

Longwell, B. 2006. Construction challenges. International Water Power and Dam Construction 58 (6):28-31.

Lott, R. B., and R. J . Hunt. 2001. Estimating evapotranspiration in natural and constructed wetlands. Wetlands 21 (4):614-628.

Mashour, T., J . Alavalapati, R. Matta, S. Larkin, and D. Carter. 2005. A hedonic analysis of the effect of natural attributes and deed restrictions on the value of conservation easements. Forest Policy and Economics 7 (5):771-781. http:// dx.doi.org/ 10.1016/j.forpol.2005.03.013

Matthews, J. W., and A. G. Endress. 2008. Performance criteria, compliance success, and vegetation development in compensatory mitigation wetlands. Environmental Management 41(1):130-141. http:/ / www.springerlink.com/ content/ b58641k31508h577/ fulltext.pdf

Mayer, P. M., and S. M. Galatowitsch. 2001. Assessing ecosystem integrity of restored prairie wetlands from species production-diversity relationships. Hydrobiologia 443:177-185. http:// dx.doi.org/ 10.1023/ A: 1017516724965

Menzel, J . M., M. A. Menzel, J . C. Kilgo, W. M. Ford, and J. W. Edwards. 2005. Bat response to Carolina bays and wetland restoration in the Southeastern US Coastal Plain. Wetlands 25 (3):542-550.

Merovich, G. T., Jr., G. T., J . M. Stiles, J . T. Petty, P. F. Ziemkiewicz, and J . B. Fulton. 2007. Water chemistry-based classification of streams and implications for restoring mined Appalachian watersheds. Environmental Toxicology and Chemistry 26 (7):1361-1369. http:/ / dx.doi.org/ 10.1897/ 06-424R.1

Miller, P. S., J . K. Mitchell, R. A. Cooke, and B. A. Engel. 2002. A wetland to improve agricultural subsurface drainage water quality. Transactions of the American Society of Agricultural Engineers 45 (5):1305-1317. 
Min, J .-H., and W. R. Wise. 2009. Simulating short-circuiting flow in a constructed wetland: The implications of bathymetry and vegetation effects. Hydrological Processes 23 (6):830-841. http:// dx.doi.org/ 10.1002/ hyp.7219

Minkin, P., and R. Ladd. 2003. Success of Corps-required wetland mitigation in New England.

Mitsch, W. J . 2005. Applying science to conservation and restoration of the world's wetlands. Water Science and Technology 51 (8):13-26.

Mitsch, W. J ., L. Zhang, C. J . Anderson, A. E. Altor, and M. E. Hernandez. 2005. Creating riverine wetlands: Ecological succession, nutrient retention, and pulsing effects. Ecological Engineering 25 (5):510-527. http:// dx.doi.org/ 10.1016/j.ecoleng.2005.04.014

Morgan, K. L., and T. H. Roberts. 2003. Characterization of wetland mitigation projects in Tennessee, USA. Wetlands 23 (1):65-69.

Moser, K., C. Ahn, and G. Noe. 2007. Characterization of microtopography and its influence on vegetation patterns in created wetlands. Wetlands 27 (4):1081-1097.

Muehlbauer, J . D., C. J . LeRoy, J . M. Lovett, K. K. Flaccus, J . K. Vlieg, and J . C. Marks. 2009. Short-term responses of decomposers to flow restoration in Fossil Creek, Arizona, USA. Hydrobiologia 618 (1):35-45. http: / dx.doi.org/ 10.1007/ s10750008-9545-3

Muir Hotaling, N. E., W. J . Kuenzel, and L. W. Douglass. 2002. Breeding season bird use of restored wetlands in eastern Maryland. Southeastern Naturalist 1(3):233-252. http:/ / dx.doi.org/ 10.1656/ 1528- 7092(2002)001[0233:BSBUOR]2.0.CO;2

Nahlik, A. M., and W. J . Mitsch. 2008. The effect of river pulsing on sedimentation and nutrients in created riparian wetlands. J ournal of Environmental Quality 37 (4):1634-1643. http: / / dx.doi.org/ 10.2134/jeq2007.0116

Neary, V. S., S. A. Wright, and P. Bereciartua. 2001. Case study: Sediment transport in proposed geomorphic channel for Napa River. J ournal of Hydraulic Engineering 127 (11):901-910. http:// dx.doi.org/ 10.1061/ (ASCE)0733-9429(2001)127:11(901)

Nemerson, D. M., and K. W. Able. 2005. J uvenile sciaenid fishes respond favorably to Delaware Bay marsh restoration. Ecological Engineering 25 (3):260-274. http:// www.sciencedirect.com/science?_ob=MImg\&_imagekey=B6VFB4GV9SC3-1-

K\&_cdi $=6006 \&$ user $=930810 \&$ \& orig $=$ search\&_coverDate $=09 \% 2 \mathrm{~F} 20 \% 2 \mathrm{~F} 2005$ \& sk=999749996\&view=c\&wchp=dGLzVtbzSkWb\&md5=ef574d45496c70bf4bfcddf4580900f9\&ie=/ sdarticle.pdf

Ng, T. L., and J. W. Eheart. 2008. A multiple-realizations chance-constrained model for optimizing nutrient removal in constructed wetlands. Water Resources Research 44 (4). http: / / dx.doi.org/ 10.1029/2007WR006126

Nie, M. 2008. The underappreciated role of regulatory enforcement in natural resource conservation. Policy Sciences 41 (2):139-164. http:// dx.doi.org/ 10.1007/ s11077008-9060-4 
Niezgoda, S. L., and P. A. J ohnson. 2007. Case study in cost-based risk assessment for selecting a stream restoration design method for a channel relocation project. J ournal of Hydraulic Engineering 133 (5):468-481. http://dx.doi.org/ 10.1061/ (ASCE)0733-9429(2007)133:5(468)

National Research Council (NRC). 2001. Compensating for wetland losses under the Clean Water Act. National Academy Press, Washington, D.C. http:// www.nap.edu/catalog.php?record_id=10134

O'Neal, B. J ., E. J . Heske, and J . D. Stafford. 2008. Waterbird response to wetlands restored through the Conservation Reserve Enhancement Program. J ournal of Wildlife Management 72 (3):654-664. http: / / dx.doi.org/ 10.2193/ 2007-165

Owen, C., and H. J acobs. 1992. Wetland protection as land-use planning: The impact of Section 404 in Wisconsin, USA. Environmental Management 16 (3):345-353. http:// dx.doi.org/ 10.1007/BF02400073

Palmer, M. A., and E. S. Bernhardt. 2006. Hydroecology and river restoration: Ripe for research and synthesis. Water Resources Research 42 (3). http:/ / dx.doi.org/ 10.1029/ 2005WR004354

Pankratz, S., T. Young, H. Cuevas-Arellano, R. Kumar, R. F. Ambrose, and I. H. Suffet. 2007. The ecological value of constructed wetlands for treating urban runoff. Water Science and Technology 55 (3):63-69. http:// dx.doi.org/ 10.2166/ wst.2007.073

Pechmann, J . H. K., R. A. Estes, D. E. Scott, and J . Whitfield Gibbons. 2001. Amphibian colonization and use of ponds created for trial mitigation of wetland loss. Wetlands 21 (1):93-111. http: / / dx.doi.org/ 10.1672/ 0277-

5212(2001)021[0093:ACAUOP]2.0.CO;2

Peterson, C. H., and R. N. Lipcius. 2003. Conceptual progress towards predicting quantitative ecosystem benefits of ecological restorations. Marine EcologyProgress Series 264:297-307.

Piegay, H., K. J . Gregory, V. Bondarev, A. Chin, N. Dahlstrom, A. Elosegi, S. V. Gregory, V. J oshi, M. Mutz, M. Rinaldi, B. Wyzga, and J . Zawiejska. 2005. Public perception as a barrier to introducing wood in rivers for restoration purposes. Environmental Management 36 (5):665-674. http:// dx.doi.org/ 10.1007/ s00267-004-0092-z

Pollock, M. M., T. J . Beechie, and C. E. J ordan. 2007. Geomorphic changes upstream of beaver dams in Bridge Creek, an incised stream channel in the interior Columbia River basin, eastern Oregon. Earth Surface Processes and Landforms 32 (8):1174-1185. http:// dx.doi.org/ 10.1002/ esp.1553

Ponader, K. C., D. F. Charles, and T. J . Belton. 2007. Diatom-based TP and TN inference models and indices for monitoring nutrient enrichment of NewJ ersey streams. Ecological Indicators 7 (1):79-93. http:// dx.doi.org/ 10.1016/j.ecolind.2005.10.003 
Poplar-J effers, I. O., J. T. Petty, J. T. Anderson, S. J . Kite, M. P. Strager, and R. H. Fortney. 2009. Culvert replacement and stream habitat restoration: Implications from brook trout management in an Appalachian Watershed, USA. Restoration Ecology 17 (3):404-413.

Postel, S. 2002. Rivers of life: The challenge of restoring health to freshwater ecosystems. Water Science and Technology 45 (11):3-8.

Priddel, D. 2008. Compensatory mitigation. Frontiers in ecology and the environment $6(2): 68-68$.

Quigley, J., and D. Harper. 2006. Effectiveness of fish habitat compensation in Canada in achieving no net loss. Environmental Management 37 (3):351-366.

http:// dx.doi.org/ 10.1007/ s00267-004-0263-y

Robb, J . T. 2002. Assessing wetland compensatory mitigation sites to aid in establishing mitigation ratios. Wetlands $22(2): 435-440$.

Robertson, M. 2009. The work of wetland credit markets: Two cases in entrepreneurial wetland banking. Wetlands Ecology and Management 17 (1):35-51. http:/ / www.springerlink.com/ content/ 1187t01u63480784/ fulltext.pdf

Robertson, M., and N. Hayden. 2008. Evaluation of a market in wetland credits: Entrepreneurial wetland banking in Chicago. Conservation Biology 22 (3):636646.

Rolband, M. S. 2008. Response to stream mitigation. Civil Engineering 78 (7):10-10.

Roseman, E. F., G. W. Kennedy, J. Boase, B. A. Manny, T. N. Todd, and W. Stott. 2007. Evidence of lake whitefish spawning in the Detroit River: Implications for habitat and population recovery. J ournal of Great Lakes Research 33 (2):397-406.

Rosi-Marshall, E. J ., A. H. Moerke, and G. A. Lamberti. 2006. Ecological responses to trout habitat rehabilitation in a Northern Michigan stream. Environmental Management 38 (1):99-107. http:/ / dx.doi.org/ 10.1007/ s00267-005-0177-3

Rossell, I. M., K. K. Moorhead, H. Alvarado, and R. J. Warren. 2009. Succession of a southern Appalachian mountain wetland six years following hydrologic and microtopographic restoration. Restoration Ecology 17 (2):205-214.

Rubec, C. D. A., and A. R. Hanson. 2009. Wetland mitigation and compensation: Canadian experience. Wetlands Ecology and Management 17 (1):3-14. http:// www.springerlink.com/ content/10r839236g2lw114/ fulltext.pdf

Schweiger, E. W., S. G. Leibowitz, J . B. Hyman, W. E. Foster, and M. C. Downing. 2002. Synoptic assessment of wetland function: a planning tool for protection of wetland species biodiversity. Biodiversity and Conservation 11 (3):379-406. http:// dx.doi.org/ 10.1023/ A: 1014814226148

Sheibley, R. W., D. S. Ahearn, and R. A. Dahlgren. 2006. Nitrate loss from a restored floodplain in the Lower Cosumnes River, California. Hydrobiologia 571 (1):261272. http:// dx.doi.org/ 10.1007/ s10750-006-0249-2 
Shields, F. D., C. M. Cooper Jr., S. S. Knight, and M. T. Moore. 2003. Stream corridor restoration research: A long and winding road. Ecological Engineering 20 (5):441-454.

Shields, F. D., J r., S. S. Knight, N. Morin, and J . Blank. 2003. Response of fishes and aquatic habitats to sand-bed stream restoration using large woody debris. Hydrobiologia 494:251-257. http:/ / dx.doi.org/ 10.1023/ A: 1025434920429

Shields, F. D., Jr., R. R. Copeland, P. C. Klingeman, M. W. Doyle, and A. Simon. 2003. Design for stream restoration. J ournal of Hydraulic Engineering 129 (8):575584 .

Sidle, W. C., and J . A. Goodrich. 2003. Denitrification efficiency in groundwater adjacent to ditches within constructed riparian wetlands: Kankakee watershed, IllinoisIndiana, U.S.A. Water, Air, and Soil Pollution 144 (1-4):391-404. http:// dx.doi.org/ 10.1023/ A: 1022962127801

Sifneos, J ., E. Cake, and M. Kentula. 1992. Effects of Section 404 permitting on freshwater wetlands in Louisiana, Alabama, and Mississippi. Wetlands 12 (1):2836. http:// dx.doi.org/ 10.1007/BF03160541

Siragusa, K. S. 2008. Integrating a watershed approach into Clean Water Act Section 404, wetland and stream compensatory mitigation lessons learned and recommendations for Georgia. Internet Resource; Archival Material Date of Entry: 20090824.

http:// purl.galileo.usg.edu/ uga\%5Fetd/ siragusa\%5Fkelly\%5F200805\%5Fms

Slate, L. O., D. F. Shields, J . S. Schwartz, D. D. Carpenter, and G. E. Freeman. 2007. Engineering design standards and liability for stream channel restoration. J ournal of Hydraulic Engineering 133 (10):1099-1102. http:/ / dx.doi.org/ 10.1061/ (ASCE)0733-9429(2007)133: 10(1099)

Smiley, P. C., J r., and E. D. Dibble. 2005. Implications of a hierarchical relationship among channel form, instream habitat, and stream communities for restoration of channelized streams. Hydrobiologia 548 (1):279-292. http:/ / dx.doi.org/ 10.1007/ s10750-005-5447-9

Smiley, P. C., J r., and E. D. Dibble. 2005. Implications of a hierarchical relationship among channel form, instream habitat, and stream communities for restoration of channelized streams. Hydrobiologia 548 (1):279-292.

Smith, S. M., and K. L. Prestegaard. 2005. Hydraulic performance of a morphology-based stream channel design. Water Resources Research 41(11):1-17. http:/ / dx.doi.org/ 10.1029/ 2004WR003926

Sonntag, D. H., and C. A. Cole. 2008. Determining the feasibility and cost of an ecologically-based design for a mitigation wetland in central Pennsylvania, USA. Landscape and Urban Planning 87 (1):10-21. http:// dx.doi.org/ 10.1016/j.landurbplan.2008.03.008

Spieles, D. J . 2005. Vegetation development in created, restored, and enhanced mitigation wetland banks of the United States. Wetlands 25 (1):51-63. 
Spieles, D. J., M. Coneybeer, and J . Horn. 2006. Community structure and quality after 10 years in two central Ohio mitigation bank wetlands. Environmental Management 38 (5):837-852.

Steiner, F., S. Pieart, E. Cook, J . Rich, and V. Coltman. 1994. State wetlands and riparian area protection programs. Environmental Management 18 (2):183-201. http:// dx.doi.org/ 10.1007/ BF02393761

Stokstad, E. 2008. Environmental regulation: New rules on saving wetlands push the limits of the science. Science 320 (5873):162-163.

Sudol, M. F., and R. F. Ambrose. 2002. The US Clean Water Act and habitat replacement: Evaluation of mitigation sites in Orange County, California, USA. Environmental Management 30 (5): 727-734.

http:// www.springerlink.com/ content/ kle5g5f92434t9cf/ fulltext.pdf

Sullivan, P. J., J . M. Acheson, P. L. Angermeier, T. Faast, J . Flemma, C. M. J ones, E. E. Knudsen, T. J . Minello, D. H. Secor, R. Wunderlich, and B. A. Zanetell. 2006. Defining and implementing - Best available science for fisheries and environmental science, policy, and management. Fisheries 31 (9):460-465.

Sutton-Grier, A. E., J . Pahl, M. Ho, and C. Richardson. 2005. Increasing vegetation, improving water: Compost use in urban restored wetlands. BioCycle 46 (10):4041.

Sweka, J . A., and K. J . Hartman. 2006. Effects of large woody debris addition on stream habitat and brook trout populations in Appalachian streams. Hydrobiologia 559 (1):363-378. http:// dx.doi.org/ 10.1007/ s10750-005-9117-8

Tanji, K. K., and Keyes, J r. 2002. Water quality aspects of irrigation and drainage: Past history and future challenges for civil engineers. J ournal of Irrigation and Drainage Engineering 128 (6):332-340. http:/ / dx.doi.org/ 10.1061/ (ASCE)07339437(2002)128:6(332)

Taylor, J ., and B. A. Middleton. 2004. Comparison of litter decomposition in a natural versus coal-slurry pond reclaimed as a wetland. Land Degradation and Development 15 (4):439-446. http:// dx.doi.org/ 10.1002/ldr.625

Thompson, D. M. 2002. Long-term effect of instream habitat-improvement structures on channel morphology along the Blackledge and Salmon rivers, Connecticut, USA. Environmental Management 29 (2):250-265. http:// dx.doi.org/ 10.1007/ s00267-001-0069-0

Thorne, J . H., P. R. Huber, E. H. Girvetz, J . Quinn, and M. C. McCoy. 2009. Integration of regional mitigation assessment and conservation planning. Ecology and Society 14 (1):- .

Torok, L., S. Lockwood, and D. Fanz. 1996. Review and comparison of wetland impacts and mitigation requirements between NewJ ersey, USA, Freshwater Wetlands Protection Act and Section 404 of the Clean Water Act. Environmental Management 20 (5):741-752. http:// dx.doi.org/ 10.1007/ BF01204145 
Tullos, D. D., D. L. Penrose, and G. D. J ennings. 2006. Development and application of a bioindicator for benthic habitat enhancement in the North Carolina Piedmont. Ecological Engineering 27 (3):228-241. http:// dx.doi.org/10.1016/j.ecoleng.2006.03.001

Tweedy, K. L., and R. O. Evans. 2001. Hydrologic characterization of two prior converted wetland restoration sites in eastern north carolina. Transactions of the American Society of Agricultural Engineers 44 (5):1135-1142.

U.S. Army Corps of Engineers and U.S. Environmental Protection Agency. 1990. Memorandum of Agreement Between The Department of the Army and The Environmental Protection Agency: The Determination of Mitigation under the Clean Water Act Section 404(b)(1) Guidelines. Washington, DC: http://www.usace.army.mil/ CECW/ Documents/ cecwo/reg/ mou/migrate.pdf

Ullah, S., and S. P. Faulkner. 2006. Use of cotton gin trash to enhance denitrification in restored forested wetlands. Forest Ecology and Management 237 (1-3):557-563. http:/ / dx.doi.org/ 10.1016/j.foreco.2006.09.075

Van Lonkhuyzen, R. A., K. E. Lagory, and J . A. Kuiper. 2004. Modeling the suitability of potential wetland mitigation sites with a geographic information system. Environmental Management 33 (3):368-375.

Vepraskas, M. J ., R. L. Huffman, and G. S. Kreiser. 2006. Hydrologic models for altered landscapes. Geoderma 131(3-4):287-298. http:/ / dx.doi.org/ 10.1016/j.geoderma.2005.03.010

Vymazal, J . 2007. Removal of nutrients in various types of constructed wetlands. Science of the Total Environment 380 (1-3):48-65. http:// dx.doi.org/ 10.1016/j.scitotenv.2006.09.014

Walther, D. A., and M. R. Whiles. 2008. Macroinvertebrate responses to constructed riffles in the Cache River, Illinois, USA. Environmental Management 41 (4):516527. http:// dx.doi.org/ 10.1007/ s00267-007-9058-2

Wardrop, D. H., M. E. Kentula, D. L. Stevens, S. F. J ensen, and R. P. Brooks. 2007. Assessment of wetland condition: An example from the upper J uniata watershed in Pennsylvania, USA. Wetlands 27 (3):416-431. http:/ / dx.doi.org/ 10.1672/ 02775212(2007)27[416:AOWCAE]2.0.CO;2

Warren, D. R., C. E. Kraft, W. S. Keeton, J . S. Nunery, and G. E. Likens. 2009. Dynamics of wood recruitment in streams of the northeastern US. Forest Ecology and Management 258 (5):804-813. http:// dx.doi.org/ 10.1016/j.foreco.2009.05.020

Weis, J . S., and P. Weis. 2004. Metal uptake, transport and release by wetland plants: Implications for phytoremediation and restoration. Environment International 30 (5):685-700. http:// dx.doi.org/ 10.1016/j.envint.2003.11.002

Weishar, L. L., J . M. Teal, and R. Hinkle. 2005. Designing large-scale wetland restoration for Delaware Bay. Ecological Engineering 25 (3):231-239. http:/ / dx.doi.org/ 10.1016/j.ecoleng.2005.04.012

Whalen, P. J ., L. A. Toth, J . W. Koebel, and P. K. Strayer. 2002. Kissimmee River restoration: A case study. Water Science and Technology 45 (11):55-62. 
White, D., and S. Fennessy. 2005. Modeling the suitability of wetland restoration potential at the watershed scale. Ecological Engineering 24 (4):359-377.

White, K. 2001. Preservation of wetlands on the federal-aid highway system. Public Roads 64 (4):26-29.

Wilcox, D. A., M. J . Sweat, M. L. Carlson, and K. P. Kowalski. 2006. A water-budget approach to restoring a sedge fen affected by diking and ditching. J ournal of Hydrology 320 (3-4):501-517. http:// dx.doi.org/ 10.1016/j.jhydrol.2005.07.026

Wilkinson, J . 2009. In-lieu fee mitigation: coming into compliance with the new Compensatory Mitigation Rule. Wetlands Ecology and Management 17 (1):5370. http:// www.springerlink.com/ content/y5538766x2551382/ fulltext.pdf

Williams, C. F., and F. J . Adamsen. 2008. A low-cost three-dimensional sample collection array to evaluate and monitor constructed wetlands. Ecological Engineering 33 (1):83-90. http:// dx.doi.org/ 10.1016/j.ecoleng.2008.02.006

Woltemade, C. J ., and J . Woodward. 2008. Nitrate removal in a restored spring-fed wetland, Pennsylvania, USA. J ournal of the American Water Resources Association 44 (1):222-234. http: / / dx.doi.org/ 10.1111/j.1752-1688.2007.00149.x 


\section{Appendix N: Roads}

Abella, S. R., J . E. Spencer, J . Hoines, and C. Nazarchyk. 2009. Assessing an exotic plant surveying program in the Mojave Desert, Clark County, Nevada, USA. Environmental Monitoring and Assessment 151 (1-4):221-230. http://dx.doi.org/ 10.1007/s10661-008-0263-0

Akay, A. E., and J . Sessions. 2005. Applying the decision support system, TRACER, to forest road design. Western J ournal of Applied Forestry 20 (3):184-191.

Aldrich, J ., M. Vilem, and M. Oakland. 2003. A culvert for Abram Creek. Civil Engineering 73 (11):64-69.

Appelboom, T., G. Chescheir, R. Skaggs, and D. Hesterberg. 2002. Management practices for sediment reduction from forest roads in the coastal plain. Transactions of the ASAE 45 (2):337-344.

Aruga, K., J . Sessions, and E. S. Miyata. 2005. Forest road design with soil sediment evaluation using a high-resolution DEM. J ournal of Forest Research 10 (6):471479. http:// dx.doi.org/ 10.1007/ s10310-005-0174-7

Aust, W. M., R. Visser, T. Gallagher, T. Roberts, and M. Poirot. 2003. Cost of six different stream crossing options in the Appalachian area. Southern J ournal of Applied Forestry 27 (1):66-70.

Beschta, R. L., M. R. Pyles, A. E. Skaugset, and C. G. Surfleet. 2000. Peakflow responses to forest practices in the western cascades of Oregon, USA. J ournal of Hydrology 233 (1-4):102-120. http:// dx.doi.org/ 10.1016/ S0022-1694(00)00231-6

Bhagat, Y., J . J . H. Ciborowski, L. B. J ohnson, D. G. Uzarski, T. M. Burton, S. T. A. Timmermans, and M.J . Cooper. 2007. Testing a fish index of biotic integrity for responses to different stressors in Great Lakes coastal wetlands. J ournal of Great Lakes Research 33 (SPEC. ISS. 3):224-235. http: // dx.doi.org/ 10.3394/ 03801330(2007)33[224:TAFIOB]2.0.CO;2

Bhatia, S. K., J . L. Smith, D. Lake, and D. Walowsky. 2002. A technical and economic evaluation of geosynthetic rolled erosion control products in highway drainage channels. Geosynthetics International 9 (2):125-148.

Blasius, B. J ., and R. W. Merritt. 2002. Field and laboratory investigations on the effects of road salt $(\mathrm{NaCl})$ on stream macroinvertebrate communities. Environmental Pollution 120 (2):219-231. http:// dx.doi.org/ 10.1016/ S0269-7491(02)00142-2

Briaud, J .-L. 2006. Bridge scour. Geotechnical News 24 (3):54-56.

Briaud, J . L., H. C. Chen, Y. Li, P. Nurtjahyo, and J . Wang. 2005. SRICOS-EFA method for contraction scour in fine-grained soils. J ournal of Geotechnical and Geoenvironmental Engineering 131(10):1283-1294. http:// dx.doi.org/ 10.1061/(ASCE)1090-0241(2005)131:10(1283) 
Brooks, E. S., J . Boll, W. J . Elliot, and T. Dechert. 2006. Global positioning system/ GISbased approach for modeling erosion from large road networks. J ournal of Hydrologic Engineering 11 (5):418-426. http:/ / dx.doi.org/ 10.1061/ (ASCE)10840699(2006)11:5(418)

Bryce, S. A. 2006. Development of a bird integrity index: Measuring avian response to disturbance in the Blue Mountains of Oregon, USA. Environmental Management 38 (3):470-486. http:/ / dx.doi.org/ 10.1007/ s00267-005-0152-z

Camponelli, K. M., R. E. Casey, J . W. Snodgrass, S. M. Lev, and E. R. Landa. 2009. Impacts of weathered tire debris on the development of Rana sylvatica larvae. Chemosphere 74 (5): 717-722.

http:// dx.doi.org/ 10.1016/j.chemosphere.2008.09.056

Carr, L. W., L. Fahrig, and S. E. Pope. 2002. Impacts of landscape transformation by roads. In Applying Landscape Ecology in Biological Conservation. New York: Springer-Verlag.

Cavalcanti, G. G., and B. Graeme Lockaby. 2005. Effects of sediment deposition on fine root dynamics in riparian forests. Soil Science Society of America J ournal 69 (3): 729-737. http:// dx.doi.org/ 10.2136/ sssaj2004.0239

Cazenas, P. A. 2005. On the road to environmental excellence. Public Roads 69 (3).

Chang, H. H. 2001. Sediment transport modeling for bridge scour downstream of a dam. Applied Engineering in Agriculture 17 (6):803-805.

Chen, Y., R. C. Viadero J r, X. Wei, R. Fortney, L. B. Hedrick, S. A. Welsh, J. T. Anderson, and L.-S. Lin. 2009. Effects of highway construction on stream water quality and macroinvertebrate condition in a Mid-Atlantic Highlands watershed, USA. J ournal of Environmental Quality 38 (4):1672-1682. http:/ / dx.doi.org/ 10.2134/ jeq2008.0423

Clinton, B. D., and J . M. Vose. 2003. Differences in surface water quality draining four road surface types in the Southern Appalachians. Southern J ournal of Applied Forestry 27 (2):100-106.

Councell, T. B., K. U. Duckenfield, E. R. Landa, and E. Callender. 2004. Tire-wear particles as a source of zinc to the environment. Environmental Science and Technology 38 (15):4206-4214. http:// dx.doi.org/ 10.1021/ es034631f

Cupp, C. E. 2003. Influence of culvert crossings on movement of stream dwelling salmonids. NCASI Technical Bulletin (862):1-12.

Davis, C. T., and W. K. Clatterbuck. 2003. Role of the Tennessee master logger program in implementation of best management practices on non-industrial private forests. Southern J ournal of Applied Forestry 27 (1):36-40.

Dolah, R. F., G. H. M. Riekerk, M. V. Levisen, G. I. Scott, M. H. Fulton, D. Bearden, S. Sivertsen, K. W. Chung, and D. M. Sanger. 2005. An evaluation of polycyclic aromatic hydrocarbon (PAH) runoff from highways into estuarine wetlands of South Carolina. Archives of Environmental Contamination and Toxicology 49 (3):362-370. http:// dx.doi.org/ 10.1007/ s00244-004-0210-1 
Downs, A. 2003. Why Florida's concurrency principles (for controlling new development by regulating road construction) do not - and cannot: Work effectively. Transportation Quarterly 57 (1):13-18.

Endreny, T. A., and K. E. Thomas. 2009. Improving estimates of simulated runoff quality and quantity using road-enhanced land cover data. J ournal of Hydrologic Engineering 14 (4):346-351. http:// dx.doi.org/ 10.1061/ (ASCE)10840699(2009)14:4(346)

Findlay, C. S., and J . Bourdages. 2000. Response time of wetland biodiversity to road construction on adjacent lands. Conservation Biology 14 (1):86-94. http:/ / www.jstor.org/ stable/ 2641907

Fitch, G. M., and J . E. Anderson. 2001. Use of digital multispectral videography to capture environmental data sets for Virginia Department of Transportation. Transportation Research Record (1756):87-93.

Fitch, G. M., and D. S. Roosevelt. 2000. Environmental implications of the use of "Ice Ban" as a prewetting agent for sodium chloride. Transportation Research Record (1700):32-37.

Forman, R. T. T. 2000. Estimate of the area affected ecologically by the road system in the United States. Conservation Biology 14 (1):31-35. http:// www.jstor.org/ stable/ 2641901

Forman, R. T. T., and R. D. Deblinger. 2000. The ecological road-effect zone of a Massachusetts (USA) suburban highway. Conservation Biology 14 (1):36-46.

Forman, R. T. T., D. Sperling, J . A. Bissonette, A. P. Clevenger, C. D. Cutshall, V. H. Dale, L. Fahrig, R. France, C. R. Goldman, K. Heanue, J . A. J ones, F. J . Swanson, T. Turrentine, and T. C. Winter, eds. 2003. Road Ecology Science and Solutions. Washington, D.C.: Island Press.

Frair, J . L., E. H. Merrill, H. L. Beyer, and J . M. Morales. 2008. Thresholds in landscape connectivity and mortality risks in response to growing road networks. J ournal of Applied Ecology 45(5):1504-1513.

Galbraith, H. S., C. C. Vaughn, and C. K. Meier. 2008. Environmental variables interact across spatial scales to structure trichopteran assemblages in Ouachita Mountain rivers. Hydrobiologia 596 (1):401-411. http: / / dx.doi.org/ 10.1007/ s10750-0079124-z

Gertler, A., H. Kuhns, M. Abu-Allaban, C. Damm, J . Gillies, V. Etyemezian, R. Clayton, and D. Proffitt. 2006. A case study of the impact of winter road sand/ salt and street sweeping on road dust re-entrainment. Atmospheric Environment 40 (31):5976-5985. http:// dx.doi.org/ 10.1016/j.atmosenv.2005.12.047 
Glista, D. J ., T. L. Devault, and J . A. Dewoody. 2009. A review of mitigation measures for reducing wildlife mortality on roadways. Landscape and Urban Planning 91(1):1-7.

http://www.sciencedirect.com/science?_ob=ArticleURL\&_udi=B6V914V5GCN1-

$1 \&$ user $=930810 \&$ rdoc $=1 \&$ fmt $=\& \_$orig $=$search\&_sort=d\&_docanchor $=\& v i e$ $\mathrm{w}=\mathrm{c} \&$ acct $=\mathrm{C} 000048423 \&$ version $=1 \&$ _ urlVersion $=0 \&$ \& userid $=930810 \& \mathrm{md} 5$ $=c 845 \mathrm{~d} 9$ efa5b400381277282d95bdf114

Godwin, K. S., S. D. Hafner, and M. F. Buff. 2003. Long-term trends in sodium and chloride in the Mohawk River, New York: The effect of fifty years of road-salt application. Environmental Pollution 124 (2):273-281. http:// dx.doi.org/ 10.1016/ S0269-7491(02)00481-5

Hall, M., and S. Moler. 2006. Mimicking mother nature. Public Roads 69 (4).

Hedrick, K. P., R. B. Robinson, B. Tschantz, and S. E. Moore. 2006. Impact of tunnel reconstruction on stream water quality in Great Smoky Mountains National Park. J ournal of Hydrologic Engineering 11 (6):570-577. http:// dx.doi.org/ 10.1061/ (ASCE)1084-0699(2006)11:6(570)

Herb, W. R., B. J anke, O. Mohseni, and H. G. Stefan. 2008. Ground surface temperature simulation for different land covers. J ournal of Hydrology 356 (3-4):327-343. http:// dx.doi.org/ 10.1016/j.jhydrol.2008.04.020

House, M. R., M. R. Pyles, and D. White. 2005. Velocity distributions in streambed simulation culverts used for fish passage. J ournal of the American Water Resources Association 41(1):209-217.

J anke, B. D., W. R. Herb, O. Mohseni, and H. G. Stefan. 2009. Simulation of heat export by rainfall-runoff from a paved surface. J ournal of Hydrology 365 (3-4):195-212. http:// dx.doi.org/ 10.1016/j.jhydrol.2008.11.019

J ha, M. K. 2003. Criteria-based decision support system for selecting highway alignments. J ournal of Transportation Engineering 129 (1):33-41. http:// dx.doi.org/ 10.1061/ (ASCE)0733-947X(2003)129: 1(33)

J ohnson, P. A. 2005. Preliminary assessment and rating of stream channel stability near bridges. J ournal of Hydraulic Engineering 131 (10):845-852. http:/ / dx.doi.org/ 10.1061/ (ASCE)0733-9429(2005)131: 10(845)

J ohnson, P. A., and E. R. Brown. 2000. Stream assessment for multicell culvert use. J ournal of Hydraulic Engineering 126 (5):381-386. http:// dx.doi.org/ 10.1061/(ASCE)0733-9429(2000)126:5(381)

J ohnson, P. A., R. D. Hey, E. R. Brown, and D. L. Rosgen. 2002. Stream restoration in the vicinity of bridges. J ournal of the American Water Resources Association 38 (1):55-67.

J ones, J . A., F. J . Swanson, B. C. Wemple, and K. U. Snyder. 2000. Effects of roads on hydrology, geomorphology, and disturbance patches in stream networks. Conservation Biology 14 (1):76-85. http:// www.jstor.org/ stable/ 2641906 
Karwan, D. L., J . A. Gravelle, and J . A. Hubbart. 2007. Effects of timber harvest on suspended sediment loads in Mica Creek, Idaho. Forest Science 53 (2):181-188.

Kayhanian, M., C. Stransky, S. Bay, S. L. Lau, and M. K. Stenstrom. 2008. Toxicity of urban highway runoff with respect to storm duration. Science of the Total Environment 389 (2-3):386-406. http:// dx.doi.org/ 10.1016/j.scitotenv.2007.08.052

Kelly, V. R., G. M. Lovett, K. C. Weathers, S. E. G. Findlay, D. L. Strayer, D. J . Burns, and G. E. Likens. 2008. Long-term sodium chloride retention in a rural watershed: Legacy effects of road salt on streamwater concentration. Environmental Science and Technology 42 (2):410-415. http:/ / dx.doi.org/ 10.1021/ es0 71391l

Kosicki, A. J ., and S. R. Davis. 2001. Consideration of stream morphology in culvert and bridge design. Transportation Research Record (1743):57-59.

Loague, K., and J . E. Vanderkwaak. 2002. Simulating hydrological response for the R-5 catchment: Comparison of two models and the impact of the roads. Hydrological Processes 16 (5):1015-1032. http:// dx.doi.org/ 10.1002/ hyp.316

Loehle, C., T. B. Wigley, P. A. Shipman, S. F. Fox, S. Rutzmoser, R. E. Thill, and M. A. Melchiors. 2005. Herpetofaunal species richness responses to forest landscape structure in Arkansas. Forest Ecology and Management 209 (3):293-308. http:/ / dx.doi.org/ 10.1016/j.foreco.2005.02.007

Loehle, C., T. B. Wigley, S. Rutzmoser, J . A. Gerwin, P. D. Keyser, R. A. Lancia, C. J . Reynolds, R. E. Thill, R. Weih, D. WhiteJr, and P. B. Wood. 2005. Managed forest landscape structure and avian species richness in the southeastern US. Forest Ecology and Management 214 (1-3):279-293. http:// dx.doi.org/ 10.1016/j.foreco.2005.04.018

Madej, M. A. 2001. Erosion and sediment delivery following removal of forest roads. Earth Surface Processes and Landforms 26 (2):175-190. http:// dx.doi.org/ 10.1002/ 1096-9837(200102)26: 2<175: :AIDESP174>3.0.CO;2-N

Madej, M. A., E. A. Eschenbach, C. Diaz, R. Teasley, and K. Baker. 2006. Optimization strategies for sediment reduction practices on roads in steep, forested terrain. Earth Surface Processes and Landforms 31 (13):1643-1656. http:// dx.doi.org/ 10.1002/ esp.1436

Megahan, W. F., M. Wilson, and S. B. Monsen. 2001. Sediment production from granitic cutslopes on forest roads in Idaho, USA. Earth Surface Processes and Landforms 26 (2):153-163. http:// dx.doi.org/ 10.1002/ 1096-9837(200102)26:2<153: :AIDESP172>3.0.CO;2-0

Mitchell, G. F., C. L. Hunt, and Y. Su. 2002. Mitigating highway runoff constituents via a wetland. Transportation Research Record (1808):127-133.

Noll, M. R., and E. A. Magee. 2009. Quantification of phosphorus sources to a small watershed: A case study of Graywood Gully, Conesus Lake, NY.J ournal of Great Lakes Research 35 (SUPPL. 1):50-55.

http:// dx.doi.org/ 10.1016/j.jglr.2008.09.005 
Novotny, E. V., D. Murphy, and H. G. Stefan. 2008. Increase of urban lake salinity by road deicing salt. Science of the Total Environment 406 (1-2):131-144. http:// dx.doi.org/ 10.1016/j.scitotenv.2008.07.037

Padgett, P. E., D. Meadows, E. Eubanks, and W. E. Ryan. 2008. Monitoring fugitive dust emissions from off-highway vehicles traveling on unpaved roads and trails using passive samplers. Environmental Monitoring and Assessment 144 (1-3):93-103. http:/ / dx.doi.org/ 10.1007/ s10661-007-9948-z

Price, D. J ., and W. J . Birge. 2005. Effectiveness of stream restoration following highway reconstruction projects on two freshwater streams in Kentucky. Ecological Engineering 25 (1):73-84. http:// dx.doi.org/10.1016/j.ecoleng.2005.03.002

Rackley, J ., and W. Chung. 2008. Incorporating forest road erosion into forest resource transportation planning: A case study in the Mica Creek watershed in Northern Idaho. Transactions of the ASABE 51(1):115-127.

Rhee, H., J . L. Fridley, and R. B. Foltz. 2004. Modeling erosion from unpaved forest roads at various levels of geometric detail using the WEPP model. Transactions of the American Society of Agricultural Engineers 47 (3):961-968.

Rhodes, A. L., R. M. Newton, and A. Pufall. 2001. Influences of land use on water quality of a diverse New England watershed. Environmental Science and Technology 35 (18):3640-3645. http: / dx.doi.org/ 10.1021/ es002052u

Richmond, M. C., Z. Deng, G. R. Guensch, H. Tritico, and W. H. Pearson. 2007. Mean flow and turbulence characteristics of a full-scale spiral corrugated culvert with implications for fish passage. Ecological Engineering 30 (4):333-340. http:// dx.doi.org/ 10.1016/j.ecoleng.2007.04.011

Riitters, K. H., and J . D. Wickham. 2003. How far to the nearest road? Frontiers in Ecology and the Environment 1(3):125-129. http:// www.jstor.org/ stable/ 3867984

Riitters, K. H., and J. W. Coulston. 2005. Hot spots of perforated forest in the eastern United States. Environmental Management 35 (4):483-492. http:// dx.doi.org/ 10.1007/ s00267-003-0220-1

Rogers, T., and S. Mead. 2002. Low-impact construction techniques. Construction Specifier 55 (7):54-60.

Rosfjord, C. H., K. E. Webster, J . S. Kahl, S. A. Norton, I. J . Fernandez, and A. T. Herlihy. 2007. Anthropogenically driven changes in chloride complicate interpretation of base cation trends in lakes recovering from acidic deposition. Environmental Science and Technology 41 (22):7688-7693. http:// dx.doi.org/ 10.1021/ es062334f

Rowland, E. R., R. H. Hotchkiss, and M. E. Barber. 2003. Predicting fish passage design flows at ungaged streams in eastern Washington. J ournal of Hydrology 273 (14):177-187. http:// dx.doi.org/ 10.1016/ S0022-1694(02)00391-8 
Saunders, S. C., M. R. Mislivets, J . Chen, and D. T. Cleland. 2002. Effects of roads on landscape structure within nested ecological units of the Northern Great Lakes Region, USA. Biological Conservation 103 (2):209-225. http: // www.sciencedirect.com/ science/ article/ B6V5X-44MX6S2B/ 2/ 042d549a871e32258aad5ec74adb8918

Smith, D. J., ed. 2003. Ecological effects of roads: Theory, analysis, management and planning considerations. University of Florida.

Snead, S. 2005. Route 17 - The four decade project. Public Roads 68 (6):28-34.

Stickney, M. 2008. Building bridges, fording streams, reaching agreement in the Lake Champlain basin: Alternatives to legislation and regulation rooted in citizen and science-based approaches to inspire watershed protection. Water SA 34 (4 SPEC. ISS.):468-475.

Stringer, J ., and A. Thompson. 2001. Comparison of forestry best management practices. Part II: Forest roads and skid trails. Forest Landowner 60 (2):39-44.

Svobodova, J ., M. Salek, and T. Albrecht. 2007. Roads do not increase predation on experimental nests in a highly fragmented forest landscape. Folia Zoologica 56 (1):84-89.

Thompson, A. M., K. Kim, and A. J . Vandermuss. 2008. Thermal characteristics of stormwater runoff from asphalt and sod surfaces. J ournal of the American Water Resources Association 44 (5):1325-1336. http:// dx.doi.org/ 10.1111/j.17521688.2008.00226.x

Trombulak, S. C., and C. A. Frissell. 2000. Review of ecological effects of roads on terrestrial and aquatic communities. Conservation Biology 14 (1):18-30. http://www.jstor.org/ stable/ 2641900

Wang, C., N.-B. Chang, and G.-T. Yeh. 2009. Copula-based flood frequency (COFF) analysis at the confluences of river systems. Hydrological Processes 23 (10):14711486. http:// dx.doi.org/ 10.1002/ hyp.7273

Wargo, R. S., and R. N. Weisman. 2006. A comparison of single-cell and multicell culverts for stream crossings. J ournal of the American Water Resources Association 42 (4):989-995. http:/ / dx.doi.org/ 10.1111/j.17521688.2006.tb04509.x

Washington State Department of Transportation (WSDOT). 2008. Wetland and buffer impact assessment guidance. Washington State Department of Transportation http:/ / www.wsdot.wa.gov/NR/ rdonlyres/D0FE60A8-A193-4615-A68427E66CFBFB61/ 0/ WetMitBuffImpAssess.pdf.

Wemple, B. C., and J . A. J ones. 2003. Runoff production on forest roads in a steep, mountain catchment. Water Resources Research 39 (8):SWC81-SWC817. http:/ / dx.doi.org/ 10.1029/ 2002WR001744

Wemple, B. C., F. J . Swanson, and J . A. Jones. 2001. Forest roads and geomorphic process interactions, Cascade Range, Oregon. Earth Surface Processes and Landforms 26 (2):191-204. http:// dx.doi.org/ 10.1002/ 10969837(200102)26:2<191: :AID-ESP175>3.0.CO;2-U 
Whited, D., S. Galatowitsch, J . R. Tester, K. Schik, R. Lehtinen, and J . Husveth. 2000. Importance of local and regional factors in predicting effective conservation planning strategies for wetland bird communities in agricultural and urban landscapes. Landscape and Urban Planning (Amsterdam) 49 (1-2):49-65. http: / dx.doi.org/ 10.1016/ S0169-2046(00)00046-3

Zech, W. C., J. L. Halverson, and T. P. Clement. 2008. Intermediate-scale experiments to evaluate silt fence designs to control sediment discharge from highway construction sites. J ournal of Hydrologic Engineering 13 (6):497-504. http:// dx.doi.org/ 10.1061/ (ASCE)1084-0699(2008)13: 6(497) 


\section{Appendix 0: Roads and Wildlife}

Ament, R., A. Clevenger, O. Yu, and A. Hardy. 2008. An assessment of road impacts on wildlife populations in U.S. National Parks. Environmental Management 42 (3):480-496. http:// dx.doi.org/ 10.1007/s00267-008-9112-8

Andrews, K. M., and J . W. Gibbons. 2005. How do highways influence snake movement? Behavioral responses to roads and vehicles. Copeia (4):772-782.

Antworth, R. L., D. A. Pike, and E. E. Stevens. 2005. Hit and run: Effects of scavenging on estimates of roadkilled vertebrates. Southeastern Naturalist 4 (4):647-656.

Aresco, M. J . 2005. Mitigation measures to reduce highway mortality of turtles and other herpetofauna at a north Florida lake. J ournal of Wildlife Management 69 (2):549-560.

Avila-Flores, R., and M. B. Fenton. 2005. Use of spatial features by foraging insectivorous bats in a large urban landscape. J ournal of Mammalogy 86 (6):1193-1204.

Baldwin, E. A., M. N. Marchand, and J . A. Litvaitis. 2004. Terrestrial habitat use by nesting painted turtles in landscapes with different levels of fragmentation. Northeastern Naturalist 11(1):41-48.

Brack, V. 2006. Autumn activity of Myotis sodalis (Indiana bat) in Bland County, Virginia. Northeastern Naturalist 13 (3):421-434.

Braden, A. W., R. R. Lopez, C. W. Roberts, N. J . Silvy, C. B. Owen, and P. A. Frank. 2008. Florida Key deer Odocoileus Virginianus Clavium underpass use and movements along a highway corridor. Wildlife Biology 14 (1):155-163.

Broders, H. G., G. J . Forbes, S. Woodley, and I. D. Thompson. 2006. Range extent and stand selection for roosting and foraging in forest-dwelling northern long-eared bats and little brown bats in the Greater Fundy Ecosystem, New Brunswick. J ournal of Wildlife Management 70 (5):1174-1184.

Chambers, D. L. 2008. Logging road effects on breeding-site selection in Notophthalmus viridescens (Red-spotted Newt) and three ambystomatid salamanders in southcentral Pennsylvania. Northeastern Naturalist 15 (1):123-130.

Demaynadier, P. G., and M. L. Hunter. 2000. Road effects on amphibian movements in a forested landscape. Natural Areas J ournal 20 (1):56-65.

Elmore, L. W., D. A. Miller, and F. J . Vilella. 2005. Foraging area size and habitat use by red bats (Lasiurus borealis) in an intensively managed pine landscape in Mississippi. American Midland Naturalist 153 (2):405-417.

Gaisler, J ., Z. Rehak, and T. Bartonicka. 2009. Bat casualties by road traffic (BrnoVienna). Acta Theriologica 54 (2):147-155. 
Gibbs, J . P. 1998. Amphibian movements in response to forest edges, roads, and streambeds in Southern New England. J ournal of Wildlife Management 62 (2):584-589.

Hein, C. D., K. V. Miller, and S. B. Castleberry. 2009. Evening bat summer roost-site selection on a managed pine landscape. J ournal of Wildlife Management 73 (4):511-517.

Henderson, L. E., and H. G. Broders. 2008. Movements and resource selection of the northern long-eared myotis (Myotis septentrionalis) in a forest-agriculture landscape. J ournal of Mammalogy 89 (4):952-963.

J ackson, S. D. 2000. Overview of transportation impacts on wildlife movement and populations. In Wildlife and highways: Seeking solutions to an ecological and socio-economic dilemma. The Wildlife Society.

Karraker, N. E., J . P. Gibbs, and J . R. Vonesh. 2008. Impacts of road deicing salt on the demography of vernal pool-breeding amphibians. Ecological Applications 18 (3):724-734.

Kerth, G., and M. Melber. 2009. Species-specific barrier effects of a motorway on the habitat use of two threatened forest-living bat species. Biological Conservation $142(2): 270-279$.

http:// www.sciencedirect.com/science?_ob=MImg\&_imagekey=B6V5X4V2G7KB-5-

$7 \& \_$cdi $=5798 \&$ user $=930810 \&$ \& orig $=$ search\&_coverDate $=02 \% 2 F 28 \% 2 F 2009$ \& $\overline{s k}=998579997 \& v i e w=c \& w c h p=d G L z V t b-$ zŚSkV\&md5=c0a8f0182416f1d0b34eaa573a7e97af\&ie=/ sdarticle.pdf

Klatt, B. J ., and L. L. Getz. 1987. Vegetation characteristics of Microtus ochrogaster and M. pennsylvanicus habitats in east-central Illinois. J ournal of Mammalogy 68 (3):569-577. http:// www.jstor.org/ stable/ 1381593

Kunz, T. H., E. B. Arnett, B. M. Cooper, W. P. Erickson, R. P. Larkin, T. Mabee, M. L. Morrison, M. D. Strickland, and J . M. Szewczak. 2007. Assessing impacts of wind-energy development on nocturnally active birds and bats: A guidance document. J ournal of Wildlife Management 71 (8):2449-2486.

Kuvlesky, W. P., L. A. Brennan, M. L. Morrison, K. K. Boydston, B. M. Ballard, and F. C. Bryant. 2007. Wind energy development and wildlife conservation: Challenges and opportunities. J ournal of Wildlife Management 71 (8):2487-2498.

Langen, T. A., A. Machniak, E. K. Crowe, C. Mangan, D. F. Marker, N. Liddle, and B. Roden. 2007. Methodologies for surveying herpetofauna mortality on rural highways. J ournal of Wildlife Management 71 (4):1361-1368.

Langen, T. A., K. M. Ogden, and L. L. Schwarting. 2009. Predicting hot spots of herpetofauna road mortality along highway networks. J ournal of Wildlife Management 73 (1):104-114.

Laurian, C., C. Dussault, J . P. Ouellet, R. Courtois, M. Poulin, and L. Breton. 2008. Behavior of moose relative to a road network. J ournal of Wildlife Management 72 (7):1550-1557. 
Lesinski, G. 2007. Bat road casualties and factors determining their number. Mammalia 71(3):138-142.

- 2008. Linear landscape elements and bat casualties on roads - an example. Annales Zoologici Fennici 45 (4):277-280.

Limpert, D. L., D. L. Birch, M. S. Scott, M. Andre, and E. Gillam. 2007. Tree selection and landscape analysis of eastern red bat day roosts. J ournal of Wildlife Management 71 (2):478-486.

Loeb, S. C., and J . M. O'Keefe. 2006. Habitat use by forest bats in South Carolina in relation to local, stand, and landscape characteristics. J ournal of Wildlife Management 70 (5):1210-1218.

Marsh, D. M. 2007. Edge effects of gated and ungated roads on terrestrial salamanders. J ournal of Wildlife Management 71 (2):389-394.

Marsh, D. M., and N. G. Beckman. 2004. Effects of forest roads on the abundance and activity of terrestrial salamanders. Ecological Applications 14 (6):1882-1891.

Marsh, D. M., G. S. Milam, N. R. Gorham, and N. G. Beckman. 2005. Forest roads as partial barriers to terrestrial salamander movement. Conservation Biology 19 (6):2004-2008.

Mazerolle, M. J . 2004. Amphibian road mortality in response to nightly variations in traffic intensity. Herpetologica 60 (1):45-53.

McCown, J . W., P. Kubilis, T. H. Eason, and B. K. Scheick. 2009. Effect of traffic volume on American black bears in central Florida, USA. Ursus 20 (1):39-46.

Ober, H. K., and J . P. Hayes. 2008. Influence of vegetation on bat use of riparian areas at multiple spatial scales. J ournal of Wildlife Management 72 (2):396-404.

Owen, S. F., M. A. Menzel, W. M. Ford, B. R. Chapman, K. V. Miller, J. W. Edwards, and P. B. Wood. 2003. Home-range size and habitat used by the northern myotis (Myotis septentrionalis). American Midland Naturalist 150 (2):352-359.

Perry, R. W. 2007. Summer roosting by adult male seminole bats in the Ouachita Mountains, Arkansas. American Midland Naturalist 158 (2):361-368.

Perry, R. W., R. E. Thill, and D. M. Leslie. 2008. Scale-dependent effects of landscape structure and composition on diurnal roost selection by forest bats. J ournal of Wildlife Management 72 (4):913-925.

Reynolds, D. S. 2006. Monitoring the potential impact of a wind development site on bats in the northeast. J ournal of Wildlife Management 70 (5):1219-1227.

Reynolds-Hogland, M. J., and M. S. Mitchell. 2007. Effects of roads on habitat quality for bears in the southern Appalachians: A long-term study. J ournal of Mammalogy 88 (4):1050-1061.

Rico, A., P. Kindlmann, and F. Sedlacek. 2007. Barrier effects of roads on movements of small mammals. Folia Zoologica 56 (1):1-12. 
Roe, J . H., B. A. Kingsbury, and N. R. Herbert. 2003. Wetland and upland use patterns in semi-aquatic snakes: Implications for wetland conservation. Wetlands 23 (4):1003-1014. http:// dx.doi.org/ 10.1672/ 02775212(2003)023[1003:WAUUPI]2.0.CO; 2

Roe, J . H., J . Gibson, and B. A. Kingsbury. 2006. Beyond the wetland border: Estimating the impact of roads for two species of water snakes. Biological Conservation 130 (2):161-168.

http://www.sciencedirect.com/science?_ob=MImg\&_imagekey=B6V5X-

4J 2TSR8-2-

$9 \& \_$cdi $=5798 \&$ _ user $=930810 \&$ \& orig $=$ search\&_coverDate $=06 \% 2 \mathrm{~F} 30 \% 2 \mathrm{~F} 2006$

\& sk=998699997\&view $=c \& w c h p=d G L z V z z-$

zSkkWb\&md5=078fa0cfbbf6b8b1f66457876c977f46\&ie=/ sdarticle.pdf

Row, J . R., G. Blouin-Demers, and P. J . Weatherhead. 2007. Demographic effects of road mortality in black ratsnakes (Elaphe Obsoleta). Biological Conservation 137

(1):117-124.

http:// www.sciencedirect.com/science?_ob=MImg\&_imagekey=B6V5X-

4NCKKOY-1-

9\&_ cdi $=5798 \&$ user $=930810 \&$ orig $=$ search\&_ coverDate $=06 \% 2 \mathrm{~F} 30 \% 2 \mathrm{~F} 2007$ \& $\bar{s} k=998629998 \& v i e w=c \& w c h p=d G L b V z b-$ zSkWb\&md5=bf539d121ff69f83ea2b014db08ccb12\&ie=/ sdarticle.pdf

Rowland, M. M., M. J . Wisdom, B. K. J ohnson, and J . G. Kie. 2000. Elk distribution and modeling in relation to roads. J ournal of Wildlife Management 64 (3):672-684.

Schaub, A., J . Ostwald, and B. M. Siemers. 2008. Foraging bats avoid noise. J ournal of Experimental Biology 211 (19):3174-3180.

Schindler, D. W. 2000. Aquatic problems caused by human activities in Banff National Park, Alberta, Canada. Ambio 29 (7):401-407.

Semlitsch, R. D., T. J . Ryan, K. Ramed, M. Chatfield, B. Drehman, N. Pekarek, M. Spath, and A. Watland. 2007. Salamander abundance along road edges and within abandoned logging roads in Appalachian forests. Conservation Biology $21(1): 159-167$.

Shepard, D. B., M. J . Dreslik, B. C. J ellen, and C. A. Phillips. 2008. Reptile road mortality around an oasis in the Illinois Corn Desert with emphasis on the endangered Eastern Massasauga. Copeia (2):350-359.

Shine, R., M. Lemaster, M. Wall, T. Langkilde, and R. Mason. 2004. Why did the snake cross the road? Effects of roads on movement and location of mates by garter snakes (Thamnophis Sirtalis Parietalis) - Art. No. 9. Ecology and Society 9 (1):9.

Sparks, D. W., C. M. Ritzi, J . E. Duchamp, and J . O. Whitaker. 2005. Foraging habitat of the Indiana bat (Myotis sodalis) at an urban-rural interface. J ournal of Mammalogy 86 (4):713-718.

Steen, D. A., M. J . Aresco, S. G. Beilke, B. W. Compton, E. P. Condon, C. K. Dodd, H. Forrester, J . W. Gibbons, J . L. Greene, G. J ohnson, T. A. Langen, M. J . Oldham, D. N. Oxier, R. A. Saumure, F. W. Schueler, J . M. Sleeman, L. L. Smith, J . K. Tucker, and J . P. Gibbs. 2006. Relative vulnerability of female turtles to road mortality. Animal Conservation 9 (3):269-273. 
Timm, B. C., K. McGarigal, and L. R. Gamble. 2007. Emigration timing of juvenile pondbreeding amphibians in western Massachusetts. J ournal of Herpetology $41(2): 243-250$.

Ward, R. L., J . T. Anderson, and J . T. Petty. 2008. Effects of road crossings on stream and streamside salamanders. J ournal of Wildlife Management 72 (3):760-771.

Woltz, H. W., J . P. Gibbs, and P. K. Ducey. 2008. Road crossing structures for amphibians and reptiles: Informing design through behavioral analysis. Biological Conservation 141(11):2745-2750.

Yost, A. C., and R. G. Wright. 2001. Moose, caribou, and grizzly bear distribution in relation to road traffic in Denali National Park, Alaska. Arctic 54 (1):41-48. 


\section{Appendix P: Silviculture}

Beschta, R. L., M. R. Pyles, A. E. Skaugset, and C. G. Surfleet. 2000. Peakflow responses to forest practices in the western cascades of Oregon, USA.J ournal of Hydrology 233 (1-4):102-120. http:// dx.doi.org/ 10.1016/ S0022-1694(00)00231-6

Bockheim, J . G., H. Park, and J . Gallagher. 2005. Genotypic variation and recovery of Populus tremuloides from biomass removal and compaction in northern Wisconsin, USA. Canadian J ournal of Forest Research 35 (1):221-228. http:// dx.doi.org/ 10.1139/x04-147

Bowen, L. T., C. E. Moorman, and J . C. Kilgo. 2007. Seasonal bird use of canopy gaps in a bottomland forest. Wilson J ournal of Ornithology 119 (1):77-88.

Buckley, D. S., T. R. Crow, E. A. Nauertz, and K. E. Schulz. 2003. Influence of skid trails and haul roads on understory plant richness and composition in managed forest landscapes in Upper Michigan, USA. Forest Ecology and Management 175 (1-3):509-520. http:// dx.doi.org/ 10.1016/ S0378-1127(02)00185-8

Dun, S., J . Q. Wu, W. J . Elliot, P. R. Robichaud, D. C. Flanagan, J . R. Frankenberger, R. E. Brown, and A. C. Xu. 2009. Adapting the water erosion prediction project (WEPP) model for forest applications. J ournal of Hydrology 366 (1-4):46-54. http:// dx.doi.org/ 10.1016/j.jhydrol.2008.12.019

Flaspohler, D. J ., C. J . F. Huckins, B. R. Bub, and P. J . Van Dusen. 2002. Temporal patterns in aquatic and avian communities following selective logging in the Upper Great Lakes Region. Forest Science 48 (2):339-349.

Goldstein, M. I., R. N. Wilkins, and T. E. Lacher. 2005. Spatiotemporal responses of reptiles and amphibians to timber harvest treatments. J ournal of Wildlife Management 69 (2):525-539.

Goldstein, M. I., R. N. Wilkins, T. E. Lacher, And Russell. 2005. Spatiotemporal responses of reptiles and amphibians to timber harvest treatments. J ournal of Wildlife Management 69 (2):525-539. http:// dx.doi.org/ 10.2193/ 0022541X(2005)069[0525:SRORAA]2.0.CO; 2

Gravelle, J . A., and T. E. Link. 2007. Influence of timber harvesting on headwater peak stream temperatures in a northern Idaho Watershed. Forest Science 53 (2):189205.

Hanowski, J., N. Danz, and J . Lind. 2007. Breeding bird response to riparian forest management: 9 years post-harvest. Forest Ecology and Management 241 (1-3):272-277.

http:// www.sciencedirect.com/science?_ob=ArticleURL\&_udi=B6T6X$4 \mathrm{~N} 2 \mathrm{D} 60 \mathrm{~K}-$

3\&_user $=930810 \& \_r d o c=1 \&$ fmt $=\& \_$orig $=$search\&_sort=d\&_docanchor $=$\&vie $\mathrm{w}=\mathrm{c} \&$ _acct $=\mathrm{C} 000048423 \&$ version $=1 \&$ _ urlVersion $=0 \&$ userid $=930810 \& \mathrm{md} 5$ $=1123 \bar{a} 756 f 675 b e 2 e 1 e e d 7 a 7 \bar{d} f c 2 b 4 b c 4$ 
Hanowski, J ., N. Danz, J . Lind, and G. Niemi. 2003. Breeding bird response to riparian forest harvest and harvest equipment. Forest Ecology and Management 174 (1-3):315-328. http:/ / dx.doi.org/ 10.1016/ S0378-1127(02)00040-3

Harrison, C. A., and J . C. Kilgo. 2004. Short-term breeding bird response to two harvest practices in a bottomland hardwood forest. Wilson Bulletin 116 (4):314-323.

Heltzel, J . M., and P. L. Leberg. 2006. Effects of selective logging on breeding bird communities in bottomland hardwood forests in Louisiana. J ournal of Wildlife Management 70 (5):1416-1424.

Hubbart, J . A., T. E. Link, J . A. Gravelle, and W. J . Elliot. 2007. Timber harvest impacts on water yield in the continental/ maritime hydroclimatic region of the United States. Forest Science 53 (2):169-180.

Hutchens, J .J ., D. P. Batzer, and E. Reese. 2004. Bioassessment of silvicultural impacts in streams and wetlands of the Eastern United States. Water, Air, \& Soil Pollution: Focus 4 (1):37-53. http:// dx.doi.org/ 10.1023/ B:WAFO.0000012827.95431.b8

J ackson, C. R., D. P. Batzer, S. S. Cross, S. M. Haggerty, and C. A. Sturm. 2007. Headwater streams and timber harvest, channel, macroinvertebrate, and amphibian response and recovery. Forest Science 53 (2):356-370.

Kardynal, K. J ., K. A. Hobson, S. L. Van Wilgenburg, and J . L. Morissette. 2009. Moving riparian management guidelines towards a natural disturbance model: An example using boreal riparian and shoreline forest bird communities. Forest Ecology and Management 257 (1):54-65.

http:// www.sciencedirect.com/science?_ob=ArticleURL\&_udi=B6T6X4TMHKTX-

$1 \& \_$user $=930810 \& \_$rdoc $=1 \&$ fmt $=\& \_$orig $=$search\&_sort=d\&_docanchor $=$\&vie $\mathrm{w}=\mathrm{c} \&$ acct $=\mathrm{C} 000048423 \&$ version $=11_{\_}$urlVersion $=0 \&$ _ userid $=930810 \& \mathrm{md} 5$ $=$ bed0f4ebf0a4ee28b75f416f9bec26c4

Karwan, D. L., J . A. Gravelle, and J . A. Hubbart. 2007. Effects of timber harvest on suspended sediment loads in Mica Creek, Idaho. Forest Science 53 (2):181-188.

Kilgo, J . C. 2005. Harvest-related edge effects on prey availability and foraging of hooded warblers in a bottomland hardwood forest. Condor 107 (3):627-636.

Kilgo, J . C., K. V. Miller, and W. P. Smith. 1999. Effects of group-selection timber harvest in bottomland hardwoods on fall migrant birds. J ournal of Field Ornithology 70 (3):404-413. http:// www.blackwellpublishing.com

Kittredge, D. B., K. Clark, M. Ohmann, P. Huckery, and T. French. 2006. Protection of habitat for state-listed rare flora and fauna in Massachusetts during timber harvesting. Natural Areas J ournal 26 (2):198-207.

La Marche, J . L., and D. P. Lettenmaier. 2001. Effects of forest roads on flood flows in the Deschutes River, Washington. Earth Surface Processes and Landforms 26 (2):115-134. http:// dx.doi.org/ 10.1002/ 1096-9837(200102)26: 2<115: :AIDESP166>3.0.CO;2-O 
Litvaitis, J . A. 2001. Importance of early successional habitats to mammals in eastern forests. Wildlife Society Bulletin 29 (2):466-473. http://www.jstor.org/ stable/ 3784170

Litvaitis, J . A., and R. Villafuerte. 1996. Factors affecting the persistence of new england cottontail metapopulations: The role of habitat management. Wildlife Society Bulletin 24 (4):686-693. http:/ / www.jstor.org/ stable/ 3783159

Loehle, C., T. B. Wigley, S. Rutzmoser, J . A. Gerwin, P. D. Keyser, R. A. Lancia, C. J . Reynolds, R. E. Thill, R. Weih, D. White J r., and P. B. Wood. 2005. Managed forest landscape structure and avian species richness in the southeastern US. Forest Ecology and Management 214 (1-3):279-293.

Manolis, J . C., D. E. Andersen, and F. J . Cuthbert. 2002. Edge effect on nesting success of ground nesting birds near regenerating clearcuts in a forest-dominated landscape. Auk 119 (4):955-970.

McCord, S. B., R. S. Grippo, and D. M. Eagle. 2007. Effects of silviculture using best management practices on stream macroinvertebrate communities in three ecoregions of Arkansas, USA. Water, Air, and Soil Pollution 184 (1-4):299-311. http:// dx.doi.org/ 10.1007/ s11270-007-9417-x

McLaughlin, J. W., M. R. Gale, M. F. J urgensen, and C. C. Trettin. 2000. Soil organic matter and nitrogen cycling in response to harvesting, mechanical site preparation, and fertilization in a wetland with a mineral substrate. Forest Ecology and Management 129 (1):7-23. http:// dx.doi.org/ 10.1016/ S03781127(99)00164-4

National Council for Air and Stream Improvement, Inc. (NCASI). 2009. Wildlife responses to stand-level structural retention practices in the boreal forest. Research Triangle Park, NC.

Pierre, J . P., S. M. Boss, and C. A. Paszkowski. 2005. Effects of forest harvesting on Bufflehead and Common Loon foraging behavior. Ornithological Science 4 (2):161-168.

Pollock, M. M., T. J . Beechie, M. Liermann, and R. E. Bigley. 2009. Stream temperature relationships to forest harvest in Western Washington. J ournal of the American Water Resources Association 45 (1):141-156. http:// dx.doi.org/ 10.1111/j.17521688.2008.00266.x

Rashin, E. B., C. J . Clishe, A. T. Loch, and J . M. Bell. 2006. Effectiveness of timber harvest practices for controlling sediment related water quality impacts. J ournal of the American Water Resources Association 42 (5):1307-1327.

Semlitsch, R. D., C. A. Conner, D. J . Hocking, T. A. G. Rittenhouse, and E. B. Harper. 2008. Effects of timber harvesting on pond-breeding amphibian persistence: Testing the evacuation hypothesis. Ecological Applications 18 (2):283-289.

Teply, M., D. McGreer, D. Schult, and P. Seymour. 2007. Simulating the effects of forest management on large woody debris in streams in northern Idaho. Western J ournal of Applied Forestry 22 (2):81-87. 
Tonina, D., C. H. Luce, B. Rieman, J . M. Buffington, P. Goodwin, S. R. Clayton, S. M. Ali, J. J . Barry, and C. Berenbrock. 2008. Hydrological response to timber harvest in northern Idaho: Implications for channel scour and persistence of salmonids. Hydrological Processes 22 (17):3223-3235. http:/ / dx.doi.org/ 10.1002/ hyp.6918

Wang, X., D. A. Burns, R. D. Yanai, R. D. Briggs, and R. H. Germain. 2006. Changes in stream chemistry and nutrient export following a partial harvest in the Catskill Mountains, New York, USA. Forest Ecology and Management 223 (1-3):103-112. http:// dx.doi.org/ 10.1016/j.foreco.2005.10.060

Williams, L. R., C. M. Taylor, M. L. Warren Jr, and J . A. Clingenpeel. 2002. Large-scale effects of timber harvesting on stream systems in the Ouachita Mountains, Arkansas, USA. Environmental Management 29 (1):76-87. http://dx.doi.org/ 10.1007/ s00267-001-0042-y 


\section{Appendix Q: Stream Channel Geometry and Stability}

Abad, J. D., and M. H. Garcia. 2006. RVR Meander: A toolbox for re-meandering of channelized streams. Computers and Geosciences 32 (1):92-101. http:// dx.doi.org/ 10.1016/j.cageo.2005.05.006

Agouridis, C. T., D. R. Edwards, S. R. Workman, J . R. Bicudo, B. K. Koostra, E. S. Vanzant, and J. L. Taraba. 2005. Streambank erosion associated with grazing practices in the humid region. Transactions of the American Society of Agricultural Engineers 48 (1):181-190.

Allan, C. J ., and C. J . Estes. 2005. A morphological and economic examination of plunge pools as energy dissipaters in urban stream channels. J ournal of the American Water Resources Association 41(1):123-133.

Allen, P. M., J . G. Arnold, and W. Shipwith. 2008. Prediction of channel degradation rates in urbanizing watersheds. Hydrological Sciences J ournal 53 (5):1013-1029. http:/ / dx.doi.org/ 10.1623/ hysj.53.5.1013

Ames, D. P., E. B. Rafn, R. Van Kirk, and B. Crosby. 2009. Estimation of stream channel geometry in Idaho using GIS-derived watershed characteristics. Environmental Modelling and Software 24 (3):444-448. http:/ / dx.doi.org/ 10.1016/j.envsoft.2008.08.008

Anderson, R. J ., B. P. Bledsoe, and W. C. Hession. 2004. Width of streams and rivers in response to vegetation, bank material, and other factors. J ournal of the American Water Resources Association 40 (5):1159-1172.

Anthony, D. M., and D. E. Granger. 2007. An empirical stream power formulation for knickpoint retreat in Appalachian Plateau fluviokarst. J ournal of Hydrology 343 (3-4):117-126. http:// dx.doi.org/ 10.1016/j.jhydrol.2007.06.013

Barry, J .J ., J . M. Buffington, and J . G. King. 2004. A general power equation for predicting bed load transport rates in gravel bed rivers. Water Resources Research 40 (10):W104011-W1040122. http:/ / dx.doi.org/ 10.1029/ 2004WR003190

Beechie, T. J ., M. M. Pollock, and S. Baker. 2008. Channel incision, evolution and potential recovery in the Walla Walla and Tucannon River basins, northwestern USA. Earth Surface Processes and Landforms 33 (5):784-800. http:/ / dx.doi.org/ 10.1002/ esp.1578

Benda, L., K. Andras, D. Miller, and P. Bigelow. 2004. Confluence effects in rivers: Interactions of basin scale, network geometry, and disturbance regimes. Water Resources Research 40 (5):W054021-W0540215. 
Bennett, S. J ., W. Wu, C. V. Alonso, and S. S. Y. Wang. 2008. Modeling fluvial response to in-stream woody vegetation: Implications for stream corridor restoration. Earth Surface Processes and Landforms 33 (6):890-909. http://dx.doi.org/ 10.1002/ esp.1581

Bledsoe, B. P., C. C. Watson, and D. S. Biedenharn. 2002. Quantification of incised channel evolution and equilibrium. J ournal of the American Water Resources Association 38 (3):861-870.

Brummer, C. J ., and D. R. Montgomery. 2006. Influence of coarse lag formation on the mechanics of sediment pulse dispersion in a mountain stream, Squire Creek, North Cascades, Washington, United States. Water Resources Research 42 (7). http:// dx.doi.org/ 10.1029/2005WR004776

Bukaveckas, P. A. 2007. Effects of channel restoration on water velocity, transient storage, and nutrient uptake in a channelized stream. Environmental Science and Technology 41 (5):1570-1576. http:// dx.doi.org/ 10.1021/ es061618x

Cardenas, M. B., J . L. Wilson, and V. A. Zlotnik. 2004. Impact of heterogeneity, bed forms, and stream curvature on subchannel hyporheic exchange. Water Resources Research 40 (8):W083071-W0830713. http:// dx.doi.org/ 10.1029/ 2004WR003008

Chatanantavet, P., and G. Parker. 2008. Experimental study of bedrock channel alluviation under varied sediment supply and hydraulic conditions. Water Resources Research 44 (12). http:/ / dx.doi.org/ 10.1029/ 2007WR006581

Chin, A., D. L. Harris, T. H. Trice, and J . L. Given. 2002. Adjustment of stream channel capacity following dam closure, Yegua Creek, Texas. J ournal of the American Water Resources Association 38 (6):1521-1531.

Chu-Agor, M. L., G. V. Wilson, and G. A. Fox. 2008. Numerical modeling of bank instability by seepage erosion undercutting of layered streambanks. J ournal of Hydrologic Engineering 13 (12):1133-1145. http:/ / dx.doi.org/ 10.1061/ (ASCE)1084-0699(2008)13: 12(1133)

Cianfrani, C. M., W. C. Hession, and D. M. Rizzo. 2006. Watershed imperviousness impacts on stream channel condition in southeastern Pennsylvania. J ournal of the American Water Resources Association 42 (4):941-956. http:/ / dx.doi.org/ 10.1111/j.1752-1688.2006.tb04506.x

Clark, L. A., and T. M. Wynn. 2007. Methods for determining streambank critical shear stress and soil erodibility: Implications for erosion rate predictions. Transactions of the ASABE 50 (1):95-106.

Clayton, J . A., and J . Pitlick. 2008. Persistence of the surface texture of a gravel-bed river during a large flood. Earth Surface Processes and Landforms 33 (5):661-673. http:// dx.doi.org/ 10.1002/ esp.1567

Colosimo, M. F., and P. R. Wilcock. 2007. Alluvial sedimentation and erosion in an urbanizing watershed, Gwynns Falls, Maryland. J ournal of the American Water Resources Association 43 (2):499-521. http:// dx.doi.org/ 10.1111/j.17521688.2007.00039.x 
Crispell, J. K., and T. A. Endreny. 2009. Hyporheic exchange flow around constructed inchannel structures and implications for restoration design. Hydrological Processes 23 (8):1158-1168. http:// dx.doi.org/ 10.1002/ hyp.7230

Daniels, M. D., and B. L. Rhoads. 2007. Influence of experimental removal of large woody debris on spatial patterns of three-dimensional flow in a meander bend. Earth Surface Processes and Landforms 32 (3):460-474. http:// dx.doi.org/ 10.1002/ esp.1419

Downs, P. W., and G. M. Kondolf. 2002. Post-project appraisals in adaptive management of river channel restoration. Environmental Management 29 (4):477-496. http:/ / dx.doi.org/ 10.1007/ s00267-001-0035-X

Doyle, M. W., D. Shields, K. F. Boyd, P. B. Skidmore, and D. Dominick. 2007. Channelforming discharge selection in river restoration design. J ournal of Hydraulic Engineering 133 (7):831-837. http:// dx.doi.org/ 10.1061/ (ASCE)07339429(2007)133: 7(831)

Doyle, M. W., E. H. Stanley, and J. M. Harbor. 2003. Channel adjustments following two dam removals in Wisconsin. Water Resources Research 39 (1):ESG21-ESG215. http:/ / dx.doi.org/ 10.1029/ 2002WR001714

Duan, J . G. 2005. Analytical approach to calculate rate of bank erosion. J ournal of Hydraulic Engineering 131(11):980-990. http:// dx.doi.org/ 10.1061/(ASCE)0733-9429(2005)131:11(980)

Elkins, E. M., G. B. Pasternack, and J. E. Merz. 2007. Use of slope creation for rehabilitating incised, regulated, gravel bed rivers. Water Resources Research 43 (5). http:// dx.doi.org/ 10.1029/ 2006WR005159

Fagherazzi, S., A. D. Howard, A. W. Niedoroda, and P. L. Wiberg. 2008. Controls on the degree of fluvial incision of continental shelves. Computers and Geosciences 34 (10):1381-1393. http:// dx.doi.org/ 10.1016/j.cageo.2008.02.004

Faucette, B., and M. Ruhlman. 2004. Stream bank stabilization utilizing compost. BioCycle 45 (1):27.

Fox, G. A., G. V. Wilson, A. Simon, E. J . Langendoen, O. Akay, and J . W. Fuchs. 2007. Measuring streambank erosion due to ground water seepage: Correlation to bank pore water pressure, precipitation and stream stage. Earth Surface Processes and Landforms 32 (10):1558-1573. http:// dx.doi.org/ 10.1002/ esp.1490

Fox, J . F., A. N. Papanicolaou, B. Hobbs, C. Kramer, and L. Kjos. 2005. Fluid-sediment dynamics around a barb: An experimental case study of a hydraulic structure for the Pacific Northwest. Canadian J ournal of Civil Engineering 32 (5):853-867. http:// dx.doi.org/ 10.1139/105-033

Gatz, A. J ., J r. 2008. The use of floating overhead cover by warmwater stream fishes. Hydrobiologia 600 (1):307-310. http:// dx.doi.org/ 10.1007/ s10750-007-9252-5

Grable, J . L., and C. P. Harden. 2006. Geomorphic response of an Appalachian Valley and Ridge stream to urbanization. Earth Surface Processes and Landforms 31 (13):1707-1720. http:// dx.doi.org/ 10.1002/ esp.1433 
Grace, J . M., III. 2002. Control of sediment export from the forest road prism. Transactions of the American Society of Agricultural Engineers 45 (4):11271132.

Graf, W. L. 2000. Locational probability for a dammed, urbanizing stream: Salt River, Arizona, USA. Environmental Management 25 (3):321-335. http:// dx.doi.org/ 10.1007/ s002679910025

Grams, P. E., J . C. Schmidt, and D. J . Topping. 2007. The rate and pattern of bed incision and bank adjustment on the Colorado River in Glen Canyon downstream from Glen Canyon Dam, 1956-2000. Bulletin of the Geological Society of America 119 (5-6):556-575. http:// dx.doi.org/ 10.1130/B25969.1

Gran, K., and C. Paola. 2001. Riparian vegetation controls on braided stream dynamics. Water Resources Research 37 (12):3275-3283. http:/ / dx.doi.org/ 10.1029/ 2000WR000203

Gran, K. B., D. R. Montgomery, and D. G. Sutherland. 2006. Channel bed evolution and sediment transport under declining sand inputs. Water Resources Research 42 (10). http:/ / dx.doi.org/ 10.1029/2005WR004306

Hagen, S., S. Salisbury, M. Wierenga, G. Xu, and L. Lewis. 2002. Soil bioengineering as an alternative for roadside management: Benefit-cost analysis case study. Transportation Research Record (1794):97-104.

Hassan, M. A., R. Egozi, and G. Parker. 2006. Experiments on the effect of hydrograph characteristics on vertical grain sorting in gravel bed rivers. Water Resources Research 42 (9). http:/ / dx.doi.org/ 10.1029/ 2005WR004707

Hession, W. C., J . E. Pizzuto, T. E. J ohnson, and R. J . Horwitz. 2003. Influence of bank vegetation on channel morphology in rural and urban watersheds. Geology 31 (2):147-150.

Hicks, N. S., J . A. Smith, A. J . Miller, and P. A. Nelson. 2005. Catastrophic flooding from an orographic thunderstorm in the central Appalachians. Water Resources Research 41(12):1-17. http:// dx.doi.org/ 10.1029/2005WR004129

Hrodey, P. J ., B. J . Kalb, and T. M. Sutton. 2008. Macroinvertebrate community response to large-woody debris additions in small warmwater streams. Hydrobiologia 605 (1):193-207. http:// dx.doi.org/ 10.1007/ s10750-008-9354-8

J acobsen, S. M., and S. Becker. 2004. A soil bioengineering success: Elm Creek stream bank stabilization. Resource: Engineering and Technology for Sustainable World 11(9):9-10.

J ames, L. A. 2006. Bed waves at the basin scale: Implications for river management and restoration. Earth Surface Processes and Landforms 31 (13):1692-1706. http:// dx.doi.org/ 10.1002/ esp.1432

Kassem, A., and M. H. Chaudhry. 2005. Effect of bed armoring on bed topography of channel bends. J ournal of Hydraulic Engineering 131 (12):1136-1140. http:// dx.doi.org/ 10.1061/(ASCE)0733-9429(2005)131: 12(1136) 
Kaufmann, P. R., D. P. Larsen, and J . M. Faustini. 2009. Bed stability and sedimentation associated with human disturbances in Pacific Northwest streams. J ournal of the American Water Resources Association 45 (2):434-459. http:// dx.doi.org/ 10.1111/j.1752-1688.2009.00301.x

Kavage Adams, R., and J . A. Spotila. 2005. The form and function of headwater streams based on field and modeling investigations in the Southern Appalachian Mountains. Earth Surface Processes and Landforms 30 (12):1521-1546. http:/ / dx.doi.org/ 10.1002/ esp.1211

Klingbeil, A. D., and C. K. Sommerfield. 2005. Latest Holocene evolution and human disturbance of a channel segment in the Hudson River Estuary. Marine Geology 218 (1-4):135-153. http:/ / dx.doi.org/ 10.1016/j.margeo.2005.02.026

Knust, A. E., and J . J . Warwick. 2009. Using a fluctuating tracer to estimate hyporheic exchange in restored and unrestored reaches of the Truckee River, Nevada, USA. Hydrological Processes 23 (8):1119-1130. http:/ / dx.doi.org/ 10.1002/ hyp.7218

Kondolf, G. M., M. W. Smeltzer, and S. F. Railsback. 2001. Design and performance of a channel reconstruction project in a coastal California gravel-bed stream. Environmental Management 28 (6):761-776. http:/ / dx.doi.org/ 10.1007/ s002670010260

Lamb, M. P., J. D. Parsons, B. L. Mullenbach, D. P. Finlayson, D. L. Orange, and C. A. Nittrouer. 2008. Evidence for superelevation, channel incision, and formation of cyclic steps by turbidity currents in Eel Canyon, California. Bulletin of the Geological Society of America 120 (3-4):463-475. http:// dx.doi.org/ 10.1130/ B26184.1

Larsen, E. W., A. K. Fremier, and S. E. Greco. 2006. Cumulative effective stream power and bank erosion on the Sacramento River, California, USA. J ournal of the American Water Resources Association 42 (4):1077-1097. http:/ / dx.doi.org/ 10.1111/j.1752-1688.2006.tb04515.x

Larsen, E. W., and S. E. Greco. 2002. Modeling channel management impacts on river migration: A case study of Woodson Bridge State Recreation Area, Sacramento River, California, USA. Environmental Management 30 (2):209-224. http:/ / dx.doi.org/ 10.1007/ s00267-002-2663-1

Larsen, E. W., E. H. Girvetz, and A. K. Fremier. 2007. Landscape level planning in alluvial riparian floodplain ecosystems: Using geomorphic modeling to avoid conflicts between human infrastructure and habitat conservation. Landscape and Urban Planning 79 (3-4):338-346. http:// dx.doi.org/ 10.1016/j.landurbplan.2006.04.003

LaSage, D. M., J . L. Sexton, A. Mukherjee, A. E. Fryar, and S. F. Greb. 2008. Groundwater discharge along a channelized Coastal Plain stream. J ournal of Hydrology 360 (1-4):252-264. http:// dx.doi.org/10.1016/j.jhydrol.2008.06.026

Laser, M., J . J ordan, and K. Nislow. 2009. Riparian forest and instream large wood characteristics, West Branch Sheepscot River, Maine, USA. Forest Ecology and Management 257 (7):1558-1565. http:/ / dx.doi.org/ 10.1016/j.foreco.2008.12.024 
Lauer, J. W., and G. Parker. 2008. Modeling framework for sediment deposition, storage, and evacuation in the floodplain of a meandering river: Theory. Water Resources Research 44 (4). http:// dx.doi.org/ 10.1029/ 2006WR005528

Li, M.-H. 2006. Learning from streambank failures at bridge crossings: A biotechnical streambank stabilization project in warm regions. Landscape and Urban Planning 77 (4):343-358. http:// dx.doi.org/ 10.1016/j.landurbplan.2005.04.006

Li, M.-H., and K. E. Eddleman. 2002. Biotechnical engineering as an alternative to traditional engineering methods a biotechnical streambank stabilization design approach. Landscape and Urban Planning 60 (4):225-242. http:// dx.doi.org/ 10.1016/ S0169-2046(02)00057-9

Loheide, S. P., II, and S. M. Gorelick. 2007. Riparian hydroecology: A coupled model of the observed interactions between groundwater flow and meadow vegetation patterning. Water Resources Research 43 (7). http:/ / dx.doi.org/ 10.1029/ 2006WR005233

Maloney, K. O., P. J . Mulholland, and J . W. Feminella. 2005. Influence of catchmentscale military land use on stream physical and organic matter variables in small Southeastern Plains catchments (USA). Environmental Management 35 (5):677691. http:// dx.doi.org/ 10.1007/ s00267-004-4212-6

Marion, A., A. I. Packman, M. Zaramella, and A. Bottacin-Busolin. 2008. Hyporheic flows in stratified beds. Water Resources Research 44 (9). http:// dx.doi.org/ 10.1029/2007WR006079

Mattocks, C., and C. Forbes. 2008. A real-time, event-triggered storm surge forecasting system for the state of North Carolina. Ocean Modelling 25 (3-4):95-119. http:// dx.doi.org/ 10.1016/j.ocemod.2008.06.008

Maxwell, A. R., and A. N. Papanicolaou. 2001. Step-pool morphology in high-gradient streams. International J ournal of Sediment Research 16 (3):380-390.

May, C. 2007. Sediment and wood routing in steep headwater streams: An overview of geomorphic processes and their topographic signatures. Forest Science $53(2): 119-130$.

Murray, B. A., and C. Paola. 2003. Modelling the effect of vegetation on channel pattern in bedload rivers. Earth Surface Processes and Landforms 28 (2):131-143. http:// dx.doi.org/ 10.1002/ esp.428

Nelson, P. A., J . A. Smith, and A. J . Miller. 2006. Evolution of channel morphology and hydrologic response in an urbanizing drainage basin. Earth Surface Processes and Landforms 31 (9):1063-1079. http:// dx.doi.org/ 10.1002/ esp.1308

Nicklow, J. W., O. Ozkurt, and J . A. Bringer J r. 2003. Control of channel bed morphology in large-scale river networks using a genetic algorithm. Water Resources Management 17 (2):113-132. http:/ / dx.doi.org/ 10.1023/ A: 1023609806431 
Niezgoda, S. L., and P. A. J ohnson. 2005. Improving the urban stream restoration effort: Identifying critical form and processes relationships. Environmental Management 35 (5):579-592. http:/ / dx.doi.org/ 10.1007/ s00267-004-0088-8

- 2006. Modeling the long term impacts of using rigid structures in stream channel restoration. J ournal of the American Water Resources Association 42 (6):15971613. http:// dx.doi.org/ 10.1111/j.1752-1688.2006.tb06023.x

Noriega, G. R., J . R. Arrowsmith, L. B. Grant, and J . J . Young. 2006. Stream channel offset and Late Holocene slip rate of the San Andreas fault at the Van Matre Ranch site, Carrizo Plain, California. Bulletin of the Seismological Society of America 96 (1):33-47. http:// dx.doi.org/ 10.1785/ 0120050094

Opperman, J . J . 2005. Large woody debris and land management in California's hardwood-dominated watersheds. Environmental Management 35 (3):266-277. http:/ / dx.doi.org/ 10.1007/ s00267-004-0068-z

Oswalt, S. N., and S. L. King. 2005. Channelization and floodplain forests: Impacts of accelerated sedimentation and valley plug formation on floodplain forests of the Middle Fork Forked Deer River, Tennessee, USA. Forest Ecology and Management 215 (1-3):69-83. http:// dx.doi.org/ 10.1016/j.foreco.2005.05.004

Parker, G., and C. M. Toro-Escobar. 2002. Equal mobility of gravel in streams: The remains of the day. Water Resources Research 38 (11):461-468. http:/ / dx.doi.org/ 10.1029/ 2001WR000669

Pearce, S. A., and R. M. Grossinger. 2004. Relative effects of fluvial processes and historical land use on channel morphology in three sub-basins, Napa River basin, California, USA. IAHS-AISH Publication (288):170-178.

Pelletier, J . D., and S. DeLong. 2004. Oscillations in arid alluvial-channel geometry. Geology 32 (8): 713-716. http:/ / dx.doi.org/ 10.1130/ G20512.1

Pinter, N., K. Miller, J . H. Wlosinski, and R. R. Van Der Ploeg. 2004. Recurrent shoaling and channel dredging, Middle and Upper Mississippi River, USA. J ournal of Hydrology 290 (3-4):275-296. http:// dx.doi.org/ 10.1016/j.jhydrol.2003.12.021

Pitlick, J ., E. R. Mueller, C. Segura, R. Cress, and M. Torizzo. 2008. Relation between flow, surface-layer armoring and sediment transport in gravel-bed rivers. Earth Surface Processes and Landforms 33 (8):1192-1209. http:/ / dx.doi.org/ 10.1002/ esp.1607

Pizzuto, J ., and M. O'Neal. 2009. Increased mid-twentieth century riverbank erosion rates related to the demise of mill dams, South River, Virginia. Geology 37 (1):1922. http:/ / dx.doi.org/ 10.1130/G25207A.1

Poulton, B. C., M. L. Wildhaber, C. S. Charbonneau, J . F. Fairchild, B. G. Mueller, and C. J . Schmitt. 2003. A longitudinal assessment of the aquatic macroinvertebrate community in the channelized lower Missouri River. Environmental Monitoring and Assessment 85 (1):23-53. http:// dx.doi.org/ 10.1023/ A: 1023301016001

Rados, T., S. Sottung, D. Descaro, and D. Altland. 2002. Changing channels. Civil Engineering 72 (7):72-77. 
Rohasliney, H., and D. C. J ackson. 2008. Lignite mining and stream channelization influences on aquatic macroinvertebrate assemblages along the Natchez Trace Parkway, Mississippi, USA. Hydrobiologia 598 (1):149-162. http:// dx.doi.org/ 10.1007/ s10750-007-9147-5

Shields, F. D., Jr., R. R. Copeland, P. C. Klingeman, M. W. Doyle, and A. Simon. 2003. Design for stream restoration. J ournal of Hydraulic Engineering 129 (8):575584. http:/ / dx.doi.org/ 10.1061/(ASCE)0733-9429(2003)129: 8(575)

Shields, F. D., J r., S. S. Knight, and C. M. Cooper. 2007. Can warmwater streams be rehabilitated using watershed-scale standard erosion control measures alone? Environmental Management 40 (1):62-79. http:// dx.doi.org/ 10.1007/ s00267006-0191-0

Shields, F. D., J r., S. S. Knight, N. Morin, and J . Blank. 2003. Response of fishes and aquatic habitats to sand-bed stream restoration using large woody debris. Hydrobiologia 494:251-257. http:// dx.doi.org/ 10.1023/ A: 1025434920429

Shields, F. D., Jr., A. Simon, and S. M. Dabney. 2009. Streambank dewatering for increased stability. Hydrological Processes 23 (11):1537-1547. http:/ / dx.doi.org/ 10.1002/ hyp.7286

Shirinian-Orlando, A. A., and C. G. Uchrin. 2007. Modeling the hydrology and water quality using BASINS/ HSPF for the upper Maurice River watershed, NewJ ersey. J ournal of Environmental Science and Health - Part A Toxic/ Hazardous Substances and Environmental Engineering 42 (3):289-303. http:/ / dx.doi.org/ 10.1080/ 10934520601134254

Simon, A., and M. Rinaldi. 2000. Channel instability in the loess area of the midwestern United States. J ournal of the American Water Resources Association 36 (1):133150 .

Simon, A., M. Doyle, M. Kondolf, F. D. Shields J r, B. Rhoads, and M. McPhillips. 2007. Critical evaluation of how the Rosgen classification and associated "natural channel design" methods fail to integrate and quantify fluvial processes and channel response. J ournal of the American Water Resources Association 43 (5):1117-1131. http:/ / dx.doi.org/ 10.1111/j.1752-1688.2007.00091.x

Simon, A., N. Pollen-Bankhead, V. Mahacek, and E. Langendoen. 2009. Quantifying reductions of mass-failure frequency and sediment loadings from streambanks using toe protection and other means: Lake Tahoe, United States. J ournal of the American Water Resources Association 45 (1):170-186. http:// dx.doi.org/ 10.1111/j.1752-1688.2008.00268.x

Simon, A., R. E. Thomas, A. Curini, and F. D. Shields J r. 2002. Case study: Channel stability of the Missouri River, eastern Montana. J ournal of Hydraulic Engineering 128 (10):880-890.

Singer, M. B. 2008. Downstream patterns of bed material grain size in a large, lowland alluvial river subject to low sediment supply. Water Resources Research 44 (12). http:// dx.doi.org/ 10.1029/ 2008WR007183 
Sklar, L. S., and W. E. Dietrich. 2008. Implications of the saltation-abrasion bedrock incision model for steady-state river longitudinal profile relief and concavity. Earth Surface Processes and Landforms 33 (7):1129-1151. http:// dx.doi.org/ 10.1002/ esp.1689

Stark, C. P. 2006. A self-regulating model of bedrock river channel geometry. Geophysical Research Letters 33 (4). http:// dx.doi.org/ 10.1029/2005GL023193

Steinberger, N., and E. Wohl. 2003. Impacts to water quality and fish habitat associated with maintaining natural channels for flood control. Environmental Management 31(6):724-740. http:// dx.doi.org/ 10.1007/ s00267-003-2838-4

Stewart, T. L., and J . F. Martin. 2005. Energy model to predict suspended load deposition induced by woody debris: Case study. J ournal of Hydraulic Engineering 131 (11):1011-1016. http:// dx.doi.org/ 10.1061/ (ASCE)07339429(2005)131: 11(1011)

Sudduth, E. B., and J . L. Meyer. 2006. Effects of bioengineered streambank stabilization on bank habitat and macroinvertebrates in urban streams. Environmental Management 38 (2):218-226. http:// dx.doi.org/ 10.1007/ s00267-004-0381-6

Surbeck, C. Q., S. C. J iang, J . H. Ahn, and S. B. Grant. 2006. Flow fingerprinting fecal pollution and suspended solids in stormwater runoff from an urban coastal watershed. Environmental Science and Technology 40 (14):4435-4441. http:/ / dx.doi.org/ 10.1021/ es060701h

Svec, J . R., R. K. Kolka, and J . W. Stringer. 2005. Defining perennial, intermittent, and ephemeral channels in Eastern Kentucky: Application to forestry best management practices. Forest Ecology and Management 214 (1-3):170-182. http:// dx.doi.org/ 10.1016/j.foreco.2005.04.008

Thompson, D. M. 2002. Long-term effect of instream habitat-improvement structures on channel morphology along the Blackledge and Salmon rivers, Connecticut, USA. Environmental Management 29 (2):250-265. http:// dx.doi.org/ 10.1007/ s00267-001-0069-0

- 2003. A geomorphic explanation for a meander cutoff following channel relocation of a coarse-bedded river. Environmental Management 31 (3):385-400. http:// dx.doi.org/ 10.1007/ s00267-002-2842-0

Tucker, G. E., L. Arnold, R. L. Bras, H. Flores, E. Istanbulluoglu, and P. Solyom. 2006. Headwater channel dynamics in semiarid rangelands, Colorado high plains, USA. Bulletin of the Geological Society of America 118 (7-8):959-974. http:// dx.doi.org/ 10.1130/B25928.1

Vincent, K. R., J . M. Friedman, and E. R. Griffin. 2009. Erosional consequence of saltcedar control. Environmental Management 44 (2):218-227. http:// dx.doi.org/ 10.1007/ s00267-009-9314-8

Warren, D. R., and C. E. Kraft. 2006. Invertebrate community and stream substrate responses to woody debris removal from an ice storm-impacted stream system, NY USA. Hydrobiologia 568 (1):477-488. http:/ / dx.doi.org/ 10.1007/ s10750006-0218-9 
Wilcock, P. R., and B. T. DeTemple. 2005. Persistence of armor layers in gravel-bed streams. Geophysical Research Letters 32 (8):1-4. http:// dx.doi.org/ 10.1029/ 2004GL021772

Wilcock, P. R., S. T. Kenworthy, and J . C. Crowe. 2001. Experimental study of the transport of mixed sand and gravel. Water Resources Research 37 (12):33493358. http:// dx.doi.org/ 10.1029/2001WR000683

Wilson, G. V., R. K. Periketi, G. A. Fox, S. M. Dabney, F. D. Shields, and R. F. Cullum. 2007. Soil properties controlling seepage erosion contributions to streambank failure. Earth Surface Processes and Landforms 32 (3):447-459. http:/ / dx.doi.org/ 10.1002/ esp.1405

Wohl, E., J . N. Kuzma, and N. E. Brown. 2004. Reach-scale channel geometry of a mountain river. Earth Surface Processes and Landforms 29 (8):969-981. http:/ / dx.doi.org/ 10.1002/ esp.1078

Workman, R. D., D. B. Hayes, and T. G. Coon. 2004. Spawning habitat selection by rainbow trout in the Pere Marquette River, Michigan. J ournal of Great Lakes Research 30 (3):397-406.

Wynn, T., and S. Mostaghimi. 2006. The effects of vegetation and soil type on streambank erosion, Southwestern Virginia, USA. J ournal of the American Water Resources Association 42 (1):69-82.

Wynn, T. M., S. Mostaghimi, J . A. Burger, A. A. Harpold, M. B. Henderson, and L.-A. Henry. 2004. Variation in root density along stream banks. J ournal of Environmental Quality 33 (6):2030-2039.

Yang, C.-T. 2008. Applications of GSTARS computer models for solving river and reservoir sedimentation problems. Transactions of Tianjin University 14 (4):235-247. http:// dx.doi.org/ 10.1007/ s12209-008-0043-5 


\section{Appendix R: Water Quality}

Adams, R. M., M. R. Twiss, and C. T. Driscoll. 2009. Patterns of mercury accumulation among seston in lakes of the Adirondack Mountains, New York. Environmental Science and Technology 43 (13):4836-4842.

http:// dx.doi.org/ 10.1021/ es900409b

Anderson, B. S., B. M. Phillips, J . W. Hunt, K. Worcester, M. Adams, N. Kapellas, and R. S. Tjeerdema. 2006. Evidence of pesticide impacts in the Santa Maria River watershed, California, USA. Environmental Toxicology and Chemistry 25 (4):1160-1170. http:// dx.doi.org/ 10.1897/ 05-231R.1

Anisfeld, S. C., R. T. Barnes, M. A. Altabet, and T. Wu. 2007. Isotopic apportionment of atmospheric and sewage nitrogen sources in two Connecticut rivers.

Environmental Science and Technology 41(18):6363-6369.

http:// dx.doi.org/ 10.1021/ es070469v

Aparna, C., P. Saritha, V. Himabindu, and Y. Anjaneyulu. 2008. Techniques for the evaluation of maturity for composts of industrially contaminated lake sediments. Waste Management 28 (10):1773-1784. http:// dx.doi.org/ 10.1016/j.wasman.2007.07.008

Barber, L. B., S. H. Keefe, R. C. Antweiler, H. E. Taylor, and R. D. Wass. 2006. Accumulation of contaminants in fish from wastewater treatment wetlands. Environmental Science and Technology 40 (2):603-611. http:/ / dx.doi.org/ 10.1021/ es0514287

Behrends, L. L., E. Bailey, P.J ansen, L. Houke, and S. Smith. 2007. Integrated constructed wetland systems: Design, operation, and performance of low-cost decentralized wastewater treatment systems. Water Science and Technology 55 (7):155-161. http:// dx.doi.org/ 10.2166/ wst.2007.140

Bezbaruah, A. N., and T. C. Zhang. 2004. pH, redox, and oxygen microprofiles in rhizosphere of bulrush (Scirpus validus) in a constructed wetland treating municipal wastewater. Biotechnology and Bioengineering 88 (1):60-70. http:// dx.doi.org/ 10.1002/ bit.20208

—. 2005. Quantification of oxygen release by bulrush (Scirpus validus) roots in a constructed treatment wetland. Biotechnology and Bioengineering 89 (3):308318. http:// dx.doi.org/ 10.1002/ bit.20332

Blothe, M., D. M. Akob, J. E. Kostka, K. Goschel, H. L. Drake, and K. Kusel. 2008. pH gradient-induced heterogeneity of Fe(III)-reducing microorganisms in coal mining-associated lake sediments. Applied and Environmental Microbiology 74 (4):1019-1029. http:/ / dx.doi.org/ 10.1128/ AEM.01194-07

Brooks, M. L., J. S. Meyer, and D. M. McKnight. 2007. Photooxidation of wetland and riverine dissolved organic matter: Altered copper complexation and organic composition. Hydrobiologia 579 (1):95-113. http:// dx.doi.org/ 10.1007/ s10750006-0387-6 
Brooks, R., M. McKenney-Easterling, M. Brinson, R. Rheinhardt, K. Havens, D. O'Brien, J . Bishop, J . Rubbo, B. Armstrong, and J . Hite. 2009. A Stream-WetlandRiparian (SWR) index for assessing condition of aquatic ecosystems in small watersheds along the Atlantic slope of the eastern U.S. Environmental Monitoring and Assessment 150 (1-4):101-117. http:// dx.doi.org/ 10.1007/ s10661-008-0673-z

Chang, H., and T. N. Carlson. 2005. Water quality during winter storm events in Spring Creek, Pennsylvania USA. Hydrobiologia 544 (1):321-332. http:// dx.doi.org/ 10.1007/ s10750-005-1894-6

Chen, T. Y., C. M. Kao, T. Y. Yeh, H. Y. Chien, and A. C. Chao. 2006. Application of a constructed wetland for industrial wastewater treatment: A pilot-scale study. Chemosphere 64 (3):497-502. http:/ / dx.doi.org/ 10.1016/j.chemosphere.2005.11.069

Chilmakuri, C., J . A. McCorquodale, I. Georgiou, and J . Leal. 2005. The fate of stormwater runoff in an estuarine lake. Paper read at: 33rd CSCE Annual Conference 2005, June 2, 2005 - J une 4, 2005, at Toronto, ON, Canada.

Choi, J . H., S. S. Park, and P. R. J affe. 2006. The effect of emergent macrophytes on the dynamics of sulfur species and trace metals in wetland sediments.

Environmental Pollution 140 (2):286-293. http:// dx.doi.org/ 10.1016/j.envpol.2005.07.009

Cole, M. L., K. D. Kroeger, J . W. MoClelland, and I. Valiela. 2005. Macrophytes as indicators of land-derived wastewater: Application of a $15 \mathrm{~N}$ method in aquatic systems. Water Resources Research 41(1):1-9. http:/ / dx.doi.org/ 10.1029/ 2004WR003269

Conder, J . M., M. T. Sorensen, P. Leitman, L. B. Martello, and R. J . Wenning. 2009. Avian ecological risk potential in an urbanized estuary: Lower Hackensack River, NewJ ersey, U.S.A. Science of the Total Environment 407 (3): 1035-1047. http:/ / dx.doi.org/ 10.1016/j.scitotenv.2008.09.043

Conkle, J . L., J . R. White, and C. D. Metcalfe. 2008. Reduction of pharmaceutically active compounds by a lagoon wetland wastewater treatment system in Southeast Louisiana. Chemosphere 73 (11):1741-1748. http:// dx.doi.org/ 10.1016/j.chemosphere.2008.09.020

Connolly, J . P., H. A. Zahakos, J . Benaman, C. K. Ziegler, J . R. Rhea, and K. Russell. 2000. Model of PCB fate in the Upper Hudson River. Environmental Science and Technology 34 (19):4076-4087. http:// dx.doi.org/ 10.1021/ es001046v

Conroy, J . D., D. D. Kane, D. M. Dolan, W. J . Edwards, M. N. Charlton, and D. A. Culver. 2005. Temporal trends in Lake Erie plankton biomass: Roles of external phosphorus loading and Dreissenid mussels. J ournal of Great Lakes Research 31 (SUPPL. 2):89-110.

Crifasi, R. R. 2005. Reflections in a stock pond: Are anthropogenically derived freshwater ecosystems natural, artificial, or something else? Environmental Management 36 (5):625-639. http:/ / dx.doi.org/ 10.1007/ s00267-004-0147-1 
Crisman, T. L., C. Mitraki, and G. Zalidis. 2005. Integrating vertical and horizontal approaches for management of shallow lakes and wetlands. Ecological Engineering 24 (4 SPEC. ISS.):379-389. http://dx.doi.org/ 10.1016/j.ecoleng.2005.01.006

Darmody, R. G., J . C. Marlin, J. Talbott, R. A. Green, E. F. Brewer, and C. Stohr. 2004. Dredged Illinois River sediments: Plant growth and metal uptake. J ournal of Environmental Quality 33 (2):458-464.

Diaz, F. J ., A. T. Chow, A. T. O'Geen, R. A. Dahlgren, and P.-K. Wong. 2008. Restored wetlands as a source of disinfection byproduct precursors. Environmental Science and Technology 42 (16):5992-5997. http:// dx.doi.org/ 10.1021/ es800781n

Dierberg, F. E., J . J J uston, T. A. DeBusk, K. Pietro, and B. Gu. 2005. Relationship between hydraulic efficiency and phosphorus removal in a submerged aquatic vegetation-dominated treatment wetland. Ecological Engineering 25 (1):9-23. http:// dx.doi.org/ 10.1016/j.ecoleng.2004.12.018

Dodds, W. K., and M. R. Whiles. 2004. Quality and quantity of suspended particles in rivers: Continent-scale patterns in the United States. Environmental Management 33 (3):355-367. http: / / dx.doi.org/ 10.1007/ s00267-003-0089-z

Durant, J . L., T. Ivushkina, K. MacLaughlin, H. Lukacs, J . Gawel, D. Senn, and H. F. Hemond. 2004. Elevated levels of arsenic in the sediments of an urban pond: Sources, distribution and water quality impacts. Water Research 38 (13):29893000. http:// dx.doi.org/ 10.1016/j.watres.2004.04.010

Eleria, A., and R. M. Vogel. 2005. Predicting fecal coliform bacteria levels in the Charles River, Massachusetts, USA. J ournal of the American Water Resources Association 41(5):1195-1209.

Elliott, E. M., and G. S. Brush. 2006. Sedimented organic nitrogen isotopes in freshwater wetlands record long-term changes in watershed nitrogen source and land use. Environmental Science and Technology 40 (9):2910-2916. http:// dx.doi.org/ 10.1021/ es051587q

Fisher, T. R., J . A. Benitez, K.-Y. Lee, and A. J . Sutton. 2006. History of land cover change and biogeochemical impacts in the Choptank River basin in the mid-Atlantic region of the US. International J ournal of Remote Sensing 27 (17):3683-3703. http:// dx.doi.org/ 10.1080/ 01431160500500383

Flemer, D. A., and M. A. Champ. 2006. What is the future fate of estuaries given nutrient over-enrichment, freshwater diversion and low flows? Marine Pollution Bulletin 52 (3):247-258. http:// dx.doi.org/ 10.1016/j.marpolbul.2005.11.027

Foltz, S. J ., and S. I. Dodson. 2009. Aquatic Hemiptera community structure in stormwater retention ponds: A watershed land cover approach. Hydrobiologia 621 (1):49-62. http:// dx.doi.org/ 10.1007/s10750-008-9631-6 
Gao, N., N. G. Armatas, J . B. Shanley, N. C. Kamman, E. K. Miller, G. J . Keeler, T. Scherbatskoy, T. M. Holsen, T. Young, L. Mcllroy, S. Drake, B. Olsen, and C. Cady. 2006. Mass balance assessment for mercury in Lake Champlain. Environmental Science and Technology 40 (1):82-89. http:// dx.doi.org/ 10.1021/ es050513b

Gathumbi, S. M., P. J . Bohlen, and D. A. Graetz. 2005. Nutrient enrichment of wetland vegetation and sediments in subtropical pastures. Soil Science Society of America J ournal 69 (2):539-548.

Gessner, T. P., R. H. Kadlec, and R. P. Reaves. 2005. Wetland remediation of cyanide and hydrocarbons. Ecological Engineering 25 (4):457-469.

http:// dx.doi.org/ 10.1016/j.ecoleng.2005.07.015

Gilchrist, S., A. Gates, Z. Szabo, and P. J . Lamothe. 2009. Impact of AMD on water quality in critical watershed in the Hudson River drainage basin: Phillips Mine, Hudson Highlands, New York. Environmental Geology 57 (2):397-409. http:/ / dx.doi.org/ 10.1007/ s00254-008-1310-4

Godfrey, E., W. W. Woessner, and M. J. Benotti. 2007. Pharmaceuticals in on-site sewage effluent and ground water, Western Montana. Ground Water 45 (3):263-271. http:/ / dx.doi.org/ 10.1111/j.1745-6584.2006.00288.x

Gomez-Hermosillo, C., J . H. Pardue, and D. D. Reible. 2006. Wetland plant uptake of desorption-resistant organic compounds from sediments. Environmental Science and Technology 40 (10):3229-3236. http:/ / dx.doi.org/ 10.1021/ es051341l

Grove, J . K., and O. R. Stein. 2005. Polar organic solvent removal in microcosm constructed wetlands. Water Research 39 (16):4040-4050. http:// dx.doi.org/ 10.1016/j.watres.2005.07.023

Hafner, S. D., and W. J . J ewell. 2006. Predicting nitrogen and phosphorus removal in wetlands due to detritus accumulation: A simple mechanistic model. Ecological Engineering 27 (1):13-21. http:// dx.doi.org/ 10.1016/j.ecoleng.2005.09.014

Hargreaves, J . A., C. S. Tucker, E. R. Thornton, and S. K. Kingsbury. 2005. Characteristics and sedimentation of initial effluent discharged from excavated levee ponds for channel catfish. Aquacultural Engineering 33 (2):96-109. http:// dx.doi.org/ 10.1016/j.aquaeng.2004.10.002

Harmon, S. M., J. K. King, J . B. Gladden, G. T. Chandler, and L. A. Newman. 2004. Methylmercury formation in a wetland mesocosm amended with sulfate. Environmental Science and Technology 38 (2):650-656. http:// dx.doi.org/ 10.1021/ es030513g

Hellweger, F. L., and P. Masopust. 2008. Investigating the fate and transport of Escherichia coli in the Charles River, Boston, using high-resolution observation and modeling. J ournal of the American Water Resources Association 44 (2):509-522. http:// dx.doi.org/ 10.1111/j.1752-1688.2008.00179.x

Hench, K. R., A. J . Sexstone, and G. K. Bissonnette. 2004. Heterotrophic communitylevel physiological profiles of domestic wastewater following treatment by small constructed subsurface flow wetlands. Water Environment Research 76 (5):468473. http:// dx.doi.org/ 10.2175/ 106143004X151554 
Hernandez, M. E., and W. J . Mitsch. 2007. Denitrification in created riverine wetlands: Influence of hydrology and season. Ecological Engineering 30 (1):78-88. http:// dx.doi.org/ 10.1016/j.ecoleng.2007.01.015

Horowitz, A. J . 2004. Monitoring suspended sediment and associated trace element and nutrient fluxes in large river basins in the USA. IAHS-AISH Publication (288):419-428.

Howell, C. J., D. M. Crohn, and M. Omary. 2005. Simulating nutrient cycling and removal through treatment wetlands in arid/ semiarid environments. Ecological Engineering 25 (1):25-39. http:// dx.doi.org/ 10.1016/j.ecoleng.2005.02.007

Hu, H., S. E. Mylon, and G. Benoit. 2007. Volatile organic sulfur compounds in a stratified lake. Chemosphere 67 (5):911-919. http:// dx.doi.org/ 10.1016/j.chemosphere.2006.11.012

Hwang, H.-M., P. G. Green, and R. W. Holmes. 2009. Anthropogenic impacts on the quality of streambed sediments in the lower Sacramento River watershed, California. J ournal of Environmental Science and Health - Part A Toxic/ Hazardous Substances and Environmental Engineering 44 (1):1-11. http:/ / dx.doi.org/ 10.1080/ 10934520802515137

Ishida, C. K., J . J . Kelly, and K. A. Gray. 2006. Effects of variable hydroperiods and water level fluctuations on denitrification capacity, nitrate removal, and benthicmicrobial community structure in constructed wetlands. Ecological Engineering 28 (4):363-373. http:// dx.doi.org/ 10.1016/j.ecoleng.2006.06.010

J aisi, D. P., S. Ji, H. Dong, R. E. Blake, D. D. Eberl, and J . Kim. 2008. Role of microbial $\mathrm{Fe}$ (III) reduction and solution chemistry in aggregation and settling of suspended particles in the Mississippi River Delta plain, Louisiana, USA. Clays and Clay Minerals 56 (4):416-428. http:// dx.doi.org/ 10.1346/ CCMN.2008.0560403

J eng, H., and Y.-J . Hong. 2005. Assessment of a natural wetland for use in wastewater remediation. Environmental Monitoring and Assessment 111 (1-3):113-131. http:// dx.doi.org/ 10.1007/ s10661-005-8217-2

J eremiason, J . D., D. R. Engstrom, E. B. Swain, E. A. Nater, B. M. J ohnson, J . E. Almendinger, B. A. Monson, and R. K. Kolka. 2006. Sulfate addition increases methylmercury production in an experimental wetland. Environmental Science and Technology 40 (12):3800-3806. http:// dx.doi.org/ 10.1021/ es0524144

J in, G., and T. R. Kelley. 2007. Characterization of microbial communities in a pilot-scale constructed wetland using PLFA and PCR-DGGE analyses. J ournal of Environmental Science and Health - Part A Toxic/ Hazardous Substances and Environmental Engineering 42 (11):1639-1647. http:// dx.doi.org/ 10.1080/ 10934520701518125

J ones, R. C., D. P. Kelso, and E. Schaeffer. 2008. Spatial and seasonal patterns in water quality in an embayment-mainstem reach of the tidal freshwater Potomac River, USA: A multiyear study. Environmental Monitoring and Assessment 147 (1-3):351-375. http:// dx.doi.org/ 10.1007/ s10661-007-0126-0 
Kadlec, R. H. 2005. Phosphorus removal in emergent free surface wetlands. J ournal of Environmental Science and Health - Part A Toxic/ Hazardous Substances and Environmental Engineering 40 (6-7):1293-1306. http:// dx.doi.org/ 10.1081/ ESE-200055832

— 2005. Wetland to pond treatment gradients. Water Science and Technology 51(9):291-298.

- 2008. The effects of wetland vegetation and morphology on nitrogen processing. Ecological Engineering 33 (2):126-141.

http://dx.doi.org/ 10.1016/j.ecoleng.2008.02.012

_. 2009. Comparison of free water and horizontal subsurface treatment wetlands. Ecological Engineering 35 (2):159-174.

http:// dx.doi.org/ 10.1016/j.ecoleng.2008.04.008

- 2009. Wastewater treatment at the Houghton Lake wetland: Hydrology and water quality. Ecological Engineering 35 (9):1287-1311. http:// dx.doi.org/ 10.1016/j.ecoleng.2008.10.001

Kadlec, R. H., and F. B. Bevis. 2009. Wastewater treatment at the Houghton Lake wetland: Vegetation response. Ecological Engineering 35 (9):1312-1332. http:// dx.doi.org/ 10.1016/j.ecoleng.2008.11.001

Karim, M. R., F. D. Manshadi, M. M. Karpiscak, and C. P. Gerba. 2004. The persistence and removal of enteric pathogens in constructed wetlands. Water Research 38 (7):1831-1837. http:// dx.doi.org/ 10.1016/j.watres.2003.12.029

Kelly, W. R., H. A. Wehrmann, T. R. Holm, J . L. Talbott, and L. M. Skowron. 2003. Subsurface movement of zinc from contaminated dredge spoils at a periodically flooded site. Environmental Geology 45 (1):23-34. http:// dx.doi.org/ 10.1007/ s00254-003-0855-5

Kincaid, T. M., D. P. Larsen, and N. S. Urquhart. 2004. The structure of variation and its influence on the estimation of status: Indicators of condition of lakes in the Northeast, U.S.A. Environmental Monitoring and Assessment 98 (1-3):1-21. http:/ / dx.doi.org/ 10.1023/ B:EMAS.0000038176.68766.71

Knox, A. S., D. L. Dunn, M. H. Paller, E. A. Nelson, W. L. Specht, and J . C. Seaman. 2006. Assessment of contaminant retention in constructed wetland sediments. Engineering in Life Sciences 6 (1):31-36. http:// dx.doi.org/ 10.1002/ elsc.200620116

Kohler, E. A., V. L. Poole, Z. J . Reicher, and R. F. Turco. 2004. Nutrient, metal, and pesticide removal during storm and nonstorm events by a constructed wetland on an urban golf course. Ecological Engineering 23 (4-5):285-298. http:// dx.doi.org/ 10.1016/j.ecoleng.2004.11.002

Kroger, R., M. T. Moore, M. A. Locke, R. F. Cullum, R. W. Steinriede, Jr., S. Testa, III, C. T. Bryant, and C. M. Cooper. 2009. Evaluating the influence of wetland vegetation on chemical residence time in Mississippi Delta drainage ditches. Agricultural Water Management 96 (7):1175-1179. http:// dx.doi.org/ 10.1016/j.agwat.2009.03.002 
Lansing, S. L., and J . F. Martin. 2006. Use of an ecological treatment system (ETS) for removal of nutrients from dairy wastewater. Ecological Engineering 28 (3 SPEC. ISS.):235-245. http:// dx.doi.org/ 10.1016/j.ecoleng.2006.04.006

LaSage, D. M., A. E. Fryar, A. Mukherjee, N. C. Sturchio, and L. J . Heraty. 2008. Groundwater-derived contaminant fluxes along a channelized Coastal Plain stream. J ournal of Hydrology 360 (1-4):265-280. http:// dx.doi.org/ 10.1016/j.jhydrol.2008.07.026

Leader, J. W., K. R. Reddy, and A. C. Wilkie. 2005. Optimization of low-cost phosphorus removal from wastewater using co-treatments with constructed wetlands. Water Science and Technology 51 (9):283-290.

Lee, S., J . H. Pardue, W. M. Moe, and D. J . Kim. 2009. Effect of sorption and desorptionresistance on biodegradation of chlorobenzene in two wetland soils. J ournal of Hazardous Materials 161(1):492-498. http:// dx.doi.org/ 10.1016/j.jhazmat.2008.03.129

Li, C., J . Cui, G. Sun, and C. Trettin. 2004. Modeling impacts of management on carbon sequestration and trace gas emissions in forested wetland ecosystems. Environmental Management 33 (SUPPL. 1):S176-S186. http://dx.doi.org/ 10.1007/ s00267-003-9128-z

Lorah, M. M., and M. A. Voytek. 2004. Degradation of 1,1,2,2-tetrachloroethane and accumulation of vinyl chloride in wetland sediment microcosms and in situ porewater: Biogeochemical controls and associations with microbial communities. J ournal of Contaminant Hydrology 70 (1-2):117-145. http:// dx.doi.org/ 10.1016/j.jconhyd.2003.08.010

Manios, T., M. S. Fountoulakis, and A. D. Karathanasis. 2009. Construction simplicity and cost as selection criteria between two types of constructed wetlands treating highway runoff. Environmental Management 43 (5):908-920. http:// dx.doi.org/ 10.1007/s00267-008-9250-z

Mankin, K. R., and C. D. Ikenberry. 2004. Batch reactor unvegetated wetland performance in treating dairy wastewater. J ournal of the American Water Resources Association 40 (6):1527-1535.

Mayhew, C. R., D. R. Raman, R. R. Gerhardt, R. T. Burns, and M. S. Younger. 2004. Periodic draining reduces mosquito emergence from free-water surface constructed wetlands. Transactions of the American Society of Agricultural Engineers 47 (2):567-573.

McLain, J. E. T., and C. F. Williams. 2008. Seasonal variation in accurate identification of Escherichia coli within a constructed wetland receiving tertiary-treated municipal effluent. Water Research 42 (15):4041-4048. http://dx.doi.org/ 10.1016/j.watres.2008.06.003

Meyer, J. L., D. L. Strayer, J . B. Wallace, S. L. Eggert, G. S. Helfman, and N. E. Leonard. 2007. The contribution of headwater streams to biodiversity in river networks. J ournal of the American Water Resources Association 43 (1):86-103. http:// dx.doi.org/ 10.1111/j.1752-1688.2007.00008.x 
Money, E. S., G. P. Carter, and M. L. Serre. 2009. Modern space/ time geostatistics using river distances: Data integration of turbidity and E. coli measurements to assess fecal contamination along the Raritan River in NewJ ersey. Environmental Science and Technology 43 (10):3736-3742. http:// dx.doi.org/ 10.1021/ es803236j

Moore, M. T., C. M. Cooper, S. Smith Jr, R. F. Cullum, S. S. Knight, M. A. Locke, and E. R. Bennett. 2007. Diazinon mitigation in constructed wetlands: Influence of vegetation. Water, Air, and Soil Pollution 184 (1-4):313-321. http:// dx.doi.org/ 10.1007/ s11270-007-9418-9

Morrice, J . A., N. P. Danz, R. R. Regal, J . R. Kelly, G. J . Niemi, E. D. Reavie, T. Hollenhorst, R. P. Axler, A. S. Trebitz, A. M. Cotter, and G. S. Peterson. 2008. Human influences on water quality in Great Lakes coastal wetlands. Environmental Management 41 (3):347-357. http:// dx.doi.org/ 10.1007/ s00267-007-9055-5

Murtaugh, P. A., and P. S. Pooler. 2006. Evaluating ecological indicators: Lakes in the Northeastern United States. Environmental Monitoring and Assessment 119 (1-3):83-96. http:// dx.doi.org/ 10.1007/s10661-005-9011-x

Neatrour, M. A., R. H. J ones, and S. W. Golladay. 2005. Correlations between soil nutrient availability and fine-root biomass at two spatial scales in forested wetlands with contrasting hydrological regimes. Canadian J ournal of Forest Research 35 (12):2934-2941. http:// dx.doi.org/ 10.1139/x05-217

Nelson, E. A., W. L. Specht, and A. S. Knox. 2006. Metal removal from water discharges by a constructed treatment wetland. Engineering in Life Sciences 6 (1):26-30. http:/ / dx.doi.org/ 10.1002/ elsc.200620112

Nicomrat, D., W. A. Dick, and O. H. Tuovinen. 2006. Microbial populations identified by fluorescence in situ hybridization in a constructed wetland treating acid coal mine drainage. J ournal of Environmental Quality 35 (4):1329-1337. http:// dx.doi.org/ 10.2134/ jeq2005.0325

Nicomrat, D., W. A. Dick, M. Dopson, and O. H. Tuovinen. 2008. Bacterial phylogenetic diversity in a constructed wetland system treating acid coal mine drainage. Soil Biology and Biochemistry 40 (2):312-321. http:// dx.doi.org/ 10.1016/j.soilbio.2007.08.009

Nivala, J ., M. B. Hoos, C. Cross, S. Wallace, and G. Parkin. 2007. Treatment of landfill leachate using an aerated, horizontal subsurface-flow constructed wetland. Science of the Total Environment 380 (1-3):19-27. http:// dx.doi.org/ 10.1016/j.scitotenv.2006.12.030

Park, N., B. J . Vanderford, S. A. Snyder, S. Sarp, S. D. Kim, and J . Cho. 2009. Effective controls of micropollutants included in wastewater effluent using constructed wetlands under anoxic condition. Ecological Engineering 35 (3):418-423. http:// dx.doi.org/ 10.1016/j.ecoleng.2008.10.004

Parsons, M. J., D. T. Long, S. S. Yohn, and J. P. Giesy. 2007. Spatial and temporal trends of mercury loadings to Michigan inland lakes. Environmental Science and Technology 41 (16):5634-5640. http:// dx.doi.org/ 10.1021/ es0701356 
Peeler, K. A., S. P. Opsahl, and J . P. Chanton. 2006. Tracking anthropogenic inputs using caffeine, indicator bacteria, and nutrients in rural freshwater and urban marine systems. Environmental Science and Technology 40 (24):7616-7622. http:/ / dx.doi.org/ 10.1021/ es061213c

Peterson, S. A., J . Van Sickle, A. T. Herlihy, and R. M. Hughes. 2007. Mercury concentration in fish from streams and rivers throughout the western United States. Environmental Science and Technology 41 (1):58-65. http:/ / dx.doi.org/ 10.1021/ es061070u

Poach, M. E., P. G. Hunt, G. B. Reddy, K. C. Stone, M. H. J ohnson, and A. Grubbs. 2004. Swine wastewater treatment by marsh-pond-marsh constructed wetlands under varying nitrogen loads. Ecological Engineering 23 (3):165-175. http:/ / dx.doi.org/ 10.1016/j.ecoleng.2004.09.001

- 2007. Effect of intermittent drainage on swine wastewater treatment by marshpond-marsh constructed wetlands. Ecological Engineering 30 (1):43-50. http:// dx.doi.org/ 10.1016/j.ecoleng.2007.01.003

Prochaska, C. A., A. I. Zouboulis, and K. M. Eskridge. 2007. Performance of pilot-scale vertical-flow constructed wetlands, as affected by season, substrate, hydraulic load and frequency of application of simulated urban sewage. Ecological Engineering 31 (1):57-66. http:// dx.doi.org/ 10.1016/j.ecoleng.2007.05.007

Riley, K. A., O. R. Stein, and P. B. Hook. 2005. Ammonium removal in constructed wetland microcosms as influenced by season and organic carbon load. J ournal of Environmental Science and Health - Part A Toxic/ Hazardous Substances and Environmental Engineering 40 (6-7):1109-1121. http: / / dx.doi.org/ 10.1081/ ESE200055594

Robinson, G. R., J r., and R. A. Ayuso. 2004. Use of spatial statistics and isotopic tracers to measure the influence of arsenical pesticide use on stream sediment chemistry in New England, USA. Applied Geochemistry 19 (7):1097-1110.

Sahoo, G. B., C. Ray, J . Z. Wang, S. A. Hubbs, R. Song, J . J asperse, and D. Seymour. 2005. Use of artificial neural networks to evaluate the effectiveness of riverbank filtration. Water Research 39 (12):2505-2516. http:// dx.doi.org/ 10.1016/j.watres.2005.04.020

Seo, D. C., S. H. Hwang, H. J . Kim, J . S. Cho, H. J . Lee, R. D. DeLaune, A. J ugsujinda, S. T. Lee, J. Y. Seo, and J. S. Heo. 2008. Evaluation of 2- and 3-stage combinations of vertical and horizontal flow constructed wetlands for treating greenhouse wastewater. Ecological Engineering 32 (2):121-132. http:// dx.doi.org/ 10.1016/j.ecoleng.2007.10.007

Shellenbarger, G. G., N. D. Athearn, J . Y. Takekawa, and A. B. Boehm. 2008. Fecal indicator bacteria and Salmonella in ponds managed as bird habitat, San Francisco Bay, California, USA. Water Research 42 (12):2921-2930. http:// dx.doi.org/ 10.1016/j.watres.2008.03.006

Shen, J ., J .-J . J ia, and G. M. Sisson. 2006. Inverse estimation of nonpoint sources of fecal coliform for establishing allowable load for Wye River, Maryland. Water Research 40 (18):3333-3342. http:// dx.doi.org/ 10.1016/j.watres.2006.07.035 
Simon, N. S., O. P. Bricker, W. Newell, J . McCoy, and R. Morawe. 2005. The distribution of phosphorus in Popes Creek, VA, and in the Pocomoke River, MD: Two watersheds with different land management practices in the Chesapeake Bay Basin. Water, Air, and Soil Pollution 164 (1-4):189-204. http://dx.doi.org/ 10.1007/ s11270-005-3024-5

Sirivedhin, T., and K. A. Gray. 2006. Factors affecting denitrification rates in experimental wetlands: Field and laboratory studies. Ecological Engineering 26 (2):167-181. http:// dx.doi.org/ 10.1016/j.ecoleng.2005.09.001

Sprague, L. A., and D. L. Lorenz. 2009. Regional nutrient trends in streams and rivers of the United States, 1993-2003. Environmental Science and Technology 43 (10):3430-3435. http:// dx.doi.org/ 10.1021/ es803664x

Steer, D. N., L. H. Fraser, and B. A. Seibert. 2005. Cell-to-cell pollution reduction effectiveness of subsurface domestic treatment wetlands. Bioresource Technology 96 (8):969-976. http:// dx.doi.org/ 10.1016/j.biortech.2004.08.006

Stein, O. R., B. W. Towler, P. B. Hook, and J . A. Biederman. 2007. On fitting the k-C* first order model to batch loaded sub-surface treatment wetlands. Water Science and Technology 56 (3):93-99. http:// dx.doi.org/ 10.2166/ wst.2007.515

Stein, O. R., D. J . Borden-Stewart, P. B. Hook, and W. L. J ones. 2007. Seasonal influence on sulfate reduction and zinc sequestration in subsurface treatment wetlands. Water Research 41(15):3440-3448. http:// dx.doi.org/ 10.1016/j.watres.2007.04.023

Stein, O. R., J . A. Biederman, P. B. Hook, and W. C. Allen. 2006. Plant species and temperature effects on the k-C* first-order model for COD removal in batchloaded SSF wetlands. Ecological Engineering 26 (2):100-112. http:// dx.doi.org/ 10.1016/j.ecoleng.2005.07.001

Steinberg, L. M., and J . M. Regan. 2008. Phylogenetic comparison of the methanogenic communities from an acidic, oligotrophic fen and an anaerobic digester treating municipal wastewater sludge. Applied and Environmental Microbiology 74 (21):6663-6671. http:// dx.doi.org/ 10.1128/ AEM.00553-08

Stringfellow, W. T., J. S. Hanlon, S. E. Borglin, and N. W. T. Quinn. 2008. Comparison of wetland and agriculture drainage as sources of biochemical oxygen demand to the San J oaquin River, California. Agricultural Water Management 95 (5):527538. http:/ / dx.doi.org/ 10.1016/j.agwat.2007.12.007

Struck, S. D., A. Selvakumar, and M. Borst. 2008. Prediction of effluent quality from retention ponds and constructed wetlands for managing bacterial stressors in storm-water runoff. J ournal of Irrigation and Drainage Engineering 134 (5):567-578. http:// dx.doi.org/ 10.1061/ (ASCE)0733-9437(2008)134:5(567)

Sullivan, T. J ., B. J . Cosby, A. T. Herlihy, C. T. Driscoll, I. J . Fernandez, T. C. McDonnell, C. W. Boylen, S. A. Nierzwicki-Bauer, and K. U. Snyder. 2007. Assessment of the extent to which intensively-studied lakes are representative of the Adirondack region and response to future changes in acidic deposition. Water, Air, and Soil Pollution 185 (1-4):279-291. http:// dx.doi.org/10.1007/ s11270-007-9449-2 
Sun, G., and D. Austin. 2007. A mass balance study on nitrification and deammonification in vertical flow constructed wetlands treating landfill leachate. Water Science and Technology 56 (3):117-123. http:/ / dx.doi.org/ 10.2166/ wst.2007.503

Surampalli, R. Y., S. K. Banerji, R. D. Tyagi, and P. Y. Yang. 2007. Integrated advanced natural wastewater treatment system for small communities. Water Science and Technology 55 (11):239-243. http:/ / dx.doi.org/ 10.2166/ wst.2007.371

Tao, W., and J. Wang. 2009. Effects of vegetation, limestone and aeration on nitritation, anammox and denitrification in wetland treatment systems. Ecological Engineering 35 (5):836-842. http:// dx.doi.org/ 10.1016/j.ecoleng.2008.12.003

Totten, L. A., M. Panangadan, S. J . Eisenreich, G. J . Cavallo, and T. J . Fikslin. 2006. Direct and indirect atmospheric deposition of PCBs to the Delaware River watershed. Environmental Science and Technology 40 (7):2171-2176. http:// dx.doi.org/ 10.1021/ es052149m

Turner, B. L., and S. Newman. 2005. Phosphorus cycling in wetland soils: The importance of phosphate diesters. J ournal of Environmental Quality 34 (5):1921-1929. http: / / dx.doi.org/ 10.2134/ jeq2005.0060

Tweel, A. W., and P. J . Bohlen. 2008. Influence of soft rush (J uncus effusus) on phosphorus flux in grazed seasonal wetlands. Ecological Engineering 33 (3-4):242-251. http:// dx.doi.org/ 10.1016/j.ecoleng.2008.05.003

Warren, W. J ., R. M. J eter, R. C. Kimbrough, and J . C. Zak. 2004. Population patterns and antimicrobial resistance of Aeromonas in urban playa lakes. Canadian J ournal of Microbiology 50 (6):397-404. http:// dx.doi.org/ 10.1139/ w04-029

Watras, C. J ., K. A. Morrison, A. Kent, N. Price, O. Regnell, C. Eckley, H. Hintelmann, and T. Hubacher. 2005. Sources of methylmercury to a wetland-dominated lake in northern Wisconsin. Environmental Science and Technology 39 (13):4747-4758. http:/ / dx.doi.org/ 10.1021/ es040561g

Whitman, R. L., K. Przybyla-Kelly, D. A. Shively, M. B. Nevers, and M. N. Byappanahalli. 2008. Sunlight, season, snowmelt, storm, and source affect E. coli populations in an artificially ponded stream. Science of the Total Environment 390 (2-3):448455. http:// dx.doi.org/ 10.1016/j.scitotenv.2007.10.014

Whitmire, S. L., and S. K. Hamilton. 2005. Rapid removal of nitrate and sulfate in freshwater wetland sediments. J ournal of Environmental Quality 34 (6):20622071. http:// dx.doi.org/ 10.2134/jeq2004.0483

Williams, M., C. Hopkinson, E. Rastetter, J . Vallino, and L. Claessens. 2005. Relationships of land use and stream solute concentrations in the Ipswich River basin, northeastern Massachusetts. Water, Air, and Soil Pollution 161(1-4):5574. http:// dx.doi.org/ 10.1007/ s11270-005-2830-0

Wu, J ., J . Zhang, W. Jia, H. Xie, R. R. Gu, C. Li, and B. Gao. 2009. Impact of COD/ N ratio on nitrous oxide emission from microcosm wetlands and their performance in removing nitrogen from wastewater. Bioresource Technology 100 (12):29102917. http:// dx.doi.org/ 10.1016/j.biortech.2009.01.056 
Zazo, J . A., J . S. Paull, and P. R. J affe. 2008. Influence of plants on the reduction of hexavalent chromium in wetland sediments. Environmental Pollution 156 (1):2935. http:// dx.doi.org/ 10.1016/j.envpol.2008.01.006

Zeng, X., and T. C. Rasmussen. 2005. Multivariate statistical characterization of water quality in Lake Lanier, Georgia, USA. J ournal of Environmental Quality 34 (6):1980-1991. http:// dx.doi.org/ 10.2134/jeq2004.0337

Zhang, Y., and W. T. Frankenberger Jr. 2005. Removal of selenium from river water by a microbial community enhanced with Enterobacter taylorae in organic carbon coated sand columns. Science of the Total Environment 346 (1-3):280-285. http:// dx.doi.org/ 10.1016/j.scitotenv.2005.02.019

Zhu, J ., and C. R. Olsen. 2009. Beryllium-7 atmospheric deposition and sediment inventories in the Neponset River estuary, Massachusetts, USA. J ournal of Environmental Radioactivity 100 (2):192-197. http:/ / dx.doi.org/ 10.1016/j.jenvrad.2008.11.013 


\section{Appendix S: Wetlands and Wildlife}

Argent, D. G., and R. J . Zwier. 2007. Seasonal use of recently fenced agricultural riparian habitat by avifauna in Pennsylvania. Northeastern Naturalist 14 (3):361-374.

Ashley, M. C., J . A. Robinson, L. W. Oring, and G. A. Vinyard. 2000. Dipteran standing stock biomass and effects of aquatic bird predation at a constructed wetland. Wetlands 20 (1):84-90.

Aznar, J . C., and A. Desrochers. 2008. Building for the future: Abandoned beaver ponds promote bird diversity. Ecoscience 15 (2):250-257.

Balcombe, C. K., J . T. Anderson, R. H. Fortney, and W. S. Kordek. 2005. Wildlife use of mitigation and reference wetlands in West Virginia. Ecological Engineering 25 (1):85-99.

http:// www.sciencedirect.com/science?_ob=MImg\&_imagekey=B6VFB4G94HHW-1-

$3 \&$ _cdi $=6006 \&$ _ user $=930810 \&$ \& orig $=$ search\&_coverDate $=07 \% 2 \mathrm{~F} 20 \% 2 \mathrm{~F} 2005$ \& sk=999749998\&view $=$ c\&wchp $=$ dGLbVtz-

zSאkzS\&md5=8f414c321ff131d443f9475c853fele3\&ie=/ sdarticle.pdf

Barrett, K., and C. Guyer. 2008. Differential responses of amphibians and reptiles in riparian and stream habitats to land use disturbances in western Georgia, USA. Biological Conservation 141(9):2290-2300.

http:// www.sciencedirect.com/science?_ob=MImg\&_imagekey=B6V5X4T4HJJ 5-1-

$7 \& \_$cdi $=5798 \& \_$user $=930810 \&$ \& orig $=$ search\&_coverDate $=09 \% 2 \mathrm{~F} 30 \% 2 \mathrm{~F} 2008$

\& sk=998589990\&view=c\&wchp=dGLbVlz-

zŜKWb\&md5=1c10ea16bf3a2323f5f3d655762f4b24\&ie=/ sdarticle.pdf

Beachy, B. L., and G. R. Robinson. 2008. Divergence in avian communities following woody plant invasions in a pine barrens ecosystem. Natural Areas J ournal 28 (4):395-403.

Bogner, H. E., and G. A. Baldassarre. 2002. Home range, movement, and nesting of Least Bitterns in western New York. Wilson Bulletin 114 (3):297-308.

Brasher, M. G., J . D. Steckel, and R. J . Gates. 2007. Energetic carrying capacity of actively and passively managed wetlands for migrating ducks in Ohio. J ournal of Wildlife Management 71 (8):2532-2541. http:/ / dx.doi.org/ 10.2193/ 2006-401

Bub, B. R., D. J . Flaspohler, and C. J . F. Huckins. 2004. Riparian and upland breedingbird assemblages along headwater streams in Michigan's Upper Peninsula. J ournal of Wildlife Management 68 (2):383-392.

Bulluck, J . F., and M. P. Rowe. 2006. The use of southern Appalachian wetlands by breeding birds, with a focus on Neotropical migratory species. Wilson J ournal of Ornithology 118 (3):399-410. 
Calhoun, A. J . K., and P. deMaynadier. 2004. Forestry habitat management guidelines for vernal pool wildlife. Bronx, NY.

Carter, T. C. 2006. Indiana bats in the Midwest: The importance of hydric habitats. J ournal of Wildlife Management 70 (5):1185-1190.

Chalmers, R. J ., and C. S. Loftin. 2006. Wetland and microhabitat use by nesting FourToed Salamanders in Maine. J ournal of Herpetology 40 (4):478-485.

Champlin, T. B., J . C. Kilgo, and C. E. Moorman. 2009. Food abundance does not determine bird use of early-successional habitat. Ecology 90 (6):1586-1594.

Champlin, T. B., J . C. Kilgo, M. L. Gumpertz, and C. E. Moorman. 2009. Avian response to microclimate in canopy gaps in a bottomland hardwood forest. Southeastern Naturalist 8 (1):107-120.

Chandler, R. B., D. I. King, and S. DeStefano. 2009. Scrub-shrub bird habitat associations at multiple spatial scales in beaver meadows in Massachusetts. Auk 126 (1):186197.

Coleman, J. L., N. B. Ford, and K. Herriman. 2008. A road survey of amphibians and reptiles in a bottomland hardwood forest. Southeastern Naturalist 7 (2):339348.

Conner, R. N., J . G. Dickson, J . H. Williamson, and B. N. Ortego. 2004. Width of forest streamside zones and breeding bird abundance in eastern Texas. Southeastern Naturalist 3 (4):669-682.

Crozier, G. E., and D. E. Gawlik. 2003. Wading bird nesting effort as an index to wetland ecosystem integrity. Waterbirds 26 (3):303-324.

Cunningham, J . M., A. J . K. Calhoun, and W. E. Glanz. 2007. Pond-breeding amphibian species richness and habitat selection in a beaver-modified landscape. J ournal of Wildlife Management 71 (8):2517-2526. http:/ / dx.doi.org/ 10.2193/ 2006-510

DeLuca, W. V., C. E. Studds, L. L. Rockwood, and P. P. Marra. 2004. Influence of land use on the integrity of marsh bird communities of Chesapeake Bay, USA. Wetlands 24 (4):837-847.

Dykstra, C. R., J . L. Hays, F. B. Daniel, and M. M. Simon. 2001. Home range and habitat use of suburban Red-shouldered Hawks in southwestern Ohio. Wilson Bulletin 113 (3):308-316.

Edwards, N. T., and D. L. Otis. 1999. Avian communities and habitat relationships in South Carolina Piedmont beaver ponds. American Midland Naturalist 141(1):158-171.

Faccio, S. D. 2003. Postbreeding emigration and habitat use by J efferson and spotted salamanders in Vermont. J ournal of Herpetology 37 (3):479-489.

Fairbairn, S. E., and J . J . Dinsmore. 2001. Local and landscape-level influences on wetland bird communities of the prairie pothole region of Iowa, USA. Wetlands 21(1):41-47. 
Fletcher, R. J ., and R. R. Koford. 2003. Changes in breeding bird populations with habitat restoration in northern Iowa. American Midland Naturalist 150 (1):83-94.

Fowle, S. 2001. Guidelines for protecting spotted turtles and their habitats in Massachusetts. Westborough, MA: Natural Heritage and Endangered Species Program.

- 2001. Guidelines for protecting wood turtles and their habitats in Massachusetts. Westborough, MA: Natural Heritage and Endangered Species Program.

Francl, K. E., S. B. Castleberry, and W. M. Ford. 2004. Small mammal communities of high elevation central Appalachian wetlands. American Midland Naturalist 151(2):388-398.

Frey, S. N., and M. R. Conover. 2006. Habitat use by meso-predators in a corridor environment. J ournal of Wildlife Management 70 (4):1111-1118.

Gamble, L. R., K. McGarigal, D. B. Sigourney, and B. C. Timm. 2009. Survival and breeding frequency in marbled salamanders (Ambystoma opacum): Implications for spatio-temporal population dynamics. Copeia (2):394-407.

Golet, F. C., Y. Wang, J . S. Merrow, and W. R. DeRagon. 2001. Relationship between habitat and landscape features and the avian community of red maple swamps in southern Rhode Island. Wilson Bulletin 113 (2):217-227.

Graves, G. R. 2001. Factors governing the distribution of Swainson's warbler along a hydrological gradient in great dismal swamp. Auk 118 (3):650-664.

Hallworth, M., A. Ueland, E. Anderson, J . D. Lambert, and L. Reitsma. 2008. Habitat selection and site fidelity of Canada warblers (Wilsonia canadensis) in central New Hampshire. Auk 125 (4):880-888.

Hartwig, T. S., and E. Kiviat. 2007. Microhabitat association of blanding's turtles in natural and constructed wetlands in southeastern New York. J ournal of Wildlife Management 71(2):576-582.

Hocking, D. J ., T. A. G. Rittenhouse, B. B. Rothermel, J . R. J ohnson, C. A. Conner, E. B. Harper, and R. D. Semlitsch. 2008. Breeding and recruitment phenology of amphibians in Missouri oak-hickory forests. American Midland Naturalist 160 (1):41-60.

Kaminski, M. R., G. A. Baldassarre, and A. T. Pearse. 2006. Waterbird responses to hydrological management of Wetlands Reserve Program habitats in New York. Wildlife Society Bulletin 34 (4):921-926. http:// dx.doi.org/ 10.2193/ 00917648(2006)34[921:WRTHMO]2.0.CO;2

Knutson, M. G., G. J. Niemi, W. E. Neuton, and M. A. Friberg. 2004. Avian nest success in midwestern forests fragmented by agriculture. Condor 106 (1):116-130.

Laurent, E. J., and B. A. Kingsbury. 2003. Habitat separation among three species of water snakes in northwestern Kentucky. J ournal of Herpetology 37 (2):229-235. 
Litzgus, J . D., T. A. Mousseau, and M. J. Lannoo. 2004. Home range and seasonal activity of Southern Spotted Turtles (Clemmys guttata): Implications for management. Copeia 2004 (4):804-817. http:// dx.doi.org/ 10.1643/ CH-04024R1

Lor, S., and R. A. Malecki. 2006. Breeding ecology and nesting habitat associations of five marsh bird species in western New York. Waterbirds 29 (4):427-436.

Merola-Zwartjes, M., and J . P. DeLong. 2005. Avian species assemblages on on New Mexico golf courses: Surrogate riparian habitat for birds? Wildlife Society Bulletin 33 (2):435-447.

Metts, B. S., J . D. Lanham, and K. R. Russell. 2001. Evaluation of herpetofaunal communities on upland streams and beaver-impounded streams in the upper Piedmont of South Carolina. American Midland Naturalist 145 (1):54-65.

Montieth, K. E., and P. W. C. Paton. 2006. Emigration behavior of Spotted Salamanders on golf courses in southern Rhode Island. J ournal of Herpetology 40 (2):195205.

Moser, A. M., and J . T. Ratti. 2005. Value of riverine islands to nongame birds. Wildlife Society Bulletin 33 (1):273-284.

Naugle, D. E., K. F. Higgins, and S. M. Nusser. 1999. Effects of woody vegetation on prairie wetland birds. Canadian Field-Naturalist 113 (3):487-492.

Naugle, D. E., R. R. J ohnson, M. E. Estey, and K. F. Higgins. 2001. A landscape approach to conserving wetland bird habitat in the prairie pothole region of eastern South Dakota. Wetlands 21 (1):1-17.

Newbury, R. K., and T. A. Nelson. 2007. Habitat selection and movements of raccoons on a grassland reserve managed for imperiled birds. J ournal of Mammalogy 88 (4):1082-1089.

Oneal, B. J ., E. J . Heske, and J . D. Stafford. 2008. Waterbird response to wetlands restored through the conservation reserve enhancement program. J ournal of Wildlife Management 72 (3):654-664.

Paracuellos, M., and J . L. Telleria. 2004. Factors affecting the distribution of a waterbird community: The role of habitat configuration and bird abundance. Waterbirds $27(4): 446-453$.

Pearl, C. A., M. J . Adams, N. Leuthold, and R. B. Bury. 2005. Amphibian occurrence and aquatic invaders in a changing landscape: Implications for wetland mitigation in the Willamette Valley, Oregon, USA. Wetlands 25 (1):76-88.

Petranka, J . W., and C. T. Holbrook. 2006. Wetland restoration for amphibians: Should local sites be designed to support metapopulations or patchy populations? Restoration Ecology 14 (3):404-411.

Petranka, J. W., C. A. Kennedy, and S. S. Murray. 2003. Response of amphibians to restoration of a southern appalachian wetland: A long-term analysis of community dynamics. Wetlands 23 (4):1030-1042. 
Petranka, J. W., E. M. Harp, C. T. Holbrook, and J . A. Hamel. 2007. Long-term persistence of amphibian populations in a restored wetland complex. Biological Conservation 138 (3-4):371-380.

http://www.sciencedirect.com/science? ob=MImg\& imagekey=B6V5X4P127CC-2-

H\&_cdi $=5798 \&$ _ user $=930810 \&$ orig $=$ search\&_coverDate $=09 \% 2 \mathrm{~F} 30 \% 2 \mathrm{~F} 2007$ \& sk=998619996\&view=c\&wchp=dGLzVtb-

zSkzV\&md5=d391e633a9e782d2a5022e046b5afa99\&ie=/ sdarticle.pdf

Rehm, E. M., and G. A. Baldassarre. 2007. The influence of interspersion on marsh bird abundance in New York. Wilson J ournal of Ornithology 119 (4):648-654.

Rossell, C. R., J r., S. C. Patch, and S. P. Wilds. 2003. Attributes of Golden-Winged Warbler territories in a mountain wetland. Wildlife Society Bulletin 31 (4):10991104. http:// www.jstor.org/ stable/ 3784457

Russell, K. R., C. E. Moorman, J . K. Edwards, B. S. Metts, and D. C. Guynn. 1999. Amphibian and reptile communities associated with beaver (Castor canadensis) ponds and unimpounded streams in the Piedmont of South Carolina. J ournal of Freshwater Ecology 14 (2):149-158.

Snell-Rood, E. C., and D. A. Cristol. 2003. Avian communities of created and natural wetlands: bottomland forests in Virginia. The Condor 105 (2):303-315. http:// dx.doi.org/ 10.1650/ 0010-5422(2003)105[0303:ACOCAN]2.0.CO;2

Somers, A. B., J . Mansfield-J ones, and J . Braswell. 2007. In stream, streamside, and under stream bank movements of a bog turtle, Glyptemys muhlenbergii. Chelonian Conservation and Biology 6 (2):286-288.

Steen, D. A., J . P. Gibbs, and S. T. A. Timmermans. 2006. Assessing the sensitivity of wetland bird communities to hydrologic change in the Eastern Great Lakes Region. Wetlands 26 (2):605-611.

Twedt, D. J ., C. O. Nelms, V. E. Rettig, and S. R. Aycock. 1998. Shorebird use of managed wetlands in the Mississippi Alluvial Valley. The American Midland Naturalist 140 (1):140-152. http:/ / dx.doi.org/ 10.1674/ 00030031(1998)140[0140: SUOMWI]2.0.CO;2

Valiela, I., and P. Martinetto. 2007. Changes in bird abundance in eastern North America: Urban sprawl and global footprint? Bioscience 57 (4):360-370.

Vasconcelos, D., and A. J . K. Calhoun. 2004. Movement patterns of adult and juvenile Rana sylvatica (LeConte) and Ambystoma maculatum (Shaw) in three restored seasonal pools in Maine. J ournal of Herpetology 38 (4):551-561.

— 2006. Monitoring created seasonal pools for functional success: A six-year case study of amphibian responses, Sears Island, Maine, USA. Wetlands 26 (4):9921003.

Wilson, M. D., B. D. Watts, and D. F. Brinker. 2007. Status review of Chesapeake Bay marsh lands and breeding marsh birds. Waterbirds 30:122-137. 


\section{Appendix T: Wetland Mitigation Web Sites}

Arkansas Natural Resources Commission. Arkansas Wetland Mitigation Bank Program. http:// www.anrc.arkansas.gov/ WetlandMitBank.html. (accessed August 9, 2009)

California Coastal Commission. Procedural guidance for evaluating wetland mitigation projects in california's coastal zone: table of contents. http://www.coastal.ca.gov/ weteval/wetc.html. (accessed August 9, 2009)

DuPage County Illinois. DuPage County Stormwater Permits. http:// www.dupageco.org/ stormwater/ generic.cfm?doc_id=3499. (accessed August 9, 2009)

Indiana Department of Environmental Management. IDEM: Wetland Mitigation Monitoring. http:// www.in.gov/idem/4407.htm. (accessed August 9, 2009)

International Conference on Ecology and Transportation. International Conference on Ecology and Transportation Home Page. http:// www.icoet.net/index.asp. (accessed 2009)

King County Washington. Wetland Mitigation Banking Program. http:// www.kingcounty.gov/ operations/ policies/rules/ utilities/ put811pr.aspx. (accessed August 9, 2009)

Maryland Department of the Environment. Mitigation. http://www.mde.state.md.us/Programs/WaterPrograms/Wetlands_Waterwa ys/regulations/mitigation.asp. (accessed August 9, 2009)

Michigan Department of Environmental Quality. DEQ - Local Wetland Regulations. http://www.michigan.gov/ deq/0,1607,7-135-3313_3687-24312--,00.html. (accessed August 9, 2009)

DEQ - Wetland Mitigation. http:// www.michigan.gov/ deq/ 0,1607,7-1353313_3687-86447--,00.html. (accessed August 9, 2009)

Missouri Department of Natural Resources. 401 Water Quality Certification. http:// www.dnr.mo.gov/ env/ wpp/ 401/ . (Accessed August 09, 2009)

National Center for Manufacturing Sciences. Wetlands Information Resource Locator. http:// www.envcap.org/ statetools/ swift/ swift.html. (Accessed August 9, 2009)

National Oceanic and Atmospheric Administration Fisheries Service. National Wetlands Action Plan, Clean Water Act Section 404 Mitigation Guidance Directory. http:// www.mitigationactionplan.gov/links.html. (Accessed 2009)

- NOAA Fisheries Northeast Regional Office - Habitat Socio-Economics Programs: Mitigataion Calculator. http:// www.nero.noaa.gov/ hcd/ socio/MitigationCalculator.htm. (accessed August 9, 2009) 
New Hampshire Department of Environmental Services. Welcome - Wetland Mitigation Program - Wetlands Bureau - NH Department of Environmental Services. http:// des.nh.gov/ organization/ divisions/ water/ wetlands/wmp/index.htm. (accessed August 9, 2009)

NewJ ersey Department of Environmental Protection. NJ DEP Land Use Regulation Program (DLUR) - Mitigation - Mitigation Ratios. http:// www.nj.gov/dep/landuse/ mratios.html. (accessed August 9, 2009)

New York State Department of Environmental Conservation. Freshwater Wetlands Permit Program: Standards for Issuance - NYS Dept. of Environmental Conservation. http:// www.dec.ny.gov/ permits/ 6273.html. (accessed August 9, 2009)

Oregon Department of State Lands. Wetlands/Waterways Removal-Fill Do You Want to Be a Mitigation Banker? http:// oregonstatelands.us/DSL/ PERMITS/mit_banker.shtml. (accessed August 9, 2009)

Siragusa, K. S. 2008. Integrating a watershed approach into Clean Water Act Section 404, wetland and stream compensatory mitigation lessons learned and recommendations for Georgia. Internet Resource; Archival Material Date of Entry: 20090824. (Accessed August 24, 2009) http:// purl.galileo.usg.edu/ uga\%5Fetd/ siragusa\%5Fkelly\%5F200805\%5Fms

Tampa Bay Water. Wetland Mitigation.

http:// www.tampabaywater.org/programs/mitigation.aspx. (accessed August 09, 2009)

Thompson, J . W. J . N. S. S. 2008. The federal wetland permitting program avoidance and minimization requirements.

http://www.elistore.org/ reports_detail.asp?ID=11275\&topic=wetlands. [Internet Resource; Computer File Date of Entry: 20080409]. Washington, DC: Environmental Law Institute 2008 (Accessed August 24, 2009).

Virginia Department of Environmental Quality. Virginia DEQ - Wetlands - Mitigation. http:// www.deq.state.va.us/ wetlands/mitigate.html. (accessed August 9, 2009)

Virginia Marine Resources Commission. Regulation: Wetlands mitigation-compensation policy and supplemental guidelines.

http:/ / www.mrc.virginia.gov/ Regulations/ fr390.shtm. (accessed August 9, 2009)

Washington State Department of Transportation. Wetland Mitigation. http:/ / www.wsdot.wa.gov/ Environment/ Biology/ Wetlands/ mitigation.htm. (accessed August 9, 2009)

Washington State Department of Transportation (WSDOT). 2008. Wetland and Buffer Impact Assessment Guidance: Washington State Department of Transportation http:/ / www.wsdot.wa.gov/NR/ rdonlyres/ D0FE60A8-A193-4615-A68427E66CFBFB61/ 0/ WetMitBuffImpAssess.pdf. 
Wisconsin Department of Natural Resources. Proposed Rules for Wetland Compensatory Mitigation in Wisconsin.

http://dnr.wi.gov/wetlands/mitigation/documents/training_030402_pp_reg ulations.pdf. (accessed August 9, 2009)

—. Wetland Compensatory Mitigation - WDNR.

http:// www.dnr.state.wi.us/ wetlands/ mitigation/ . (accessed August 9, 2009) 


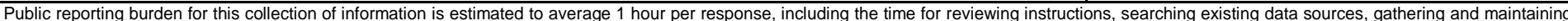

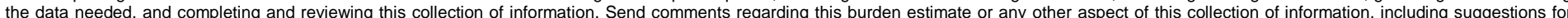

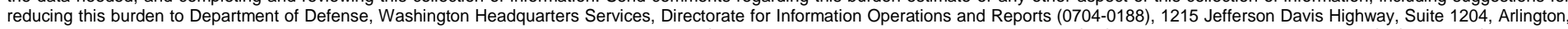

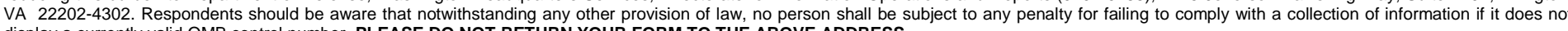
display a currently valid OMB control number. PLEASE DO NOT RETURN YOUR FORM TO THE ABOVE ADDRESS.

\begin{tabular}{l|c}
$\begin{array}{l}\text { 1. REPORT DATE (DD-MM-YYYY) } \\
\text { July } 2011\end{array}$ & $\begin{array}{c}\text { 2. REPORT TYPE } \\
\text { Final report }\end{array}$ \\
\hline
\end{tabular}

\section{TITLE AND SUBTITLE}

A Bibliography of Selected Literature on Indirect Impacts Associated with Clean Water Act Section 404 Permits

\section{DATES COVERED (From - To)}

5a. CONTRACT NUMBER

5b. GRANT NUMBER

5c. PROGRAM ELEMENT NUMBER

\section{AUTHOR(S)}

5d. PROJECT NUMBER

Timothy C. Wilder, William M. Ford, and Marie M. Perkins

5e. TASK NUMBER

\section{5f. WORK UNIT NUMBER}

\section{PERFORMING ORGANIZATION NAME(S) AND ADDRESS(ES)}

8. PERFORMING ORGANIZATION REPORT

U.S. Army Engineer Research and Development Center

Environmental Laboratory NUMBER

3909 Halls Ferry Road

Vicksburg, MS 39180-6199

9. SPONSORING I MONITORING AGENCY NAME(S) AND ADDRESS(ES)

ERDC/EL TR-11-6

10. SPONSOR/MONITOR'S ACRONYM(S)

11. SPONSOR/MONITOR'S REPORT NUMBER(S)

\section{DISTRIBUTION / AVAILABILITY STATEMENT}

Approved for public release; distribution is unlimited.

\section{SUPPLEMENTARY NOTES}

\section{ABSTRACT}

This report summarizes a review of the scientific literature from the year 2000 to the present that characterizes indirect impacts associated with Clean Water Act Section 404 permits. Also of interest was literature from 2004 forward that addresses compensatory mitigation for impacts, particularly with respect to current policy.

Literature containing derivations of the search terms “Clean Water Act," “404,” "temporary fill," “dredge and fill,” "impact,” "secondary impact," and "cumulative impact” in the title, keyword or abstract field(s) was selected. When these searches produced few results, the number of search terms was expanded. This series of searches returned in excess of 5,500 bibliographic records. Each record's abstract was then reviewed for relevance to the Corps of Engineer's 404 permitting program and assigned to at least one of 20 groups according to the focus of that particular study. A review for relevance and assignment to groups reduced the number of records to 1,252 (approximately $10 \%$ of which were assigned to more than one group).

\section{SUBJECT TERMS}

Bibliography

Clean Water Act
Compensatory mitigation

Indirect impact
Section 404 permits

\section{SECURITY CLASSIFICATION OF:}

a. REPORT

UNCLASSIFIED

b. ABSTRACT
UNCLASSIFIED

c. THIS PAGE

UNCLASSIFIED
17. LIMITATION OF ABSTRACT

\section{NUMBER OF PAGES}

137 19a. NAME OF RESPONSIBLE PERSON

19b. TELEPHONE NUMBER (include area code) 